\title{
Multi-stage Reactive Formation of Troctolites in Slow-spreading Oceanic Lithosphere (Erro-Tobbio, Italy): a Combined Field and Petrochemical Study
}

\author{
Valentin Basch ${ }^{1}$, Elisabetta Rampone ${ }^{1 *}$, Laura Crispini ${ }^{1}$, \\ Carlotta Ferrando ${ }^{2 \dagger}$, Benoit Ildefonse ${ }^{2}$ and Marguerite Godard ${ }^{2}$
}

1DISTAV, Università degli Studi di Genova, Corso Europa 26, Genova I-16132, Italy; ${ }^{2}$ Géosciences Montpellier, University of Montpellier, CNRS, 34095 Montpellier cedex 05, France

*Corresponding author. E-mail: betta@dipteris.unige.it

Present address: CRPG, University of Lorraine, 54501 Vandoeuvre-les-Nancy, France.

Received June 21, 2018; Accepted March 19, 2019

\begin{abstract}
Many recent studies have investigated the replacive formation of troctolites from mantle protoliths and the compositional evolution of the percolating melt during melt-rock interaction processes. However, strong structural and geochemical constraints for a replacive origin have not yet been established. The Erro-Tobbio impregnated mantle peridotites are primarily associated with a hectometre-size troctolitic body and crosscutting gabbroic dykes, providing a good field control on melt-rock interaction processes and subsequent magmatic intrusions. The troctolitic body exhibits high inner complexity, with a host troctolite (Troctolite A) crosscut by a second generation of troctolitic metre-size pseudo-tabular bodies (Troctolite B). The host Troctolite A is characterized by two different textural types of olivine, corroded deformed millimetre- to centimetre-size olivine and fine-grained rounded undeformed olivine, both embedded in interstitial to poikilitic plagioclase and clinopyroxene. Troctolite A shows melt-rock reaction microstructures indicative of replacive formation after percolation and impregnation of mantle dunites by a reactive melt. The evolution of the texture and crystallographic preferred orientation (CPO) of olivine are correlated and depend on the melt/rock ratio involved in the impregnation process. A low melt/rock ratio allows the preservation of the protolith structure, whereas a high melt/rock ratio leads to the disaggregation of the pre-existing matrix. The mineral compositions in Troctolite A define reactive trends, indicative of the buffering of the melt composition by assimilation of olivine during impregnation. The magmatic Troctolite $B$ bodies are intruded within the pre-existing Troctolite $A$ and are characterized by extreme textural variations of olivine, from decimetre-size dendritic to fine-grained euhedral crystals embedded in poikilitic plagioclase. This textural variability is the result of olivine assimilation during melt-rock reaction and the correlated increase in the degree of undercooling of the percolating melt. In the late gabbroic intrusions, mineral compositions are consistent with the fractional crystallization of melts modified after the reactive crystallization of Troctolites A and B. The ErroTobbio troctolitic body has a multi-stage origin, marked by the transition from reactive to fractional crystallization and diffuse to focused melt percolation and intrusion, related to progressive exhumation. During the formation of the troctolitic body, the melt composition was modified and controlled by assimilation and concomitant crystallization reactions occurring at low melt supply. Similar processes have been described in ultraslow-spreading oceanic settings characterized by scarce magmatic activity.
\end{abstract}




\section{INTRODUCTION}

Recent studies have demonstrated that melt-rock interactions can lead to extensive small-scale structural and geochemical heterogeneities within percolated mantle peridotites at different depths (e.g. Quick, 1981, 1982; Dijkstra et al., 2002, 2003; Lissenberg \& Dick, 2008; Soustelle et al., 2009, 2010, 2014; Collier \& Kelemen, 2010; Higgie \& Tommasi, 2012, 2014; Tursack \& Liang, 2012; Saper \& Liang, 2014; Dygert et al., 2016; Paquet et al., 2016; Renna et al., 2016; Sanfilippo et al., 2017), and can act as a rock-forming process for replacive lithotypes. In extensional settings worldwide, spinel harzburgites and spinel dunites showing decoupled bulkrock and mineral chemistry have been interpreted as the replacive products of open-system reactive melt percolation at spinel-facies depths, driven by pyroxene dissolution and olivine crystallization (e.g. Takazawa et al., 1992; Godard et al., 1995; Kelemen et al., 1995a, 1995b, 2000, 2007; Rampone et al., 2004, 2008; Piccardo et al., 2007; Dick et al., 2008, 2010; Rampone \& Borghini, 2008; Lambart et al., 2009; Liang et al., 2011; Pirard et al., 2013; Dygert et al., 2016). In contrast, plagioclaserich peridotites have been ubiquitously found in ophiolitic and oceanic settings and interpreted as the replacive product of melt impregnation that occurred at shallower plagioclase-facies conditions, leading to olivine dissolution and interstitial plagioclase and pyroxene crystallization (e.g. Van der Wal \& Bodinier, 1996; Garrido \& Bodinier, 1999; Dijkstra et al., 2002, 2003; Borghini et al., 2007; Rampone \& Borghini, 2008; Tursack \& Liang, 2012; Saper \& Liang, 2014; Basch et al., 2018).

Melt-rock interaction has also been increasingly invoked in the formation of the oceanic crust and described as a key geochemical process in the compositional evolution of percolating mid-ocean ridge basalt (MORB) melts, based on several lines of evidence: (1) dissolution-precipitation microstructures and geochemical zoning in lower crustal gabbros (Lissenberg \& Dick, 2008; Lissenberg et al., 2013; Lissenberg \& MacLeod, 2016); (2) the composition of melt inclusions in lava phenocrysts (Laubier et al., 2014; Coumans et al., 2016); (3) peculiarities in the compositional variations of MORB, not consistent with a process of fractional crystallization alone (Collier \& Kelemen, 2010; Van den Bleeken et al., 2011; Paquet et al., 2016; Sanfilippo et al., 2016a); (4) the structural and geochemical mantle inheritance inferred in olivine-rich troctolites enclosed in the lowermost oceanic crust. These olivinerich gabbroic rocks are thought to represent the replacive product of the interaction between a dunitic matrix and a percolating tholeiitic melt in disequilibrium with its host-rock (Lissenberg \& Dick, 2008; Suhr et al., 2008; Drouin et al., 2009, 2010; Renna \& Tribuzio, 2011; Higgie
\& Tommasi, 2012; Sanfilippo \& Tribuzio, 2013; Sanfilippo et al., 2013, 2014, 2015a, 2016b; Rampone et al., 2016; Basch, 2018; Basch et al., 2018; Ferrando et al., 2018). However, during the dissolution-precipitation reaction, the texture of the olivine matrix progressively evolves towards the cumulate-like poikilitic texture of an olivine-rich gabbroic rock (Suhr et al., 2008; Drouin et al., 2010; Basch et al., 2018), thus calling for strong structural and geochemical constraints to discriminate between a magmatic and a replacive origin of the lithotype.

Previous studies have documented that the AlpineApennine ophiolitic peridotites record various stages of melt-rock interaction occurring at different mantle depths (e.g. Rampone \& Borghini, 2008; Piccardo \& Guarnieri, 2010; Rampone et al., 2018). In the ErroTobbio ultramafic unit (Voltri Massif, Ligurian Alps), peridotites preserve microstructures and geochemical compositions indicative of a multi-stage melt-rock interaction history, related to progressive exhumation of this mantle sector from spinel-facies depths to shallow oceanic environments (Rampone et al., 2004, 2005, 2016; Borghini \& Rampone, 2007; Borghini et al., 2007; Piccardo \& Vissers, 2007; Rampone \& Borghini, 2008). In places, impregnated plagioclase peridotites are found in irregular contact with a hectometre-size troctolitic body, later crosscut by troctolitic and gabbroic dykes. Previous studies have inferred a prevalent magmatic origin for these gabbroic rocks (Borghini \& Rampone, 2007; Borghini et al., 2007; Rampone \& Borghini, 2008). In a recent study on the geochemistry of olivine, Rampone et al. (2016) highlighted the important role of melt-rock interaction in the origin of olivinerich troctolites. The Erro-Tobbio peridotite-gabbro association thus appears an ideal case study to track the structural and geochemical changes in mantle peridotites progressively transforming to replacive troctolites during reactive dissolution (i.e. a dissolution-precipitation process; Liang, 2003), and to identify the role of reactive versus fractional crystallization in the origin of olivine-bearing gabbroic rocks. In this study, we present detailed field mapping of the internal structural complexity of the troctolitic body, coupled with electron backscatter diffraction (EBSD) measurements, and mineral major element analyses [by electron probe microanalyser (EPMA)] of the host spinel and plagioclase peridotite, the troctolitic body, and the gabbroic intrusions.

Major outcomes of this work are (1) a documented correlation between the textural evolution of the olivine matrix and the modification of the olivine crystallographic preferred orientation (CPO) during replacive formation of the olivine-rich troctolite and (2) the demonstrated modification of the melt composition during 
the melt-rock interaction history, leading to peculiar mineral compositional trends in the gabbroic intrusions, shifted towards Mg-rich olivines and clinopyroxenes.

\section{STRUCTURAL AND PETROLOGICAL BACKGROUND}

The Alpine-Apennine ophiolites are predominantly constituted by mantle peridotites and represent lithospheric analogues of ocean-continent transition zones and slow- to ultraslow-spreading environments (Rampone et al., 1997, 2004, 2008; Rampone \& Piccardo, 2000; Müntener \& Piccardo, 2003; Müntener et al., 2004; Piccardo et al., 2004; Borghini et al., 2007; Manatschal \& Müntener, 2009). They are thought to represent the lithospheric remnants of the narrow Jurassic Ligurian Tethys oceanic basin, opened by passive lithosphere extension and breakup of the continental lithosphere, leading to slow-spreading oceanization (Rampone \& Piccardo, 2000; Manatschal \& Müntener, 2009).

The Erro-Tobbio ultramafic body (Voltri Massif, Ligurian Alps, Fig. 1) exposes kilometre-scale unaltered peridotites, mostly devoid of any Alpine overprint (Bezzi \& Piccardo, 1971; Chiesa et al., 1975; Ernst \& Piccardo, 1979; Ottonello et al., 1979; Hoogerduijn-Strating et al., 1990, 1993; Piccardo et al., 1990, 1992, 2004; Scambelluri et al., 1991; Vissers et al., 1991; Borsi et al., 1996; Capponi et al., 1999; Rampone et al., 2004, 2005), allowing the study of the pre-Alpine structural and chemical mantle evolution. The Erro-Tobbio unit is mostly made of variably serpentinized spinel-bearing Iherzolites and harzburgites. Previous petrological and structural studies documented a tectono-metamorphic decompressional evolution of these mantle rocks, from deep lithospheric settings $(P>15-20 \mathrm{kbar})$ to shallow depths $(P<5 \mathrm{kbar})$, with a progressive re-equilibration from spinel- to plagioclase- to amphibolite-facies conditions (Hoogerduijn-Strating et al., 1990, 1993; Vissers et al., 1991; Rampone et al., 2005), and the development of extensional shear zones forming spinel tectonites, plagioclase-, hornblende- and chlorite-bearing mylonites, and serpentinite mylonites (Hoogerduijn-Strating et al., 1993). This extension-related exhumation was accompanied by multiple episodes of melt percolation and intrusion, specifically: (1) a first open-system olivine-saturated reactive porous flow at spinel-facies conditions, leading to the dissolution of mantle clinopyroxene and orthopyroxene, and crystallization of olivine; (2) a melt-rock reaction at plagioclase-facies conditions $(<8-10 \mathrm{kbar})$ leading to the formation of plagioclase-bearing impregnated peridotites, by dissolution of olivine and crystallization of plagioclase \pm opx $\pm \mathrm{cpx}$; (3) multiple episodes of gabbroic intrusions at shallow depths $(P<5 \mathrm{kbar})$ (Piccardo et al., 2004; Rampone et al., 2004, 2005, 2014, 2016, 2018; Borghini \& Rampone, 2007; Borghini et al., 2007; Piccardo \& Vissers, 2007; Rampone \& Borghini, 2008). Geochronological studies on gabbroic rocks from the
Alpine-Apennine ophiolites indicate a large time span of gabbroic intrusion ( 20 Myr) in the Alpine Tethys (Rampone et al., 2014, and references therein). The Erro-Tobbio gabbroic intrusions yield the oldest Sm$\mathrm{Nd}$ age of the crustal gabbroic sequences within the Alpine-Apennine ophiolites with an age of $178 \pm 5 \mathrm{Ma}$ (Rampone et al., 2014), therefore representing early melt intrusions in thinned lithospheric mantle exhumed at ocean-continent transition domains (Rampone \& Piccardo, 2000; Manatschal \& Müntener, 2009).

In the southeastern part of the Erro-Tobbio peridotite, the impregnated mantle peridotites are in irregular contact with a hectometre-size troctolitic body, previously described as a primitive cumulate body (Fig. 1; Borghini et al., 2007; Borghini \& Rampone, 2007; Rampone \& Borghini, 2008; Rampone et al., 2016). Gabbroic dykes crosscut all mantle structures, as well as the troctolitic body-impregnated peridotite contact (Borghini et al., 2007). Rampone et al. (2016) recently demonstrated the important effect of olivine-dissolving, plagioclase-crystallizing melt-rock interaction on the Erro-Tobbio troctolitic body mineral compositions. This leads to significant enrichments in specific trace elements [ $\mathrm{Zr}, \mathrm{Hf}, \mathrm{Ti}$, heavy rare earth elements (HREE)], coupled with strong high field strength element (HFSE)REE fractionation in olivine.

Previous geochemical studies documented a significant change in the melt composition between the impregnation event observed in the plagioclase peridotites (Rampone et al., 2005) and the late troctolite-gabbro intrusions. Impregnating melts had an orthopyroxene-saturated light REE (LREE)-depleted signature, consistent with single depleted melt increments produced by near-fractional melting of a MORB-type asthenospheric mantle source (Piccardo et al., 2004; Borghini et al., 2007; Rampone \& Borghini, 2008). A similar origin has been inferred for other AlpineApennine impregnated peridotites (e.g. Rampone et al., 1997, 2008, 2018; Piccardo et al., 2007). On the other hand, parental melts to the troctolitic body and late gabbroic discrete intrusions resemble normal (N)-MORBtype aggregated melts (Rampone et al., 1998, 2014, 2016; Borghini \& Rampone, 2007; Borghini et al., 2007; Rampone \& Borghini, 2008). Based on available time constraints on the extensional evolution of the ErroTobbio mantle (i.e. the Permian age of plagioclasefacies recrystallization documented in impregnated peridotite mylonites; Rampone et al., 2005), and the Jurassic age of the gabbroic intrusions (Rampone et al., 2014), melt impregnation in the plagioclase peridotites and subsequent troctolite-gabbro intrusion events were probably uncorrelated.

\section{FIELD RELATIONSHIPS}

The investigated area exposes a $500 \mathrm{~m}$ wide ultramafic body surrounded by serpentinized high-pressure, lowtemperature Alpine shear zones. The ultramafic body preserves a pre-Alpine mantle history, displaying an 

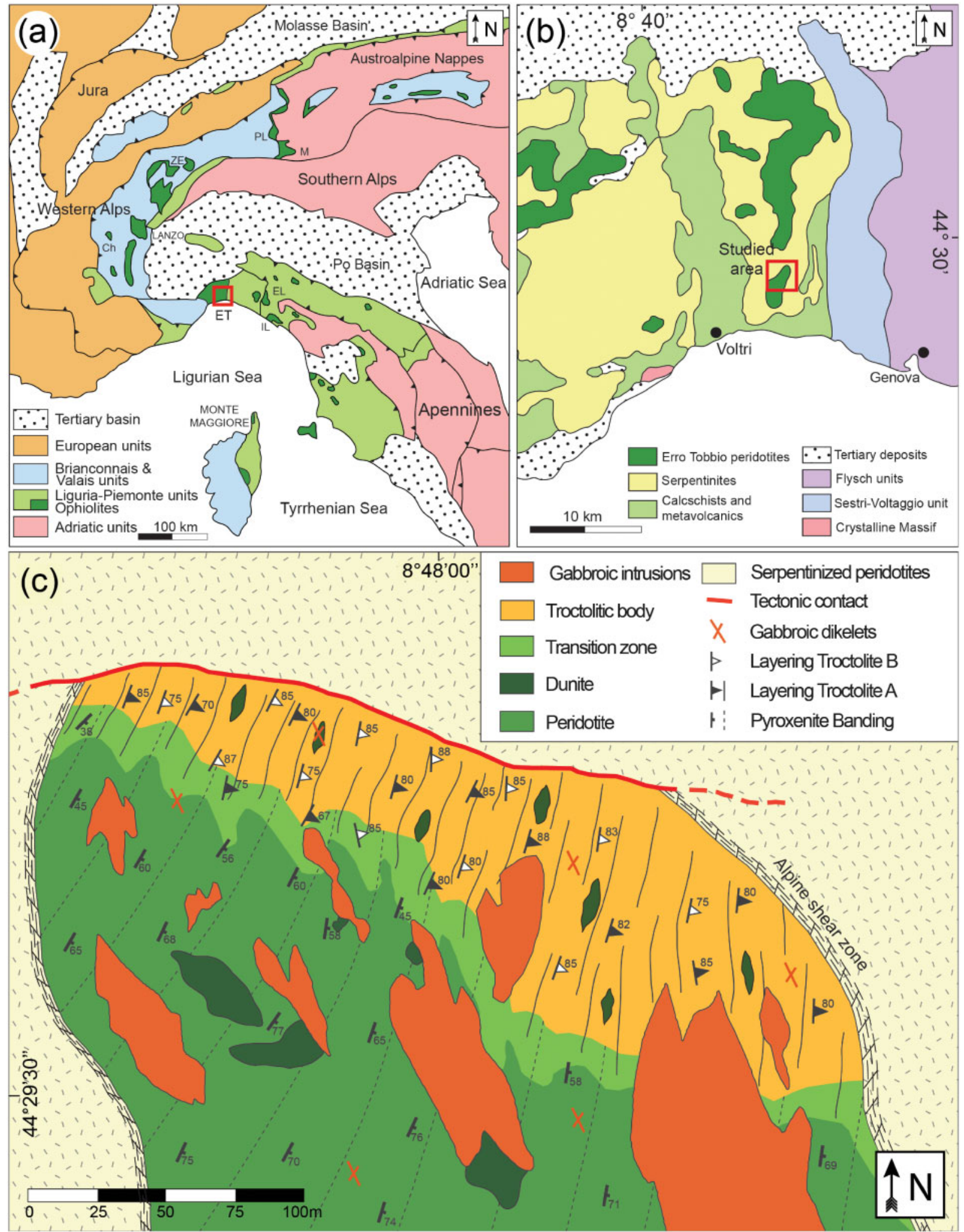

Fig. 1. (a) Sketch map of the Northern Apennines and Western Alps (redrawn after Piccardo \& Vissers, 2007). The red square indicates the location of the Voltri Massif, in the Ligurian Alps. PL, Platta; M, Malenco; ZE, Zermatt; Ch, Chenaillet; ET, Erro-Tobbio; EL, External Ligurides; IL, Internal Ligurides. (b) Map of the Voltri Massif and location of the studied area within the Erro-Tobbio peridotites (redrawn after Piccardo \& Vissers, 2007). (c) Geological map of the Mt. Foscallo area, in the Erro-Tobbio peridotites. This structural map merges new data measured in the field with previously published data from Borghini et al. (2007) and Borghini \& Rampone (2007). 
association between mantle peridotites and ultramaficmafic bodies and intrusions (from plagioclase wehrlites to troctolites to olivine gabbros) (Fig. 1; Borghini \& Rampone, 2007; Borghini et al., 2007; Rampone \& Borghini, 2008; Rampone et al., 2016).

Mantle peridotites are plagioclase-bearing Iherzolites showing in places a weak tectonic foliation defined by ortho- and clinopyroxene shape-preferred orientations. They are primarily associated with metresize dunitic pods and centimetre-size pyroxenite layers showing a constant NNE-SSW orientation and strongly dipping to the east (Fig. 1). In the northernmost part of the ultramafic body, the plagioclase Iherzolites are in irregular contact with a hectometre-size troctolitic body. The contact is marked by the occurrence of troctolitic and plagioclase-bearing wehrlite apophyses into the mantle peridotites, crosscutting the pyroxenite banding (Borghini \& Rampone, 2007; Borghini et al., 2007; Rampone \& Borghini, 2008; Rampone et al., 2016). Detailed mapping and sampling in selected outcrops has revealed that the inner troctolitic body is characterized by a high modal compositional variability, from plagioclase wehrlite to troctolite to dunite, and a structural complexity characterized by different generations of troctolite showing crosscutting relationships and highly variable olivine textures. In the following, based on these structural criteria, we distinguish different types of troctolites within the mafic body.

Troctolite $A$ is in irregular contact with the mantle peridotites through a transition zone (Fig. 1) characterized by plagioclase Iherzolites with decimetre-thick crosscutting troctolite and plagioclase-bearing wehrlite apophyses (Fig. 2a) in which it is difficult to easily distinguish the different lithologies (Fig. 1). Troctolite A shows variable olivine modal contents (from 55 to 74 vol. \%; Table 1, Fig. $2 \mathrm{~b}$ and c) and interstitial plagioclase \pm clinopyroxene, and it includes decimetre-size dunitic pods (Fig. 2d). The modal composition variability between olivine-rich and plagioclase-rich troctolite forms a local subvertical decimetre-size layering, showing a NNW-SSW orientation, dipping to the east (Figs 1 and $2 \mathrm{~b}$ ).

Troctolite B occurs as decimetre- to metre-size pseudo-tabular elongated bodies crosscutting the layering of plagioclase enrichment in Troctolite A (Figs 2c and $3 a$ ), and showing irregular to sharp contacts with the host troctolite (Figs 2c and 3a, b). Troctolite B bodies display extreme olivine textural variations at the scale of a few centimetres, from millimetre-size euhedral olivine crystals to centimetre- and decimetre-size hopper and dendritic olivine crystals (Fig. 3c-e). The olivine textural layering observed in Troctolite B, between granular and dendritic portions of the pseudo-tabular bodies (Fig. 3e), has a NNE-SSW strike and dips steeply to the east, similar to the plagioclase enrichment layering in Troctolite A (Fig. 1).

The peridotites and troctolitic bodies are both intruded by decametre-size gabbroic intrusions, centimetre- to metre-thick troctolitic to olivine gabbro dykes and centimetre-thick dykelets, all striking NNWSSE, and dipping to the east $\left(40-50^{\circ}\right.$; Figs 1 and 2a; Borghini \& Rampone, 2007; Borghini et al., 2007), although in places dykelets occur as conjugate pairs. Dykes and dykelets are in straight and sharp contact with the host-rock and show no chilled margins. They display a grain-size variability, from fine grained towards the margin of the intrusion (millimetre-size crystals), to coarse grained (centimetre-size crystals) in the core of the dyke. Figure 4 summarizes the field relationships mapped in the studied Erro-Tobbio ultramafic body, between plagioclase Iherzolites, Troctolite A, Troctolite $B$, and gabbroic intrusions.

\section{SAMPLING AND ANALYTICAL METHODS}

We used samples of spinel Iherzolites, plagioclase lherzolites, troctolites and gabbroic intrusions collected during previous petrological investigations of the studied area (Fig. 1; Rampone et al., 2004, 2005, 2014, 2016; Borghini \& Rampone, 2007; Borghini et al., 2007), as well as newly collected samples of troctolite and gabbroic intrusions. The spinel and plagioclase Iherzolites were sampled from a location near the troctolitic body, where the alteration is much less developed than elsewhere within the Erro-Tobbio peridotites. These samples were used as a structural and chemical reference for the mantle protolith prior to the formation of the troctolitic body and gabbroic dykes. Table 1 reports the modal composition of the 40 studied samples, namely three spinel Iherzolites, four plagioclase Iherzolites, 11 Troctolites $A$, one dunite pod, five wehrlite and troctolite apophyses, 10 Troctolites $B$, and six troctolitic to olivine gabbro intrusions. We performed structural EBSD mapping of all samples, and mineral major (EPMA) element chemical analyses of 24 samples, including two spinel Iherzolites, two plagioclase Iherzolites, seven Troctolites $A$, one dunite pod, two wehrlite and troctolite apophyses, five Troctolites $B$, and five troctolitic to olivine gabbro intrusions. Detailed methods for EBSD and mineral major element analyses can be found in the Supplementary Data; supplementary data are available for downloading at http://www.pet rology.oxfordjournals.org.

\section{PETROGRAPHY}

\section{Spinel Iherzolites}

These show protogranular to porphyroclastic assemblages of olivine, orthopyroxene, clinopyroxene and spinel. Olivine and pyroxenes (orthopyroxene + clinopyroxene) are deformed, and display kink bands and undulatory extinction, respectively. Clinopyroxenes and orthopyroxenes both show thin exsolution lamellae of the complementary pyroxene. Spinels are found as granular grains in the Iherzolitic matrix and in orthopyroxene + spinel symplectites at the rim of orthopyroxene porphyroclasts, previously described as an effect of 

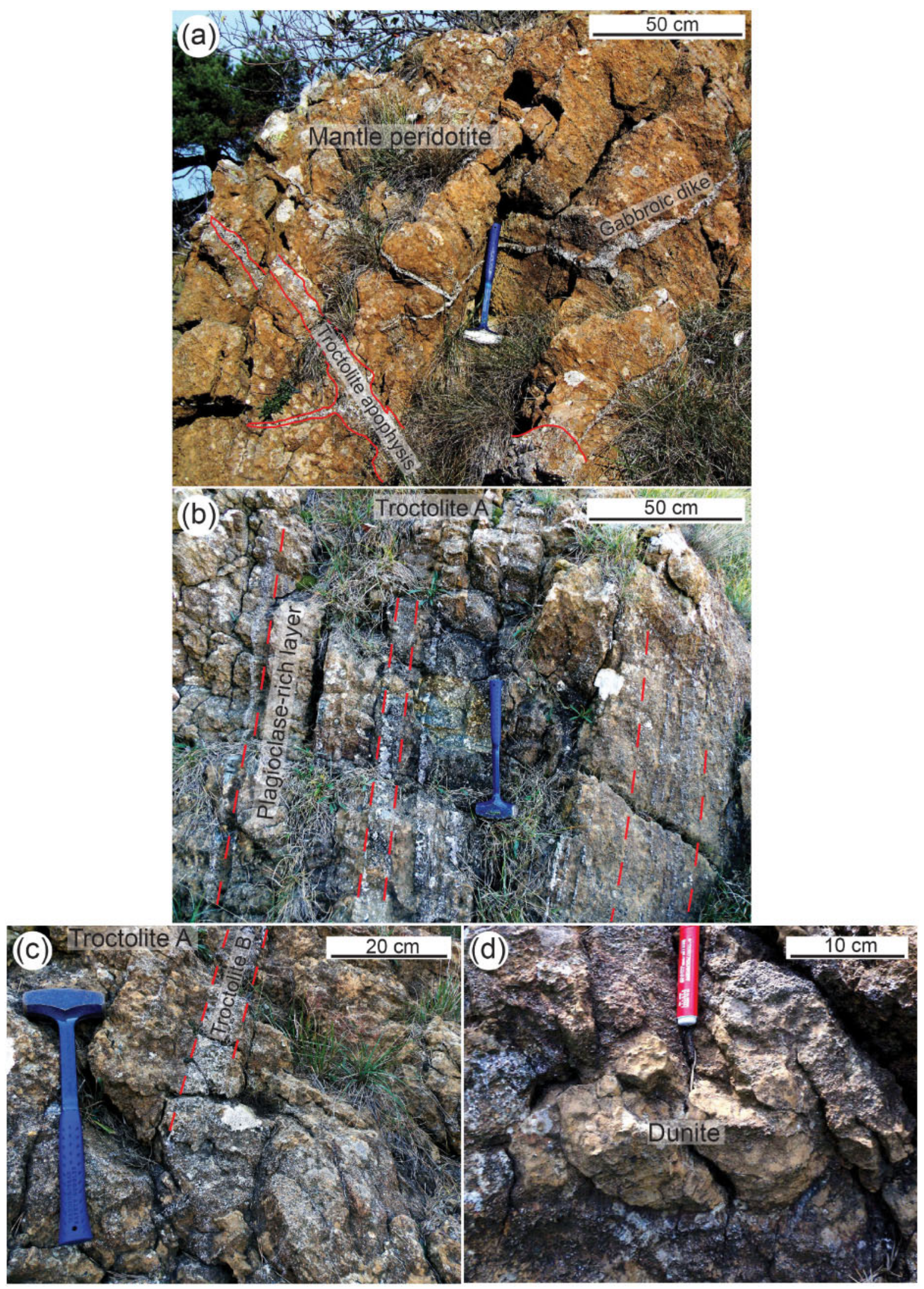

Fig. 2. Troctolite A field structures. (a) Troctolite apophysis within the mantle peridotites at the contact between the troctolitic body and the peridotites ('transition zone'), and gabbroic dyke crosscutting the association between peridotites and troctolites. (b) Plagioclase-rich layering within the host Troctolite A. (c) Crosscutting relationship between Troctolite A and Troctolite B. (d) Dunitic pod included within Troctolite A. 
Table 1: Studied samples, lithotype, modal composition, and PfJ olivine

\begin{tabular}{|c|c|c|c|c|c|c|c|c|}
\hline \multirow[t]{2}{*}{ Sample } & \multirow[t]{2}{*}{ Lithotype } & \multicolumn{4}{|c|}{ Modal compositions } & \multicolumn{3}{|c|}{ PfJ olivine } \\
\hline & & Olivine & Plagio & Cpx & Opx & {$[100]$} & {$[010]$} & [001] \\
\hline $\begin{array}{l}\text { ETR2* } \\
\text { ETR4B* } \\
\text { ETR4A* } \\
\text { P1B* } \\
\text { P1A* } \\
\text { P1* } \\
\text { MF40* }\end{array}$ & $\begin{array}{l}\text { Spinel Iherzolite } \\
\text { Spinel Iherzolite } \\
\text { Spinel Iherzolite } \\
\text { Plagio. Iherzolite } \\
\text { Plagio. Iherzolite } \\
\text { Plagio. Iherzolite } \\
\text { Plagio. Iherzolite }\end{array}$ & $\begin{array}{l}78 \\
75 \\
71 \\
57 \\
56 \\
55 \\
53\end{array}$ & $\begin{array}{r}0 \\
0 \\
0 \\
10 \\
10 \\
12 \\
5 \\
\end{array}$ & $\begin{array}{r}7 \\
5 \\
14 \\
11 \\
4 \\
11 \\
12\end{array}$ & $\begin{array}{l}15 \\
20 \\
15 \\
22 \\
30 \\
22 \\
30\end{array}$ & $\begin{array}{l}2.33 \\
2.24 \\
2.08 \\
2.12 \\
1.90 \\
2.53 \\
2.07 \\
\end{array}$ & $\begin{array}{l}2.84 \\
1.64 \\
1.65 \\
3.61 \\
2.67 \\
4.17 \\
3.13 \\
\end{array}$ & $\begin{array}{l}2.02 \\
1.56 \\
1.32 \\
1.50 \\
1.40 \\
2.23 \\
1.63 \\
\end{array}$ \\
\hline $\begin{array}{l}\text { MF104A } \\
\text { MF21* } \\
\text { MF15* } \\
\text { MF97 } \\
\text { MF51* } \\
\text { MF7A1* } \\
\text { MF7A2* } \\
\text { MF7C1* } \\
\text { MF51A1* } \\
\text { MF51A2* } \\
\text { MF96A } \\
\text { MF96B } \\
\text { MF102A1 } \\
\text { MF102B1 } \\
\text { MF47A* } \\
\text { MF47B* } \\
\text { MF102A2 } \\
\end{array}$ & $\begin{array}{l}\text { Dunite } \\
\text { Troctolite A } \\
\text { Troctolite A } \\
\text { Troctolite A } \\
\text { Troctolite apophysis } \\
\text { Troctolite A } \\
\text { Troctolite A } \\
\text { Troctolite A } \\
\text { Troctolite apophysis } \\
\text { Troctolite apophysis } \\
\text { Troctolite A } \\
\text { Troctolite A } \\
\text { Troctolite A } \\
\text { Troctolite A } \\
\text { Wehrlite apophysis } \\
\text { Wehrlite apophysis } \\
\text { Troctolite A } \\
\end{array}$ & $\begin{array}{l}97 \\
74 \\
68 \\
68 \\
67 \\
66 \\
65 \\
65 \\
65 \\
64 \\
60 \\
61 \\
60 \\
60 \\
60 \\
59 \\
55\end{array}$ & $\begin{array}{r}0 \\
15 \\
31 \\
30 \\
32 \\
23 \\
26 \\
27 \\
32 \\
35 \\
39 \\
37 \\
36 \\
36 \\
19 \\
13 \\
40 \\
\end{array}$ & $\begin{array}{r}3 \\
11 \\
1 \\
2 \\
1 \\
11 \\
9 \\
8 \\
3 \\
1 \\
1 \\
2 \\
4 \\
4 \\
21 \\
28 \\
5\end{array}$ & $\begin{array}{l}0 \\
0 \\
0 \\
0 \\
0 \\
0 \\
0 \\
0 \\
0 \\
0 \\
0 \\
0 \\
0 \\
0 \\
0 \\
0 \\
0 \\
\end{array}$ & $\begin{array}{l}1.61 \\
1.08 \\
1.22 \\
1.19 \\
1.77 \\
1.52 \\
1.39 \\
1.24 \\
1.37 \\
1.25 \\
1.14 \\
1.25 \\
1.52 \\
1.19 \\
1.16 \\
1.22 \\
2.58 \\
\end{array}$ & $\begin{array}{l}1.66 \\
1.12 \\
1.50 \\
1.33 \\
1.68 \\
1.58 \\
1.77 \\
1.40 \\
1.24 \\
1.48 \\
1.28 \\
1.18 \\
1.42 \\
1.34 \\
1.44 \\
1.47 \\
1.90 \\
\end{array}$ & $\begin{array}{c}1.44 \\
1.19 \\
1.54 \\
1.4 \\
1.88 \\
1.23 \\
1.21 \\
1.12 \\
1.39 \\
1.41 \\
1.17 \\
1.13 \\
1.65 \\
1.42 \\
1.17 \\
1.14 \\
2.06 \\
\end{array}$ \\
\hline $\begin{array}{l}\text { MF94B } \\
\text { MF95A } \\
\text { MF72Ga* } \\
\text { MF95B } \\
\text { MF72I* } \\
\text { MF46A* } \\
\text { MF73V2 } \\
\text { MF94A } \\
\text { MF73V1 } \\
\text { MF100 }\end{array}$ & $\begin{array}{l}\text { Troctolite B } \\
\text { Troctolite B } \\
\text { Troctolite B } \\
\text { Troctolite B } \\
\text { Troctolite B } \\
\text { Troctolite B } \\
\text { Troctolite B } \\
\text { Troctolite B } \\
\text { Troctolite B } \\
\text { Troctolite B } \\
\end{array}$ & $\begin{array}{l}60 \\
60 \\
59 \\
59 \\
57 \\
55 \\
55 \\
55 \\
50 \\
45 \\
\end{array}$ & $\begin{array}{l}38 \\
34 \\
31 \\
36 \\
41 \\
44 \\
39 \\
42 \\
48 \\
51\end{array}$ & $\begin{array}{r}2 \\
6 \\
10 \\
5 \\
2 \\
1 \\
6 \\
3 \\
2 \\
4\end{array}$ & $\begin{array}{l}0 \\
0 \\
0 \\
0 \\
0 \\
0 \\
0 \\
0 \\
0 \\
0\end{array}$ & $\begin{array}{l}1.11 \\
1.21 \\
1.41 \\
1.37 \\
1.15 \\
1.04\end{array}$ & $\begin{array}{l}1.09 \\
1.19 \\
1.31 \\
1.28 \\
1.12 \\
1.23\end{array}$ & \begin{tabular}{c|}
1.07 \\
1.23 \\
1.37 \\
1.36 \\
1.21 \\
1.3 \\
\\
\\
1.85 \\
1.44 \\
1.71 \\
\end{tabular} \\
\hline $\begin{array}{l}\text { MF11A1* } \\
\text { MF99 } \\
\text { MF24* } \\
\text { MF20* } \\
\text { MF2B* } \\
\text { MF2A* }\end{array}$ & $\begin{array}{l}\text { Troctolitic gabbro } \\
\text { Troctolitic gabbro } \\
\text { Olivine gabbro } \\
\text { Olivine gabbro } \\
\text { Olivine gabbro } \\
\text { Olivine gabbro }\end{array}$ & $\begin{array}{l}30 \\
30 \\
27 \\
21 \\
16 \\
15\end{array}$ & $\begin{array}{l}69 \\
66 \\
59 \\
60 \\
63 \\
68\end{array}$ & $\begin{array}{r}1 \\
4 \\
13 \\
18 \\
19 \\
16\end{array}$ & $\begin{array}{l}0 \\
0 \\
1 \\
1 \\
2 \\
1\end{array}$ & $\begin{array}{l}1.08 \\
1.06 \\
1.02 \\
1.02\end{array}$ & $\begin{array}{l}1.10 \\
1.18 \\
1.13 \\
1.04\end{array}$ & $\begin{array}{c}1.3 \\
1.17 \\
1.07 \\
1.05\end{array}$ \\
\hline
\end{tabular}

Plagio, plagioclase; Cpx, clinopyroxene; Opx, orthopyroxene; PfJ, Fabric strength of single crystallographic pole.

*Samples investigated in previous studies (Rampone et al., 2004, 2014, 2016; Borghini \& Rampone, 2007; Borghini et al., 2007; Rampone \& Borghini, 2008). (See text for further details.)

cooling of the peridotites and equilibration at lithospheric temperatures $\left(970-1100^{\circ} \mathrm{C}\right.$; Rampone et al., 2005; Rampone \& Borghini, 2008). The spinel Iherzolites display melt-rock interaction microstructures with the development of olivine embayments replacing mantle pyroxenes (i.e. pyroxene dissolution and olivine crystallization). These microstructures, associated with an increase in olivine modal compositions, have been extensively described in the Alpine-Apennine ophiolites (Piccardo et al., 2004; Rampone et al., 2005, 2008; Piccardo \& Vissers, 2007; Rampone \& Borghini, 2008; Basch et al., 2018) and in the Othris Massif (Dijkstra et al., 2003), and have been interpreted as the result of a pyroxene-dissolving, olivine-crystallizing reactive melt percolation at spinel facies.

\section{Plagioclase Iherzolites}

These have been previously described as the replacive product of melt impregnation of the spinel Iherzolites (Borghini et al., 2007). They show similar textures and microstructures to the spinel-facies protolith, but are characterized by an enrichment in undeformed interstitial plagioclase and orthopyroxene (Table 1), developing embayments on kinked olivine and exsolved clinopyroxene. These melt-rock reaction microstructures are indicative of an orthopyroxene-saturated composition of the impregnated melt, as previously described for the Alpine-Apennine ophiolitic peridotites (Rampone et al., 1997, 2005, 2008, 2016, 2018; Müntener \& Piccardo, 2003; Piccardo et al., 2004; Borghini \& Rampone, 2007; Borghini et al., 2007; 

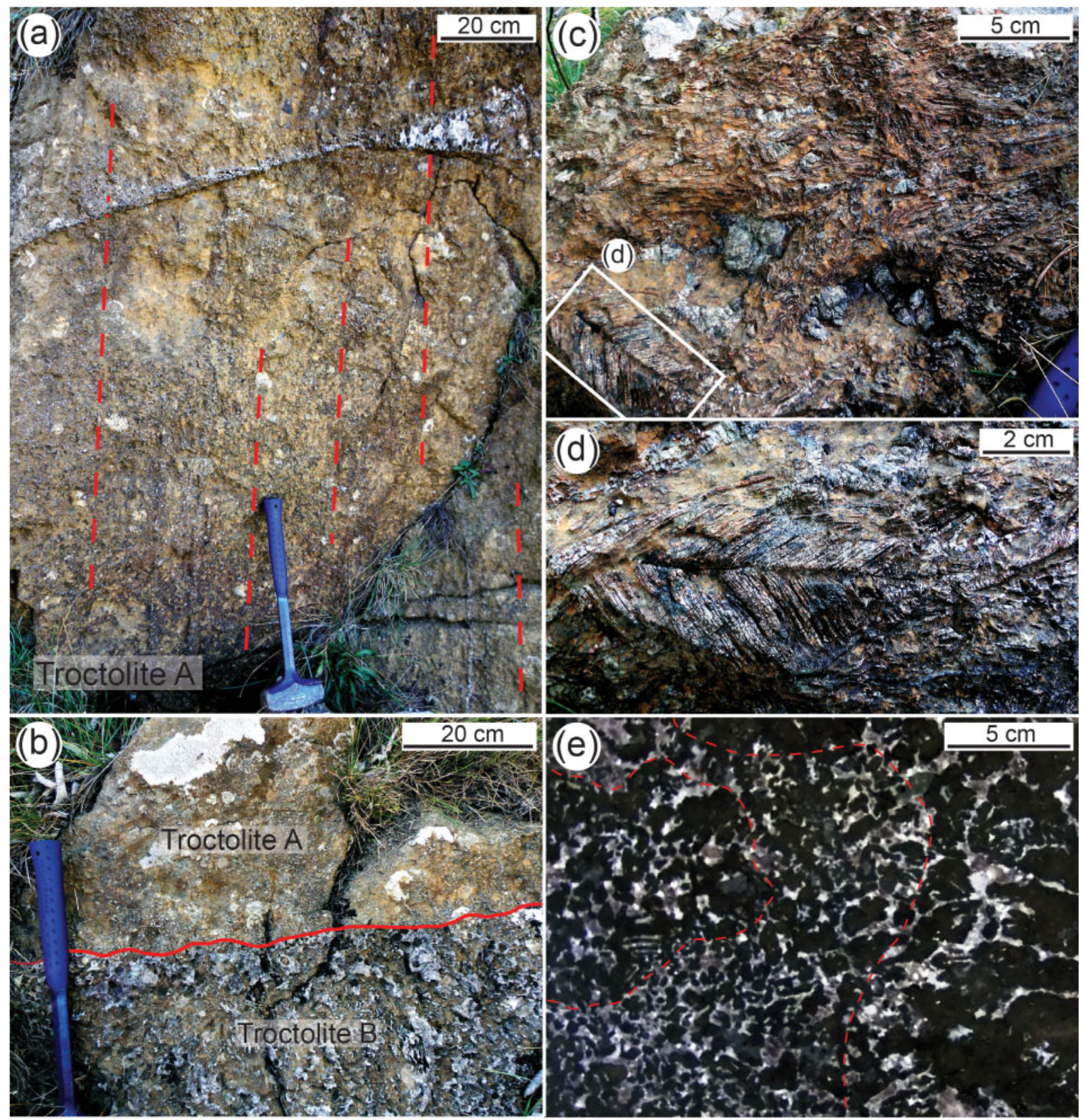

Fig. 3. Troctolite B field structures. (a) Troctolite B crosscutting the layering of plagioclase enrichment in Troctolite A (red dashed lines). (b) Irregular contact between Troctolite A and crosscutting Troctolite B. (c) Textural complexity within Troctolite B. The white rectangle indicates the location of (d). (d) Dendritic 'fishbone' olivine crystal. (e) Textural variability of olivine crystals at a centimetre-scale within Troctolite B. The dashed red line separates granular olivine domains from hopper and dendritic olivine domains.

Rampone \& Borghini, 2008; Basch et al., 2018) and in the Othris Massif (Dijkstra et al., 2003).

\section{Troctolite A}

This has a hypidiomorphic texture and variable grain size, from centimetre-size anhedral to millimetre-size euhedral olivine crystals. Olivine occurs as either (1) fine-grained undeformed euhedral crystals embedded in interstitial to poikilitic plagioclase and clinopyroxene (Fig. 5a and b) or (2) coarse (up to centimetre-size) deformed corroded grains, displaying kink bands (Fig. $5 c$ and d). These two types of olivine are commonly found together, and in places fine-grained euhedral crystals of olivine embedded in poikilitic plagioclase or clinopyroxene show the same crystallographic orientation as a neighbouring coarse corroded grain of olivine (Fig. 5c).

Within Troctolite $A$, the textural variability includes small dunitic domains (olivine $>90$ vol. \%; Fig. $6 a-c$ ), in which interstitial plagioclase surrounds millimetre-size to centimetre-size zones free of interstitial minerals, and 


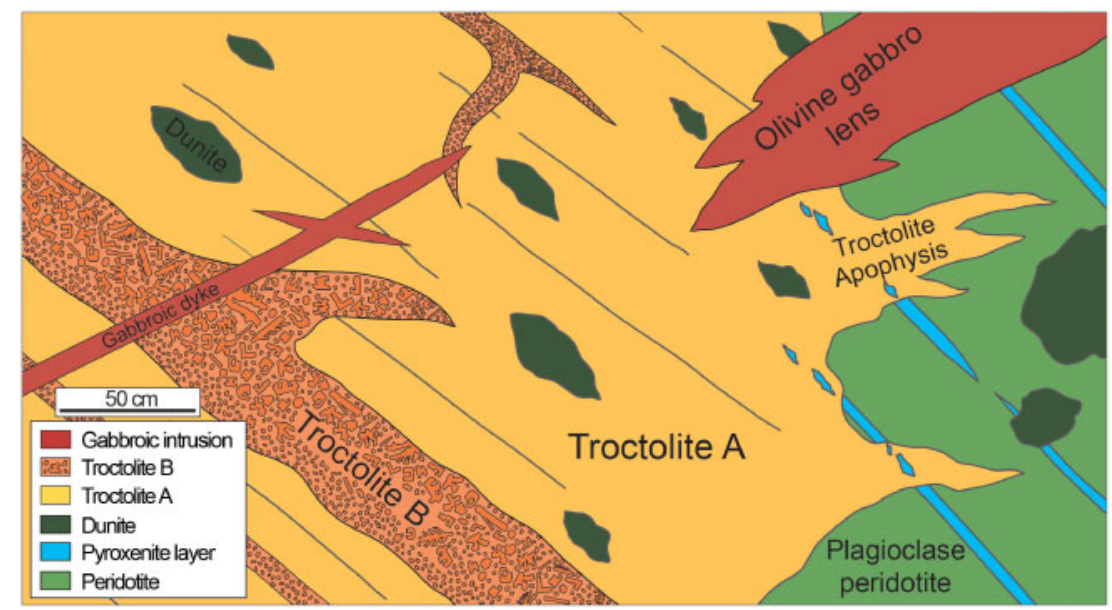

Fig. 4. Representative sketch of the crosscutting relationships observed in the field between the impregnated peridotites, the composite troctolitic body, and the gabbroic intrusions.
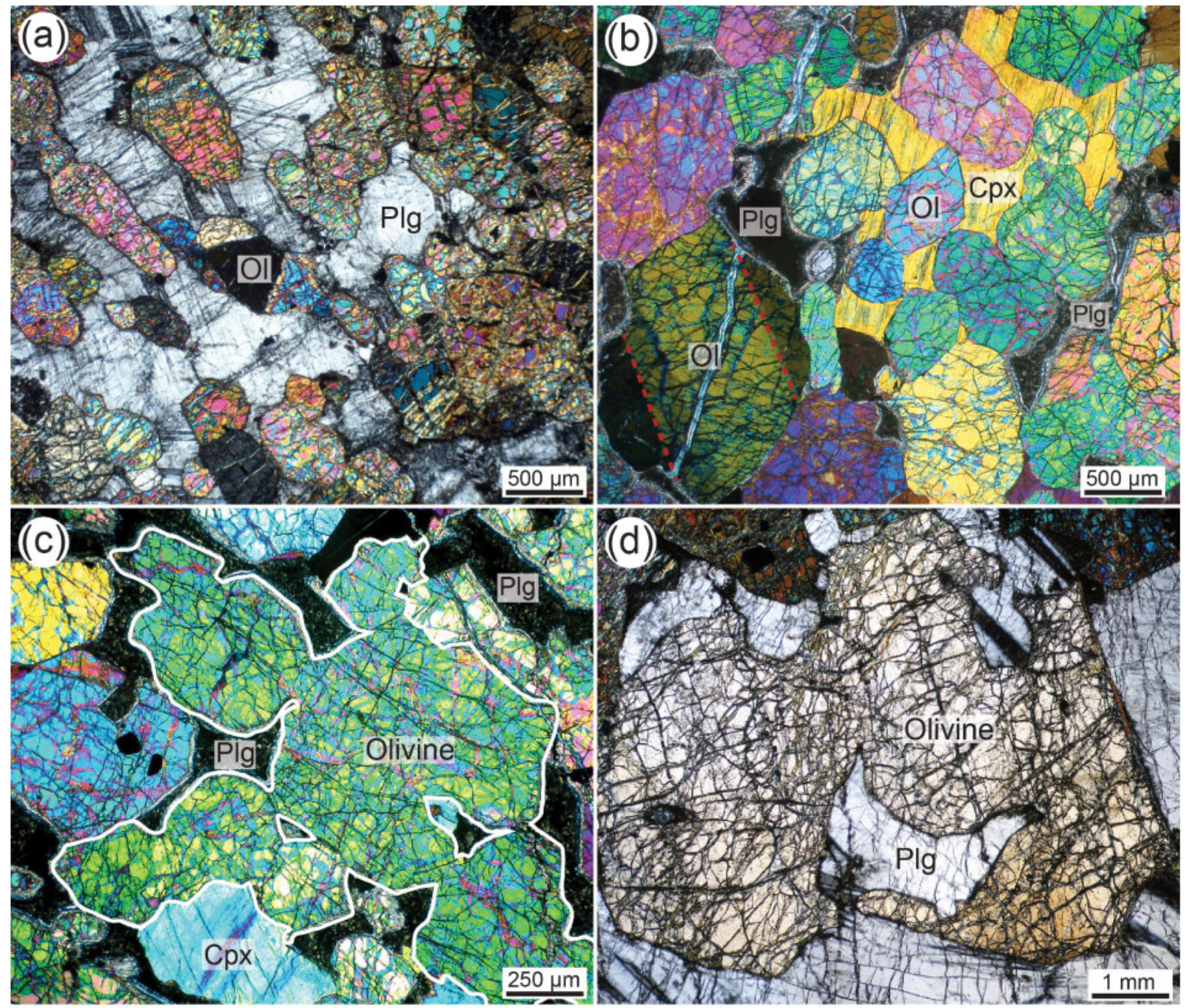

Fig. 5. Textural variability in Troctolite A. (a) Granular olivine matrix embedded in undeformed poikilitic plagioclase. (b) Granular olivine matrix embedded in poikilitic clinopyroxene. The largest olivine crystal shows the occurrence of kink bands, highlighted by the red dashed lines. Interstitial plagioclase has been replaced by low-grade alteration phases. (c) Corroded olivine grain prior to disruption into several smaller crystals. Interstitial plagioclase has been replaced by low-grade alteration phases. (d) Highly corroded centimetre-size olivine, embedded in poikilitic plagioclase. 

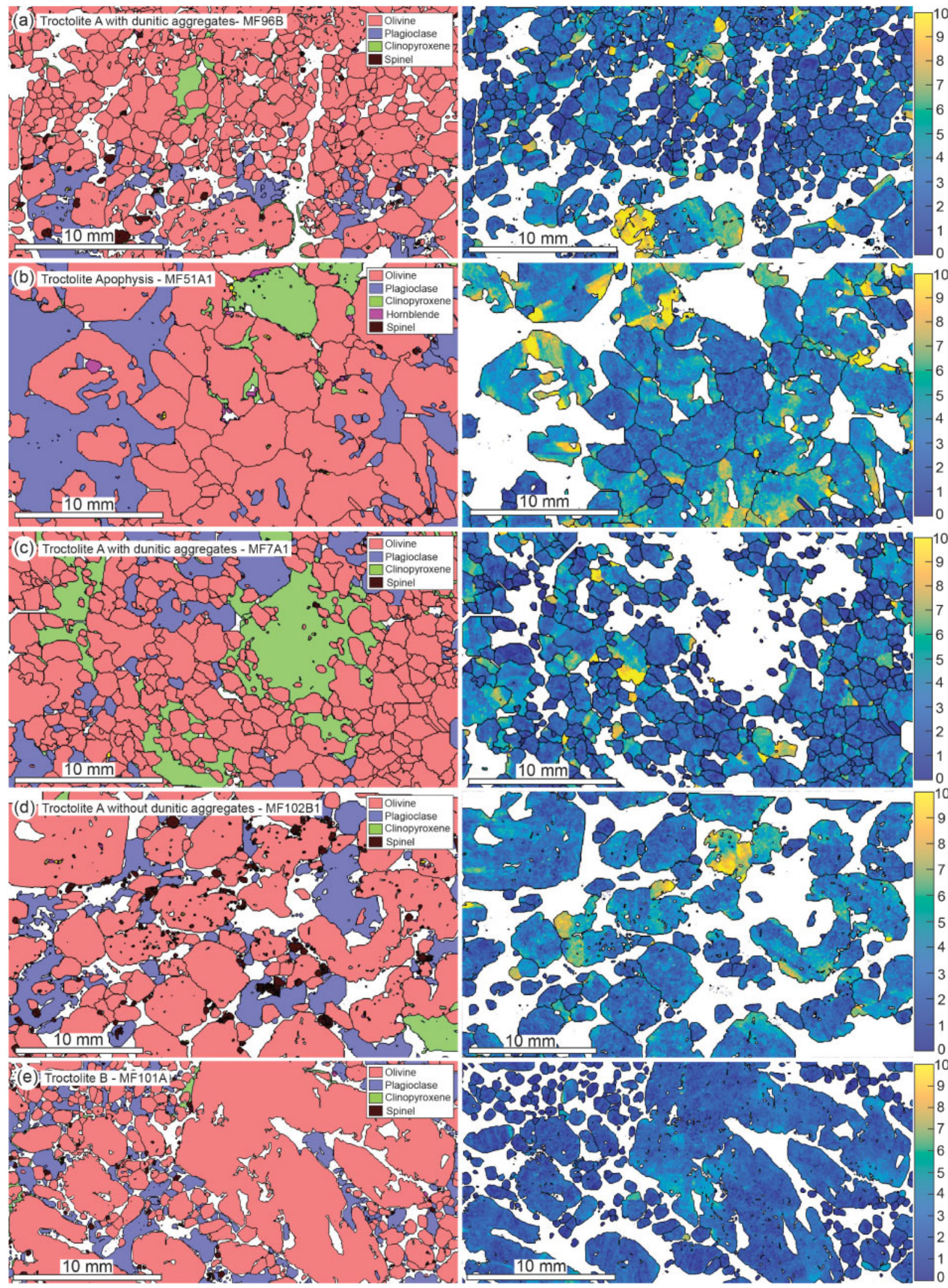

Fig. 6. EBSD phase (left column) and olivine misorientation (right column) maps showing the textural variability of the olivine matrix within the troctolitic body. (a) Troctolite A with dunitic aggregates MF96B; (b) troctolite apophysis MF51A1; (c) Troctolite A with dunitic aggregates MF7A1; (d) Troctolite A without dunitic aggregates MF102B1; (e) Troctolite B MF101A. White areas in the phase maps are non-indexed pixels, mostly corresponding to altered plagioclase. 
plagioclase-rich domains (Fig. 6d) in which single olivines are entirely embedded in poikilitic plagioclase \pm clinopyroxene. Clinopyroxene, orthopyroxene, and amphibole are found as thin 'vermicular' crystals at the contact between olivine and poikilitic minerals and have been previously interpreted as post-cumulus crystallization of trapped melts (progressively evolving during late-stage closed-system crystallization; Borghini \& Rampone, 2007; Borghini et al., 2007). Spinels are found in the matrix, both associated with olivine as millimetre-size corroded grains (Fig. 6a, d) and with poikilitic plagioclase and clinopyroxene, as subhedral to euhedral smaller grains $(\sim 100-200 \mu \mathrm{m}$, Fig. 6d). Troctolite apophyses (part of Troctolite A) are very rich in coarse, deformed, corroded grains of olivine (Fig. 6b), and undeformed fine-grained olivine is rare.

\section{Troctolite B}

These pseudo-tabular bodies crosscut the host Troctolite A structures. They are characterized by lower olivine modal contents (from 45 to 60 vol. \%; Table 1) than the host Troctolite A (from 55 to 97 vol. \% olivine; Table 1). Moreover, Troctolite $B$ shows extreme olivine textural variation, from millimetre-size euhedral crystals (Fig. 7a) to centimetre-size hopper (Fig. 7b), to decimetre-size dendritic and skeletal olivine (Figs $3 b-e$ and $7 \mathrm{c}, \mathrm{d}$ ), all showing absent to weak deformation (Fig. 6e). In places, this textural variability leads to the formation of layering (Fig. 4), but all olivine morphologies can also be found together at the centimetre scale (Fig. 6e).

\section{Gabbroic intrusions}

These include gabbroic lenses, dykes and dykelets, mostly of olivine gabbro and minor troctolite, displaying hypidiomorphic textures and a fine- to coarsegrained olivine size. Subhedral plagioclase is the main rock-forming mineral (from 59 to $69 \mathrm{vol}$ \% modal content of plagioclase; Table 1). Clinopyroxene is mostly found as large anhedral crystals including preexisting euhedral plagioclase \pm olivine. Olivines (from 15 to 30 vol. \% modal olivine; Table 1) are found both as euhedral grains included in plagioclase \pm clinopyroxene and as anhedral interstitial crystals in plagioclase-clinopyroxene-olivine aggregates, indicative of eutectic crystallization of the melt. These textural features in the gabbroic intrusions are indicative of an olivine-plagioclase-clinopyroxene crystallization sequence.

\section{OLIVINE CRYSTALLOGRAPHIC PREFERRED ORIENTATIONS}

In all studied samples of spinel Iherzolite, plagioclase Iherzolite and troctolite, a clear and representative olivine CPO could be quantified; however, because of the large grain size of the plagioclase and pyroxenes (Fig. 8; Bunge, 1982; Ben Ismail \& Mainprice, 1998), no reliable
CPO of the interstitial minerals could be obtained at the thin-section scale. In the gabbroic intrusions, finegrained euhedral plagioclase crystals also allow a representative quantification of the plagioclase CPO (Fig. 9).

\section{Spinel Iherzolites}

Olivines in spinel Iherzolites (ETR2, ETR4A, ETR4B in Table 1) are characterized by an axial-[100] CPO, with the [100] axis showing the strongest preferred orientation in the foliation plane, parallel to the lineation, [010] axis maximum oriented normal to the foliation plane, and [001] maximum within the foliation plane, normal to the lineation (Fig. 8). The J-index, representative of the fabric strength (e.g. Bunge, 1982; Ben Ismail \& Mainprice, 1998; Mainprice et al., 2014), ranges from 3.64 to 5.59 in spinel peridotites. Most natural peridotites show $\mathrm{J}$-index values of olivine $\mathrm{CPO}$ between two and 20 (Tommasi et al., 2000; Soustelle et al., 2009).

\section{Plagioclase Iherzolites}

Olivines in plagioclase lherzolites (P1A, P1B in Table 1) are characterized by a strong axial-[010] CPO ( $\mathrm{J}$-index = 5.5-7), with the strongest axis orientation being [010] normal to the foliation, and a girdle orientation of [100] and [001] within the foliation plane, showing a maximum parallel and normal to the lineation, respectively (Fig. 8).

\section{Troctolite $A$ with dunitic aggregates}

In Troctolite A with dunitic aggregates (Fig. 6a-C; MF7A1, MF7A2, MF7C1, MF96A, MF96B in Table 1) and in the dunite pod associated with Troctolite A (MF104A in Table 1, Fig. 2c), all samples are characterized by a relatively weak (J-index $=2.04-3.83$ ) but clear axial[100] olivine CPO, with strongly oriented [100] axes within the foliation plane, [010] axes normal to the foliation, and a scatter of the [001] olivine axis orientations (Fig. 8). This olivine CPO is similar to that observed in the spinel Iherzolites (Fig. 8).

\section{Troctolite apophyses}

These show a range of weak olivine CPOs from axial[100] to axial-[010] ( $\mathrm{J}$-index $=1 \cdot 86-2 \cdot 1)$, similar to the CPO observed in spinel lherzolites and plagioclase lherzolites, respectively.

\section{Troctolite $A$ without dunitic aggregates}

Troctolite A without dunitic aggregates (Fig. 6d; MF21, MF15, MF97, MF102B1 in Table 1) shows a very weak to random orientation of the [100] and [010] axes, and increased concentrations of the [001] olivine axis (Jindex $=2 \cdot 17-3 \cdot 06$ ).

\section{Gabbroic intrusions}

These (MF20Il, MF24, MF11A1, MF99 in Table 1) show very weak olivine CPO (J-index $=1.21-1.83)$ 

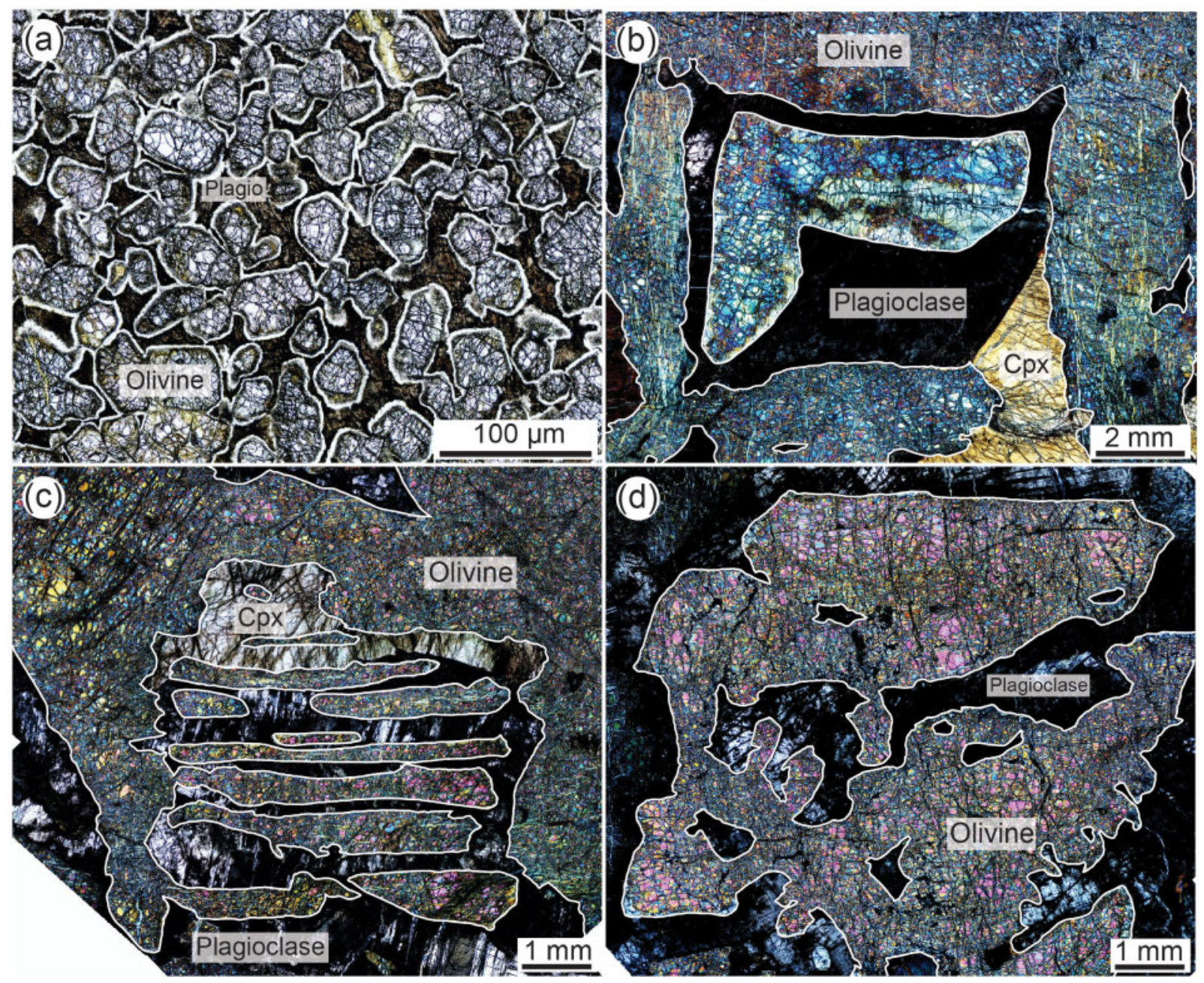

Fig. 7. Textural variability observed in the Troctolite B pseudo-tabular bodies. Plagioclase is partly to completely replaced by lowgrade alteration phases. (a) Fine-grained granular undeformed olivines surrounded by a rim of chlorite; (b) partially corroded coarse hopper crystal of olivine, associated with poikilitic plagioclase and interstitial clinopyroxene; (c) coarse skeletal olivine showing the inner 'branches' of olivine, associated with interstitial plagioclase and clinopyroxene; (d) single coarse skeletal olivine associated with interstitial plagioclase.

characterized by [010] and [001] showing clear maxima normal and within the foliation plane, respectively (Fig. 9). Plagioclase shows a weak (J-index $=1.79-4.60)$ (010)[100] CPO characterized by a strong orientation of the [010] axis normal to the foliation plane (Fig. 9).

\section{Troctolite B}

Olivines in the granular part of Troctolite B (MF46A, MF94B in Table 1) are characterized by a strong orientation of the [010] and [001] axes normal and within the foliation plane, parallel to the lineation, respectively (Fig. 9). This (010)[001] olivine CPO is similar to that observed in the gabbroic intrusions (Benn \& Allard, 1989; Jousselin et al., 2012). The coarse poikilitic minerals in Troctolite B samples do not allow a reliable characterization of the plagioclase CPO at the thin-section scale (Fig. 9).

\section{MAJOR ELEMENT MINERAL COMPOSITIONS}

Representative major element compositions of olivine, clinopyroxene, plagioclase, orthopyroxene and spinel analyzed in spinel lherzolites, plagioclase Iherzolites, Troctolites A, dunite, Troctolites $B$ and gabbroic intrusions are reported in Tables 2-6 and the complete dataset is given in Supplementary Data Tables S1-S5. Overall our data show consistency with mineral compositions reported in previous studies of the Erro-Tobbio peridotites and associated gabbroic rocks (troctolitic body and gabbroic lenses and dykes) (Rampone et al., 1993, 1998, 2004, 2005, 2016; Borghini \& Rampone, 2007; Borghini et al., 2007).

\section{Olivine}

Olivines in spinel Iherzolites and plagioclase Iherzolites have rather homogeneous high forsterite contents (Fo 

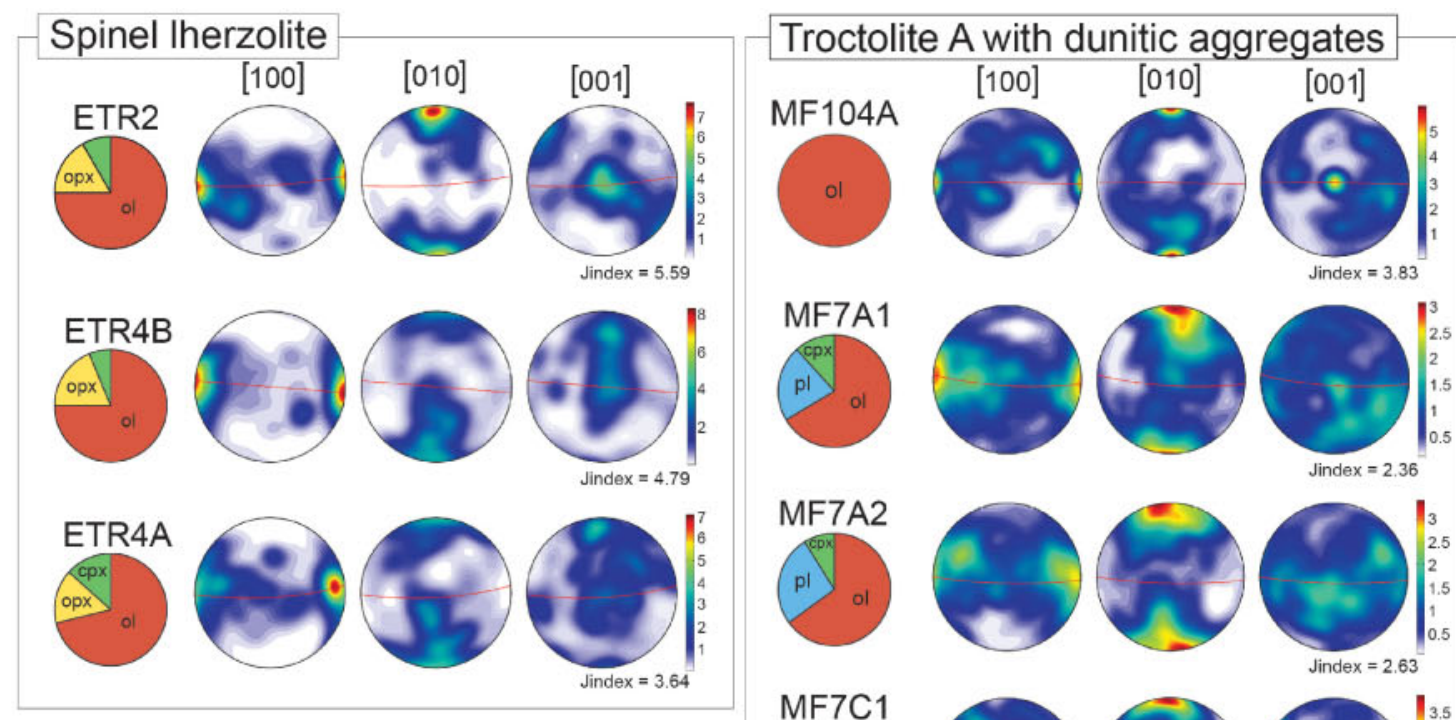

Plagioclase Iherzolite
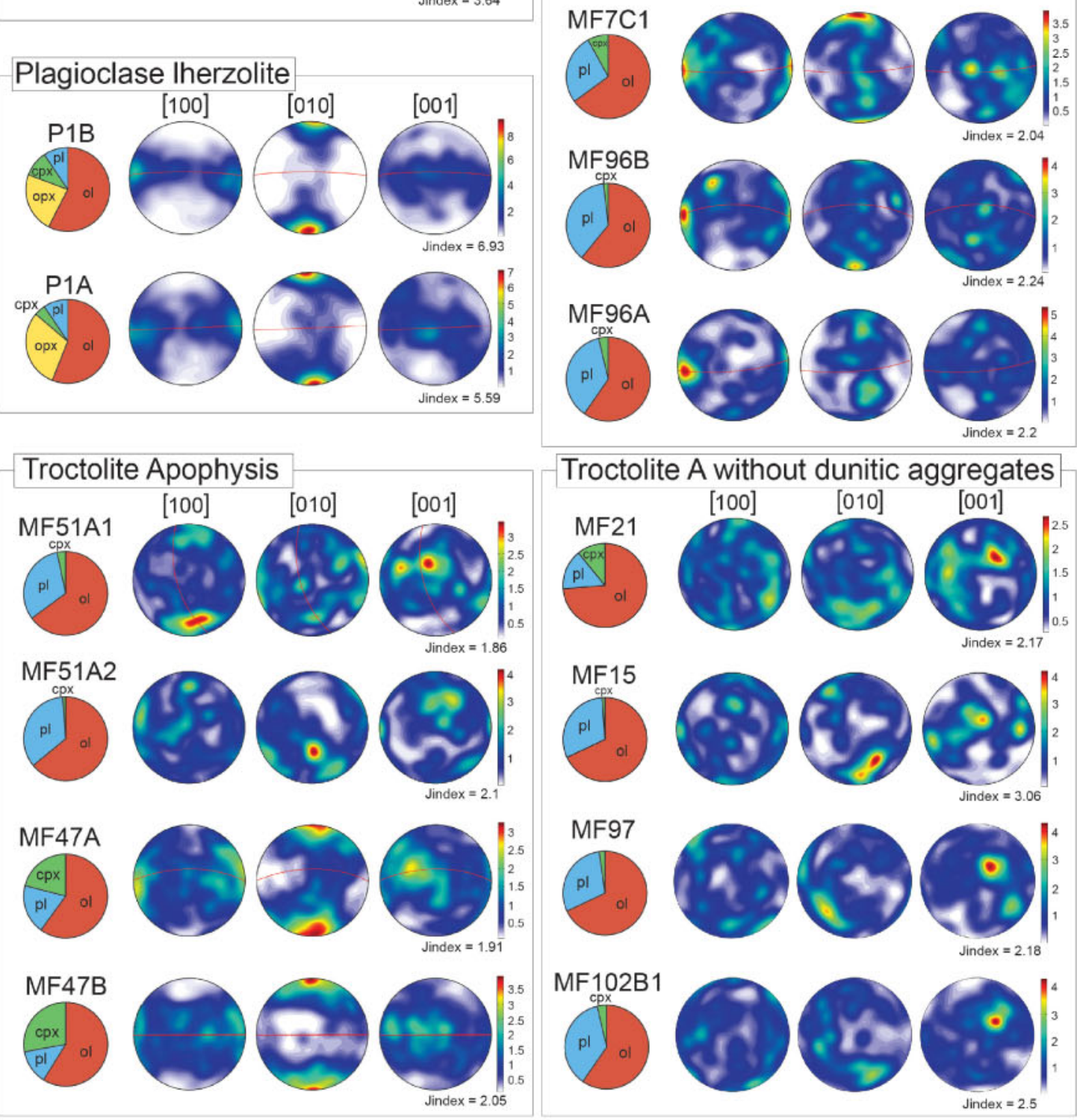

Fig. 8. Modal compositions and olivine crystallographic preferred orientation of spinel Iherzolite, plagioclase Iherzolite, troctolite apophysis and Troctolite A, with and without olivine aggregates. One-point-per-grain, equal-area, lower hemisphere stereographic projections. The colour bar is scaled to the maximum concentration of the three crystallographic axes. The foliation is indicated by the red line in oriented samples. J-index refers to the fabric strength. 

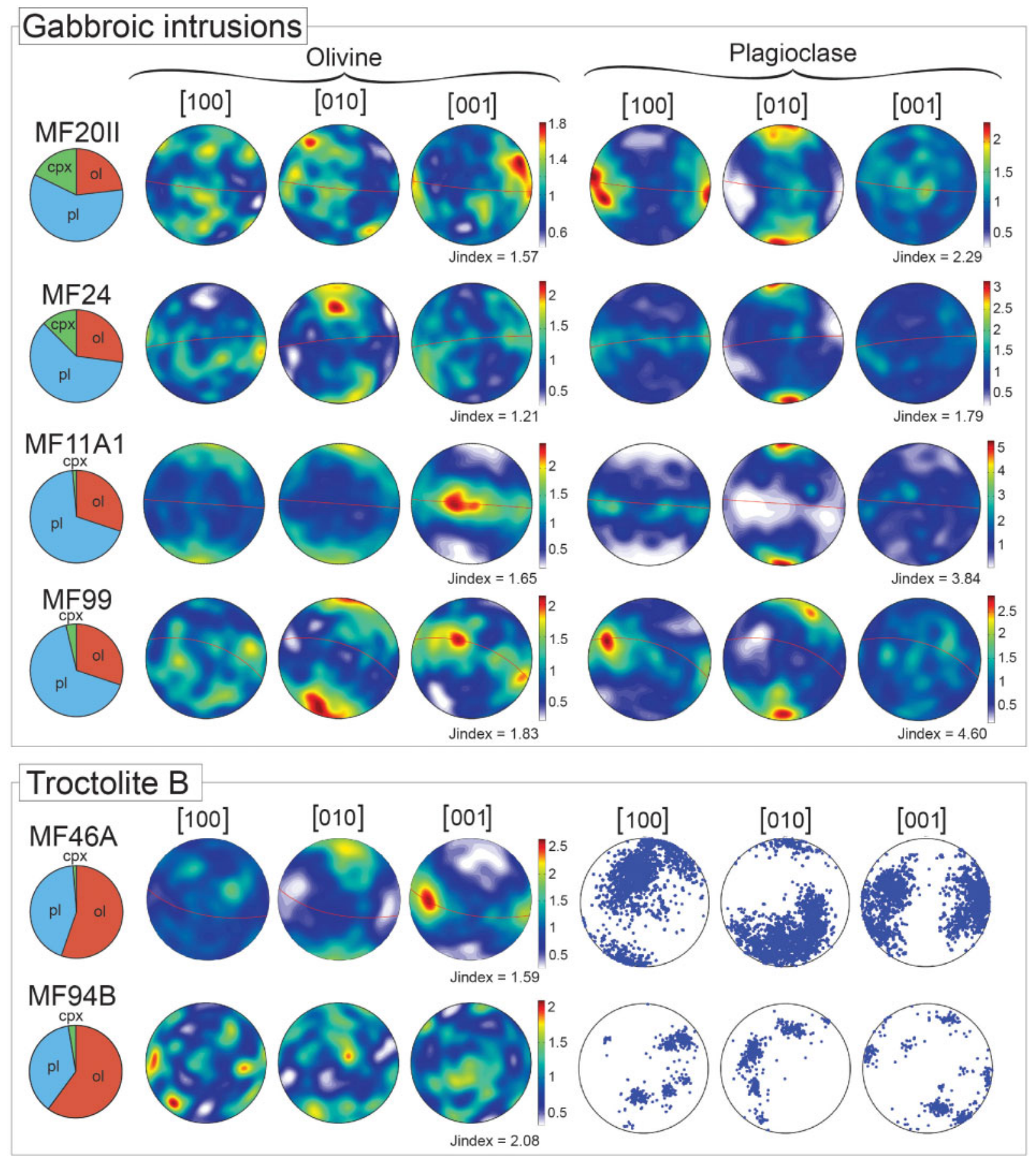

Fig. 9. Modal composition, olivine and plagioclase crystallographic preferred orientation of gabbroic intrusion and Troctolite $B$ samples. One-point-per-grain equal-area, lower hemisphere stereographic projections. The colour bar is scaled to the maximum concentration of the three crystallographic axes. The foliation is indicated by the red line in oriented samples. J-index refers to the fabric strength.

$=89.5-90.5 \mathrm{~mol} \%$ and $\mathrm{Fo}=89.6-90.3 \mathrm{~mol} \%$, respectively; Fig. 10a) (Table 2). Olivines in Troctolites A and B have lower and more variable forsterite contents (Fo $=$ 87.3-89.2 mol \%). Within the troctolitic body, the main variations are observed between samples rather than within a single sample (Fig. 10a). No correlation is observed between the different olivine morphologies described in Troctolite A or B and forsterite contents. Olivines within the dunite pod associated with Troctolite A show contents of forsterite $=88.2-89.1 \mathrm{~mol}$ $\%$ similar to olivines in Troctolite A (Fig. 10a). The wehrlite apophysis MF47A (Table 1) has the lowest forsterite content analyzed in Troctolite A ( $F o=87.3-87.7 \mathrm{~mol} \%$ ). Gabbroic intrusions show a wide range of variation of 
Table 2: Representative major element olivine composition

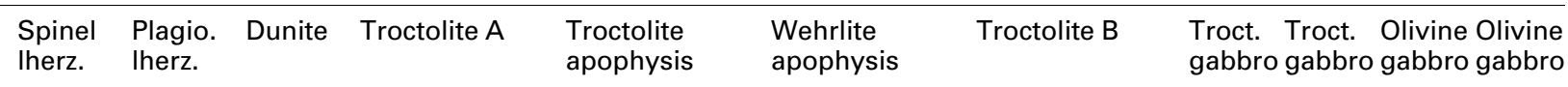

$w t \%$ Corr.def. Corr.def. Corr.def. Corr.def. Granu. Corr.def. Granu. Corr.def. Granu. Corr.def.. Granu. Granu. Granu. Granu. Granu.

\begin{tabular}{|c|c|c|c|c|c|c|c|c|c|c|c|c|c|c|c|}
\hline $\mathrm{SiO}_{2}$ & $41 \cdot 18$ & $41 \cdot 10$ & $40 \cdot 80$ & 40.52 & 40.42 & 40.86 & 40.57 & 40.89 & 40.66 & $40 \cdot 70$ & 40.49 & 40.63 & $40 \cdot 43$ & 39.74 & 39.70 \\
\hline $\mathrm{TiO}_{2}$ & 0.04 & 0.02 & 0.02 & 0.03 & b.d.I. & b.d.I. & 0.03 & 0.04 & 0.04 & 0.02 & b.d.I. & 0.01 & b.d.l. & b.d.l. & 0.03 \\
\hline $\mathrm{Al}_{2} \mathrm{O}_{3}$ & 0.01 & b.d.l. & 0.01 & b.d.l. & 0.02 & b.d.l. & 0.03 & b.d.l. & b.d.l. & b.d.l. & 0.04 & b.d.l. & 0.02 & b.d.I. & b.d.I. \\
\hline $\mathrm{Cr}_{2} \mathrm{O}_{3}$ & b.d.l. & b.d.l. & 0.02 & b.d.I. & b.d.l. & b.d.l. & b.d.l. & 0.01 & b.d.l. & 0.05 & b.d.l. & b.d.I. & b.d.l. & b.d.I. & b.d.l. \\
\hline $\mathrm{FeO}$ & 9.64 & 10.05 & 11.29 & 11.65 & 11.75 & 11.31 & 11.29 & 11.81 & 11.96 & 11.61 & 11.52 & 11.11 & 13.38 & $16 \cdot 11$ & 17.57 \\
\hline $\mathrm{MgO}$ & 49.47 & 48.99 & 47.65 & 48.05 & 48.02 & 48.01 & 48.21 & $47 \cdot 33$ & $47 \cdot 33$ & 47.90 & 48.05 & $48 \cdot 22$ & 46.49 & 44.35 & $43 \cdot 1$ \\
\hline $\mathrm{MnO}$ & 0.11 & 0.16 & 0.21 & 0.18 & 0.15 & 0.23 & 0.15 & 0.20 & 0.22 & 0.18 & 0.17 & 0.17 & 0.21 & 0.27 & 0.33 \\
\hline $\mathrm{NiO}$ & 0.37 & 0.43 & 0.28 & 0.30 & 0.28 & 0.33 & 0.29 & 0.27 & 0.31 & 0.31 & 0.32 & 0.33 & 0.26 & 0.21 & 0.1 \\
\hline $\mathrm{CaO}$ & 0.03 & 0.06 & 0.09 & 0.06 & 0.04 & 0.07 & 0.05 & 0.05 & 0.04 & 0.08 & 0.02 & 0.04 & 0.01 & b.d.I. & 0.0 \\
\hline otal & $100 \cdot 85$ & $100 \cdot 83$ & $100 \cdot 37$ & $100 \cdot 81$ & 100.69 & $100 \cdot 84$ & 100.63 & $100 \cdot 60$ & 100.58 & $100 \cdot 86$ & 100.63 & $100 \cdot 54$ & $100 \cdot 80$ & 100.68 & $100 \cdot 9$ \\
\hline g\# & 90.14 & 89.68 & $88 \cdot 27$ & 88.03 & 87.93 & 88.33 & 88.39 & 87.72 & 87.58 & 88.03 & $88 \cdot 14$ & 88.55 & $86 \cdot 10$ & 83.07 & 81.4 \\
\hline
\end{tabular}

$\mathrm{Mg} \#=\mathrm{Mg} /(\mathrm{Mg}+\mathrm{Fe})$; Spinel Iherz., spinel Iherzolite; Plagio. Iherz., plagioclase Iherzolite; Troct. gabbro, troctolitic gabbro; Corr.def., corroded-deformed; Granu., granular; b.d.I., below detection limit.

forsterite contents in olivine, from primitive compositions in the troctolitic intrusions (up to Fo $=89.2 \mathrm{~mol} \%$ ) to more evolved compositions in olivine gabbros $(\mathrm{Fo}=$ $81.3 \mathrm{~mol} \%$ ) (Table 1; Fig. 10b).

\section{Clinopyroxene}

Clinopyroxene cores in spinel Iherzolites have high Mgnumbers ( $\mathrm{Mg \#}=90.0-91.6 \mathrm{~mol} \%$ ), high $\mathrm{Cr}_{2} \mathrm{O}_{3}=0.82-$ 1.33 wt $\%$ and $\mathrm{Al}_{2} \mathrm{O}_{3}=5.2-7.4 \mathrm{wt} \%$, and low $\mathrm{TiO}_{2}=$ 0.30-0.58 wt \% (Table 3; Fig. 11a and b) contents. Impregnated plagioclase Iherzolites show similar Mgnumbers $(\mathrm{Mg} \#=89.6-91.1 \mathrm{~mol} \%)$ and $\mathrm{TiO}_{2}=0.4-$ 0.53 wt $\%$ contents, higher $\mathrm{Cr}_{2} \mathrm{O}_{3}=1.02-1.40$ wt $\%$, and lower $\mathrm{Al}_{2} \mathrm{O}_{3}=2.83-5.27 \mathrm{wt} \%$ concentrations. Gabbroic intrusions exhibit clinopyroxene compositions consistent with olivine gabbros and troctolites from the SouthWest Indian Ridge (Dick et al., 2002), with a positive correlation between $\mathrm{Mg}$-number $(\mathrm{Mg} \#=83.5-90.8 \mathrm{~mol} \%)$, $\mathrm{Cr}\left(\mathrm{Cr}_{2} \mathrm{O}_{3}=0.18-1.15 \mathrm{wt} \%\right)$, and $\mathrm{Al}\left(\mathrm{Al}_{2} \mathrm{O}_{3}=2.4-3.7 \mathrm{wt}\right.$ $\%)$, and a negative correlation with $\mathrm{Ti}\left(\mathrm{TiO}_{2}=0.42\right.$ $1.41 \mathrm{wt} \%$ ) (Fig. 11a and b). Clinopyroxenes in Troctolite $\mathrm{A}$ (and associated dunite) and Troctolite $\mathrm{B}$ show high $\mathrm{Cr}$ $\left(\mathrm{Cr}_{2} \mathrm{O}_{3}=1.17-1.67 \mathrm{wt} \%\right)$ and low $\mathrm{Al}\left(\mathrm{Al}_{2} \mathrm{O}_{3}=3.1-\right.$ $5.0 \mathrm{wt} \%)$ and $\mathrm{Ti}$ contents $\left(\mathrm{TiO}_{2}=0.12-0.92 \mathrm{wt} \%\right)$ (Fig. 11a and b).

Figure 11c and d shows the correlation between the clinopyroxene composition and its microstructural site. As previously documented by Borghini \& Rampone (2007), clinopyroxenes in Troctolite A show progressively decreasing $\mathrm{Cr}_{2} \mathrm{O}_{3}\left(\mathrm{Cr}_{2} \mathrm{O}_{3}=0.78-1.67 \mathrm{wt} \%\right)$ and increasing $\mathrm{TiO}_{2}\left(\mathrm{TiO}_{2}=0.12-1.24 \mathrm{wt} \%\right)$ contents from core to rim to interstitial to vermicular microstructural sites, at constant $\mathrm{Mg}$-number ( $\mathrm{Mg} \#=87.7-91.0 \mathrm{~mol} \%$ ).

The $\mathrm{Cr}_{2} \mathrm{O}_{3}, \mathrm{Al}_{2} \mathrm{O}_{3}$ and $\mathrm{TiO}_{2}$ compositional variability in clinopyroxene is well observed in major element core-rim profiles within single clinopyroxene grains (Fig. 12a-d). A progressive decrease in $\mathrm{Cr}_{2} \mathrm{O}_{3}$ (from 1.5 to $1.0 \mathrm{wt} \%$ ) and $\mathrm{Al}_{2} \mathrm{O}_{3}$ (from 4 to $3 \mathrm{wt} \%$ ), coupled with an increase in $\mathrm{TiO}_{2}$ (from 0.4 to $1 \mathrm{wt} \%$ ), is observed in the profiles, from the inner core towards the contact
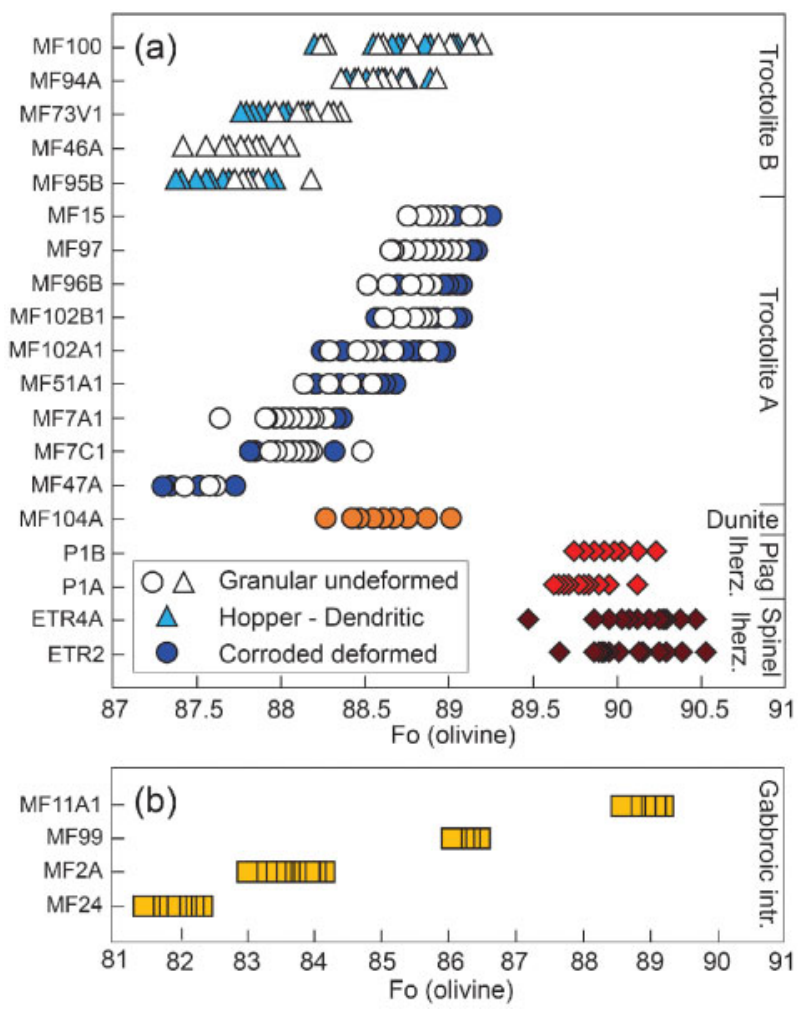

Fig. 10. Range of forsterite contents in olivines in (a) spinel Iherzolite, plagioclase Iherzolite, dunite, Troctolite $A$ and Troctolite $B$ and (b) gabbroic intrusions. Olivine morphology is divided into granular-undeformed and corroded-deformed within Troctolite A, and granular-undeformed and hopperdendritic within Troctolite B.

between clinopyroxene and olivine (Rampone et al., 2005). As documented by Borghini et al. (2007), the strong heterogeneity of $\mathrm{Cr}_{2} \mathrm{O}_{3}, \mathrm{TiO}_{2}$ and $\mathrm{Al}_{2} \mathrm{O}_{3}$ in the clinopyroxenes of Troctolite $A$ (Fig. $11 \mathrm{c}$ and $\mathrm{d}$ ) is thus related to within-sample variations, clearly correlated with microstructural site. Geochemical variations in the profiles are observed from $\sim 200 \mu \mathrm{m}$ to the contact with the olivine (Fig. 12a-d). 
Table 3: Representative major element clinopyroxene composition

\begin{tabular}{|c|c|c|c|c|c|c|c|c|c|c|c|c|c|c|c|c|}
\hline \multirow[b]{2}{*}{$w t \%$} & \multirow{2}{*}{$\begin{array}{l}\text { Spinel } \\
\text { Iherz. } \\
\text { Core }\end{array}$} & \multicolumn{2}{|l|}{$\begin{array}{l}\text { Plagio. } \\
\text { Iherz. }\end{array}$} & \multirow{2}{*}{$\begin{array}{l}\text { Dunite } \\
\text { Core }\end{array}$} & \multicolumn{2}{|c|}{$\begin{array}{l}\text { Troctolite } \\
\text { A }\end{array}$} & \multicolumn{2}{|c|}{$\begin{array}{l}\text { Troct. } \\
\text { apophysis }\end{array}$} & \multirow{2}{*}{$\begin{array}{l}\text { Wehrlite } \\
\text { apophysis } \\
\text { Core }\end{array}$} & \multicolumn{2}{|c|}{$\begin{array}{l}\text { Troctolite } \\
\text { B }\end{array}$} & \multirow{2}{*}{$\begin{array}{l}\text { Troct. } \\
\text { gabbro } \\
\text { Core }\end{array}$} & \multicolumn{2}{|c|}{$\begin{array}{l}\text { Troct. } \\
\text { gabbro }\end{array}$} & \multirow{2}{*}{$\begin{array}{l}\text { Olivine } \\
\text { gabbro } \\
\text { Core }\end{array}$} & \multirow{2}{*}{$\begin{array}{l}\text { Olivine } \\
\text { gabbro } \\
\text { Core }\end{array}$} \\
\hline & & Core & Rim & & Core & Rim & Core & Rim & & Core & Rim & & Core & Rim & & \\
\hline $\mathrm{SiO}_{2}$ & 51.24 & 51.70 & 50.98 & 52.05 & $52 \cdot 31$ & 51.70 & 52.74 & 51.05 & 52.62 & & & & 51.76 & 51.72 & 51.92 & 52.70 \\
\hline & & & & & & 0.92 & 0.58 & 1.0 & & & 1.02 & & 0.73 & 0.75 & & 0.73 \\
\hline & 6.5 & 4.48 & 4.8 & 2. & & 3.34 & 3.0 & 2.9 & & 3. & 3.2 & 3. & 3 & 3 & & 2.51 \\
\hline $\mathrm{r}_{2} \mathrm{O}_{3}$ & 1.10 & 1.46 & 1.34 & 1.32 & 1.43 & $1 \cdot 16$ & 1.08 & 1.00 & & 1. & & & 01 & 1. & & 0.28 \\
\hline & & 3.01 & 3.20 & 3.08 & & 3.22 & 3.43 & 3.3 & & & & & & & & $5 \cdot 15$ \\
\hline & & & 16 & & & 16. & & 17. & & & & & & & & $17 \cdot 25$ \\
\hline & & & & & & & & & & & & & & & & 0.16 \\
\hline & & & & & d.I. & 0.04 & & 0.0 & & & 0.0 & & 0.07 & 0.06 & b.d.l. & 0.03 \\
\hline $\mathrm{CaO}$ & $22 \cdot 25$ & $22 \cdot 86$ & $22 \cdot 29$ & 21.74 & 20.90 & 22.03 & 21.47 & $21 \cdot 26$ & $22 \cdot 17$ & 21.60 & 22.49 & 21.85 & 20.61 & 21.61 & 22.65 & $20 \cdot 30$ \\
\hline $\mathrm{Na}_{2} \mathrm{O}$ & 0.71 & 0.38 & & & & 0.56 & 0.05 & 0.58 & & & & & 0.46 & 0.60 & & 0.45 \\
\hline Total & $100 \cdot 45$ & $100 \cdot 20$ & & & & & & & & & & & & & & \\
\hline Mg\# & & & & & & 90.03 & & & & 88.84 & & $90 \cdot 10$ & $87 \cdot 21$ & 88.48 & 86.70 & 85.65 \\
\hline
\end{tabular}

$\mathrm{Mg} \#=\mathrm{Mg} /(\mathrm{Mg}+\mathrm{Fe})$. Abbreviations as in Table 2.
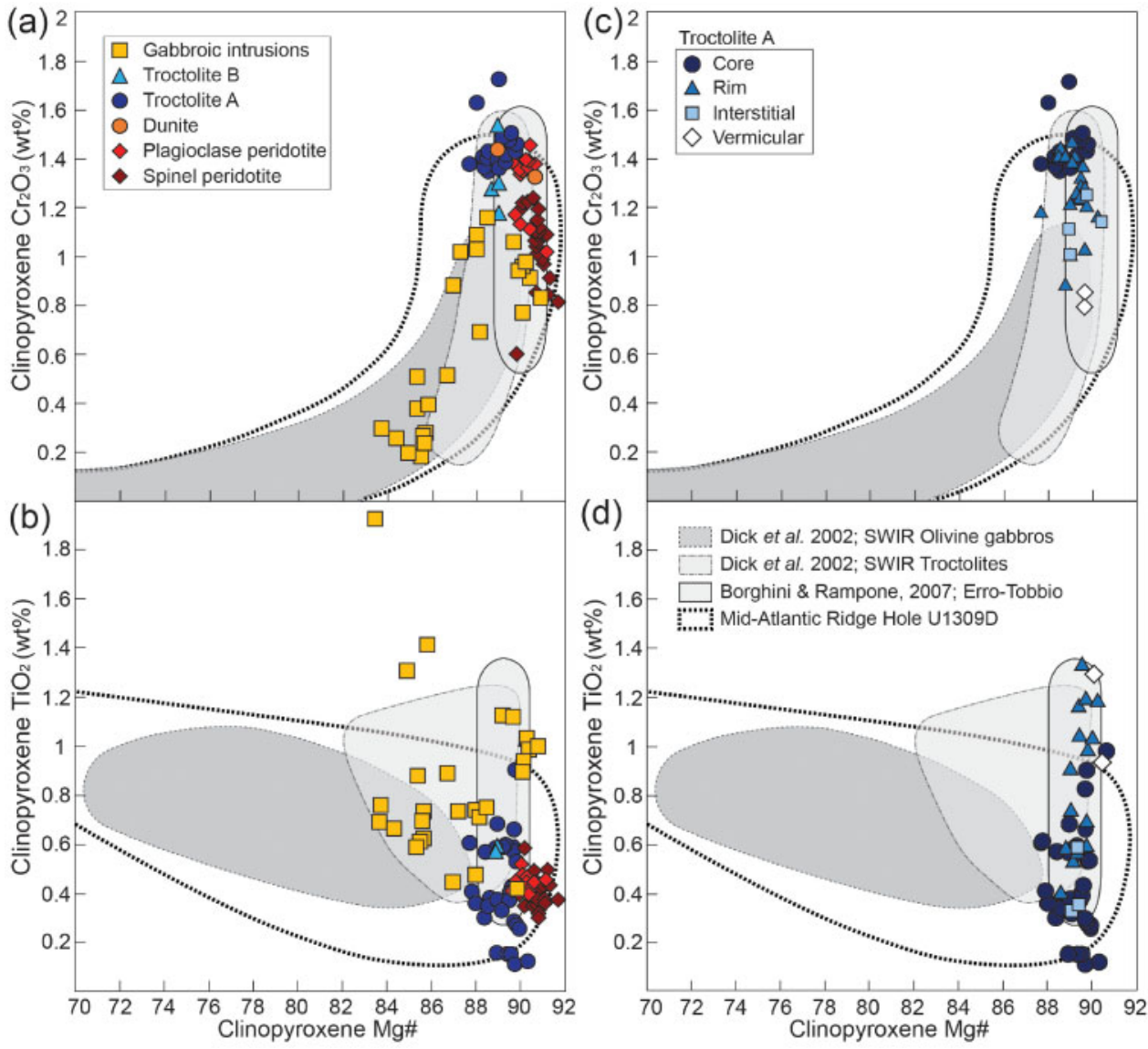

Fig. 11. Major element compositions of clinopyroxene cores $(a, b)$ in all studied samples, plotted against the $\mathrm{Mg}$-number $[=\mathrm{Mg} /$ $(\mathrm{Mg}+\mathrm{Fe})]$, and compositional variability with microstructural site $(\mathrm{c}, \mathrm{d})$ in Troctolite $\mathrm{A} .(\mathrm{a}, \mathrm{c}) \mathrm{Cr}_{2} \mathrm{O}_{3}(\mathrm{wt} \%) ;(\mathrm{b}, \mathrm{d}) \mathrm{TiO}_{2}(\mathrm{wt} \%)$. Compositional fields represent the compositions of olivine gabbros and troctolites from the South-West Indian Ridge, after Dick et al. (2002), olivine-rich troctolites from Erro-Tobbio, after Borghini \& Rampone (2007), and troctolites, olivine gabbros and gabbros from the Mid-Atlantic Ridge Hole U1309D, after Suhr et al. (2008), Drouin et al. (2009), Miller et al. (2009) and Ferrando et al. (2018).

\section{Plagioclase}

Plagioclases in Troctolite A (Table 4) are characterized by low and variable anorthite contents (An $=52.9$ $66.8 \mathrm{~mol} \%$ ) (Fig. 13). The same variability is observed in
Troctolite B, with anorthite contents of 55.1-66.1 mol \%. Plagioclases in gabbroic intrusions show lower anorthite at $51.6-62.7 \mathrm{~mol} \%$. In all samples of Troctolite A and Troctolite $B$, a correlation is observed between the 

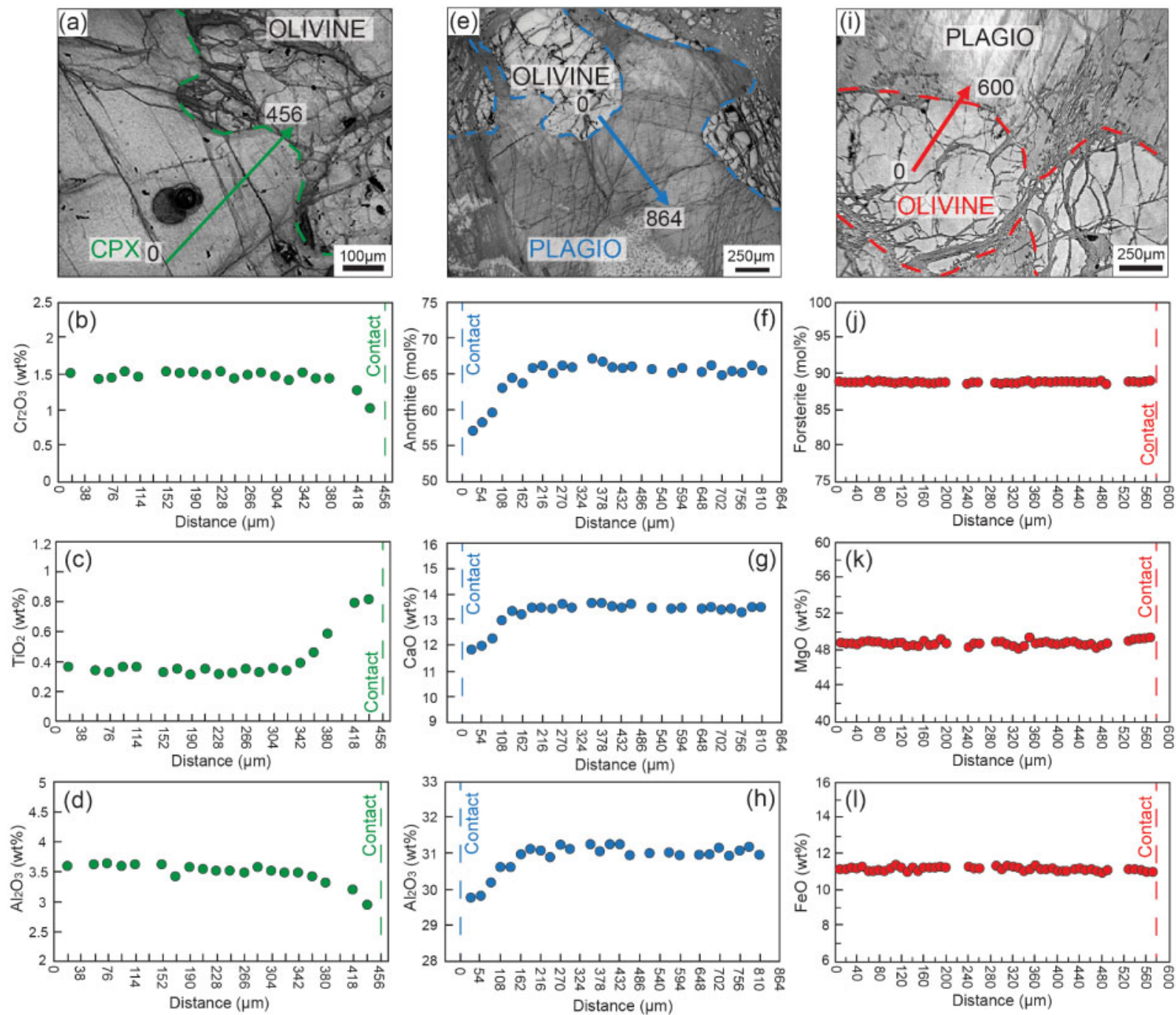

Fig. 12. Reflected light photomicrograph (a) and corresponding clinopyroxene major element profiles (b-d) for Troctolite A. Step size is $19 \mu \mathrm{m}$. (b) $\mathrm{Cr}_{2} \mathrm{O}_{3}$ (wt \%); (c) $\mathrm{TiO}_{2}$ (wt \%); (d) $\mathrm{Al}_{2} \mathrm{O}_{3}$ (wt \%). Total length of the profile is $456 \mu \mathrm{m}$. Reflected light photomicrograph (e) and corresponding plagioclase major element profiles (f-h) for Troctolite A. Step size is $54 \mu \mathrm{m}$. (f) Anorthite content (mol \%); (g) $\mathrm{CaO}$ (wt \%); (h) $\mathrm{Al}_{2} \mathrm{O}_{3}$ (wt \%). Total length of the profile is $864 \mu \mathrm{m}$. Reflected light photomicrograph (i) and corresponding olivine major element profiles (j-I) for Troctolite A. Step size is $10 \mu \mathrm{m}$. (j) Forsterite content (mol \%); (k) MgO (wt \%); (I) FeO (wt \%). Total length of the profile is $600 \mu \mathrm{m}$.

Table 4: Representative major element plagioclase composition

\begin{tabular}{|c|c|c|c|c|c|c|c|c|c|c|c|c|c|c|}
\hline \multirow[b]{2}{*}{$w t \%$} & \multicolumn{2}{|c|}{ Troctolite A } & \multirow{2}{*}{$\begin{array}{l}\text { Wehrlite } \\
\text { apophysis } \\
\text { Core }\end{array}$} & \multicolumn{2}{|c|}{$\begin{array}{l}\text { Troctolite } \\
\text { apophysis }\end{array}$} & \multicolumn{2}{|c|}{ Troctolite B } & \multirow{2}{*}{$\begin{array}{l}\text { Troct. } \\
\text { gabbro } \\
\text { Core }\end{array}$} & \multicolumn{2}{|c|}{ Troct. gabbro } & \multicolumn{2}{|c|}{ Olivine gabbro } & \multicolumn{2}{|c|}{ Olivine gabbro } \\
\hline & Core & Rim & & & $\operatorname{Rim}$ & Core & $\operatorname{Rim}$ & & Core & Rim & Core & $\operatorname{Rim}$ & Core & Rim \\
\hline $\mathrm{SiO}_{2}$ & 52.22 & 54.11 & 52.74 & 52.08 & 54.76 & 51.21 & 52.95 & 52.08 & 53.41 & 53.73 & 53.53 & 55.03 & 54.53 & 54.05 \\
\hline C & & & & & & & & & & & & & & \\
\hline $\mathrm{I}_{2} \mathrm{O}_{3}$ & 30.39 & 29.1 & & 30 & 28 & 30. & 29 & & & & & & & .02 \\
\hline $\mathrm{r}_{2} \mathrm{O}_{3}$ & b.d.l. & b.d.I. & & b.d.I. & b.d.l. & 0.02 & & & b.d.l. & b.d.l. & b.c & b.d & b.d.l. & b.d.I. \\
\hline 0 & 0.16 & 0.15 & & 0.02 & 0.02 & 0.23 & 0.1 & 0.30 & 0.33 & 0.20 & & & 0.27 & 0.30 \\
\hline $\mathrm{lgO}$ & & & & & b.d.l. & b.d.l. & & & & & & & & 0.02 \\
\hline 0 & & & b.c & & b.d.I. & & & & & & & & b.d.I. & b.d.I. \\
\hline & & b.d.I. & & b.d.I. & b.d & & & b.d.l. & b.d.l. & b.c & .d.I. & & 0 & b.d.I. \\
\hline $\mathrm{CaO}$ & 13.35 & 11.25 & 12.78 & 12.79 & $11 \cdot 17$ & $13 \cdot 14$ & 12.15 & 12.71 & 11.84 & 11.39 & $11 \cdot 14$ & & 10.90 & 11.02 \\
\hline $\mathrm{Na}_{2} \mathrm{O}$ & & $5 \cdot 27$ & & $4 \cdot 27$ & $5 \cdot 27$ & 3.99 & & $4 \cdot 25$ & 4.87 & 5.07 & $5 \cdot 16$ & & 5.46 & $5 \cdot 22$ \\
\hline $\mathrm{K}_{2} \mathrm{O}$ & & & & & & & & & & & & & & 0.03 \\
\hline Total & & & & & & & & & & & & & & \\
\hline An & & $54 \cdot 12$ & 61.72 & $62 \cdot 34$ & 53.94 & 64.54 & 59.45 & $62 \cdot 30$ & $57 \cdot 33$ & $55 \cdot 39$ & 54.40 & $52 \cdot 84$ & 52.45 & 53.82 \\
\hline
\end{tabular}

$\mathrm{An}=\mathrm{Ca} /(\mathrm{Ca}+\mathrm{Na})$. Abbreviations as in Table 2. 


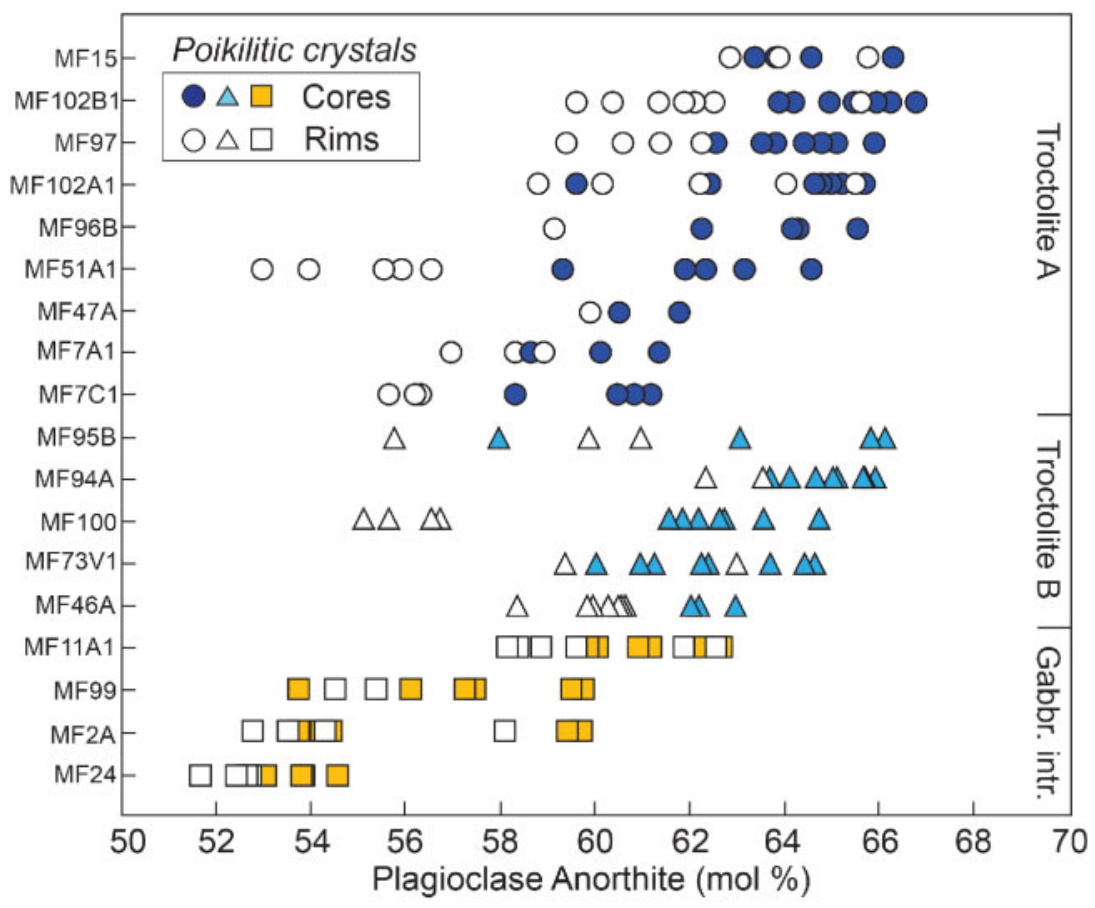

Fig. 13. Range of anorthite contents in plagioclase in Troctolite A, Troctolite $B$ and gabbroic intrusions. Distinction has been made between cores (coloured symbols) and rims (white symbols) of coarse poikilitic plagioclase crystals.

microstructural site and the anorthite content of the analyzed plagioclase crystal. Thin interstitial crystals and rims of large grains systematically show lower anorthite contents than the plagioclase cores (Fig. 13), leading to a variation of anorthite content of up to $10 \mathrm{~mol} \%$ within a single sample, in both Troctolites A and Troctolites B.

Again, these geochemical variations are well observed in major element profiles from core to rim of plagioclase crystals, at the contact with olivine. A progressive decrease in anorthite content (from 66 to $56 \mathrm{~mol} \%$ ), $\mathrm{CaO}$ (from 14 to $12 \mathrm{wt} \%$ ), and $\mathrm{Al}_{2} \mathrm{O}_{3}$ (from 31 to $30 \mathrm{wt} \%$ ) is observed in the profiles towards the rim and the contact with olivine (Fig. 12e-h), as previously documented by Borghini \& Rampone (2007). Therefore, as observed for clinopyroxene, the strong compositional variation reported in single samples of Troctolite $A$ and $B$ (up to $10 \%$ anorthite content; Fig. 13 ) is not due to variations between different crystals, but to the zonation observed at the scale of a single grain (Fig. 12e-h). As documented in the clinopyroxene-olivine profiles, the chemical zoning in plagioclase is observed from $\sim 200 \mu \mathrm{m}$ to the contact with the olivine, irrespective of its textural type (coarse deformed corroded grain or small undeformed granular crystal).

In the gabbroic intrusions, no systematic zoning is observed in plagioclase, and the analyzed range of anorthite contents is mainly observed between samples (Fig. 13), with plagioclase in troctolitic dykes showing higher anorthite contents (MF11A1, MF99, An = 53.8$62.7 \mathrm{~mol} \%$; Table 1) than plagioclase within the olivine gabbro dykes (MF2A, MF24, An $=51.6-54.6 \mathrm{~mol} \%$; Table 1).

\section{Orthopyroxene}

Orthopyroxenes (Table 5) analyzed in evolved gabbroic intrusions have lower Mg-numbers $(\mathrm{Mg \#}=84.53 \mathrm{~mol}$ $\%)$ than the homogeneous orthopyroxene compositions analyzed in the spinel and plagioclase Iherzolites (Mg\# $=89.64-90.54 \mathrm{~mol} \%$ ).

\section{Spinel}

Spinels in spinel Iherzolites (Table 6) exhibit high Mgnumbers $(\mathrm{Mg} \#=66.9-72.8 \mathrm{~mol} \%)$, low Cr-numbers $(\mathrm{Cr} \#=14.2-18.6 \mathrm{~mol} \%)$, and very low $\mathrm{TiO}_{2}$ contents $(0.02-0.16 \mathrm{wt} \%)$, similar to spinel compositions in plagioclase-free peridotites from the South-West Indian Ridge (Seyler et al., 2003). In the gabbroic intrusions, the spinels have low Mg-numbers $(\mathrm{Mg} \#=25 \cdot 2$ $36.1 \mathrm{~mol} \%$ ), and high $\mathrm{Cr}$-numbers ( $\mathrm{Cr} \#=63.6-69.0 \mathrm{~mol}$ $\%)$ and $\mathrm{TiO}_{2}(1.22-1.49 \mathrm{wt} \%)$.

In Troctolite A, dunite and Troctolite B, spinels show Mg-numbers ( $\mathrm{Mg} \#=19.2-55.6 \mathrm{~mol} \%$ ) and $\mathrm{Cr}$-numbers $(\mathrm{Cr} \#=40.5-64.5 \mathrm{~mol} \%)$ intermediate between spinel compositions in the spinel Iherzolites and the gabbroic intrusions, and a negative correlation is observed between the Mg-number and the $\mathrm{Cr}$-number, consistent with spinel compositions in troctolites from the MidAtlantic Ridge (Miller et al., 2009). Some spinels in Troctolite A and Troctolite $\mathrm{B}$, and most of them in the dunite show strong enrichments in $\mathrm{TiO}_{2}(0.79-3.27 \mathrm{wt}$ $\%)$, up to twice the $\mathrm{TiO}_{2}$ concentrations analyzed in 
gabbroic intrusions. The negative correlation between Mg-number and $\mathrm{TiO}_{2}$ concentrations in spinel analyzed in Troctolite A, associated dunites and Troctolite B is consistent with the trend reported for spinels analyzed in troctolites from the Mid-Atlantic Ridge (Miller et al., 2009).

\section{Element partitioning between mineral pairs}

Figure 14a shows the Mg-Fe partitioning between olivine and clinopyroxene in all studied lithotypes. Overall, the studied samples show a positive correlation between forsterite contents in olivine (from Fo $=81.3 \mathrm{~mol}$ $\%$ in gabbroic intrusions to $\mathrm{Fo}=90.5 \mathrm{~mol} \%$ in spinel Iherzolites) and Mg-number in clinopyroxene (from $\mathrm{Mg \#}=83.5 \mathrm{~mol} \%$ in gabbroic intrusions to $\mathrm{Mg \#}=$ $91.6 \mathrm{~mol} \%$ in spinel Iherzolite). This correlation is consistent with the $\mathrm{Mg}-\mathrm{Fe}$ equilibrium lines calculated between olivine and clinopyroxene by Lissenberg \& Dick (2008) $\left[K \mathrm{~d}_{\mathrm{ol} / \mathrm{cpx}}(\mathrm{Fe \#})=1.30\right]$ (Fig. 14a). Pairs of olivine and clinopyroxene cores in Troctolite $A$, dunite, and Troctolite B show compositions ( $\mathrm{Fo}=87.3-89.2 \mathrm{~mol} \%$, $\mathrm{Mg} \#=87.7-91 \mathrm{~mol} \%)$ that are intermediate between those of the Mg-rich pairs analyzed in spinel and plagioclase Iherzolites (Fo $=89.5-90.5 \mathrm{~mol} \%$, Mg\# $=89.6-$

Table 5: Representative major element orthopyroxene composition

\begin{tabular}{|c|c|c|c|c|}
\hline \multirow[b]{2}{*}{$w t \%$} & \multirow{2}{*}{$\begin{array}{l}\text { Spinel } \\
\text { Iherzolite } \\
\text { Core }\end{array}$} & \multicolumn{2}{|c|}{ Plagioclase Iherzolite } & \multirow{2}{*}{$\begin{array}{l}\text { Olivine } \\
\text { gabbro } \\
\text { Core }\end{array}$} \\
\hline & & Core & Rim & \\
\hline $\mathrm{SiO}_{2}$ & 55.40 & $56 \cdot 18$ & 55.43 & 54.83 \\
\hline $\mathrm{TiO}_{2}$ & 0.10 & 0.24 & 0.21 & 0.28 \\
\hline $\mathrm{Al}_{2} \mathrm{O}_{3}$ & 4.88 & $2 \cdot 39$ & 2.63 & $2 \cdot 30$ \\
\hline $\mathrm{Cr}_{2} \mathrm{O}_{3}$ & 0.73 & 0.65 & 0.82 & 0.19 \\
\hline $\mathrm{FeO}$ & $6 \cdot 26$ & $6 \cdot 27$ & 5.95 & 10.05 \\
\hline $\mathrm{MgO}$ & $32 \cdot 10$ & $32 \cdot 64$ & 31.69 & 30.82 \\
\hline $\mathrm{MnO}$ & 0.15 & 0.08 & 0.14 & 0.22 \\
\hline $\mathrm{NiO}$ & 0.08 & 0.07 & 0.10 & b.d.l. \\
\hline $\mathrm{CaO}$ & 0.85 & 1.52 & 3.22 & 1.33 \\
\hline $\mathrm{Na}_{2} \mathrm{O}$ & 0.03 & 0.01 & 0.03 & b.d.I. \\
\hline Total & $100 \cdot 57$ & 100.05 & $100 \cdot 22$ & $100 \cdot 02$ \\
\hline Mg\# & $90 \cdot 14$ & $90 \cdot 27$ & 90.47 & 84.53 \\
\hline
\end{tabular}

$\mathrm{Mg} \#=\mathrm{Mg} /(\mathrm{Mg}+\mathrm{Fe})$.
$91.6 \mathrm{~mol} \%)$ and the most evolved compositions in the gabbroic intrusions ( $\mathrm{Fo}=81 \cdot 3-89.2 \mathrm{~mol} \%, \mathrm{Mg \#}=83.5-$ $90.8 \mathrm{~mol} \%)$.

Figure 14b shows anorthite and forsterite contents ( $\mathrm{mol} \%$ ) in plagioclase-olivine core pairs in Troctolite A, Troctolite $\mathrm{B}$ and the gabbroic intrusions. Within the troctolitic body, plagioclase-olivine pairs show significant variations in anorthite content of plagioclase cores (An $=58.4-66.8 \mathrm{~mol} \%)$ at constant forsterite composition in associated olivines $(87.3-89.2 \mathrm{~mol} \%)$, similar to what was reported at the easternmost South-West Indian Ridge $\left(61-67^{\circ} \mathrm{E}\right)$ (Paquet et al., 2016). By contrast, the gabbroic intrusions define a trend of evolution characterized by a positive correlation between anorthite content in plagioclase cores and forsterite content in olivine (from $\mathrm{An}_{51.6}-\mathrm{Fo}_{81.3}$ to $\mathrm{An}_{62.7}-\mathrm{Fo}_{89.2}$ ). This trend in the gabbroic intrusions shows a similar slope to the compositional arrays defined by olivine gabbros in the oceanic lower crust from the South-West Indian Ridge (Hole 735B: Dick et al., 2002), Mid-Atlantic Ridge (Ross \& Elthon, 1997; Lissenberg \& Dick, 2008; Suhr et al., 2008; Drouin et al., 2009; Miller et al., 2009), and Pineto ophiolite (Sanfilippo \& Tribuzio, 2013), but shifted towards higher forsterite contents of olivine (Fig. 14b).

Clinopyroxene Mg-number (mol \%) shows similar correlations with plagioclase anorthite (mol \%) content (Fig. 14c), with a relatively constant Mg-number in Troctolite $A$ and Troctolite $B(\mathrm{Mg} \#=87.7-91.0 \mathrm{~mol} \%)$ at varying anorthite content $(A n=55 \cdot 1-67.0 \mathrm{~mol} \%)$, similar to mineral compositions analyzed at the easternmost South-West Indian Ridge $\left(61-67^{\circ} \mathrm{E}\right.$ ) (Paquet et al., 2016). The gabbroic intrusions show a positive correlation between $\mathrm{Mg}$-number in clinopyroxene and anorthite content in plagioclase (from $\mathrm{An}_{51.6}-\mathrm{Mg} \#_{83.7}$ to $\left.\mathrm{An}_{62.7}-\mathrm{Mg} \#_{90.1}\right)$. The slope defined by the anorthite-Mgnumber (cpx) covariation in the gabbroic intrusions is consistent with the trends documented in the oceanic gabbro suites at the Mid-Atlantic Ridge (Ross \& Elthon, 1997; Lissenberg \& Dick, 2008; Suhr et al., 2008; Drouin et al., 2009; Miller et al., 2009; Ferrando et al., 2018), South-West Indian Ridge (Dick et al., 2002), and in the

Table 6: Representative major element spinel composition

\begin{tabular}{|c|c|c|c|c|c|c|}
\hline$w t \%$ & Spinel Iherz. & Dunite & Troct. A & Troct. apo. & Troct. B & Troct. gabbro \\
\hline $\mathrm{SiO}_{2}$ & b.d.I. & 0.03 & 0.02 & b.d.l. & 0.05 & b.d.I. \\
\hline $\mathrm{TiO}_{2}$ & 0.07 & 2.91 & 1.66 & 1.27 & 2.01 & 1.39 \\
\hline $\mathrm{Al}_{2} \mathrm{O}_{3}$ & 53.68 & $15 \cdot 19$ & 17.90 & $16 \cdot 33$ & 21.41 & $12 \cdot 89$ \\
\hline $\mathrm{Cr}_{2} \mathrm{O}_{3}$ & $14 \cdot 82$ & 38.02 & 35.94 & 38.79 & 35.93 & $42 \cdot 77$ \\
\hline $\mathrm{Fe}_{2} \mathrm{O}_{3}$ & 1.03 & 11.65 & b.d.I. & b.d.l. & 7.83 & b.d.I. \\
\hline $\mathrm{FeO}$ & $12 \cdot 78$ & 23.60 & 36.35 & 35.93 & 23.20 & 35.89 \\
\hline $\mathrm{MnO}$ & b.d.I. & b.d.I. & 0.23 & 0.03 & b.d.I. & 0.38 \\
\hline $\mathrm{NiO}$ & b.d.I. & b.d.l. & 0.27 & 0.02 & b.d.I. & 0.12 \\
\hline $\mathrm{MgO}$ & $18 \cdot 31$ & 8.76 & $6 \cdot 82$ & 7.29 & 8.93 & $6 \cdot 79$ \\
\hline $\mathrm{CaO}$ & b.d.I. & 0.01 & 0.03 & b.d.I. & 0.01 & b.d.I. \\
\hline Total & 100.69 & $100 \cdot 17$ & 99.23 & 99.67 & 99.41 & $100 \cdot 29$ \\
\hline $\mathrm{Cr} \#$ & 0.16 & 0.63 & 0.57 & 0.61 & 0.53 & 0.69 \\
\hline Mg\# & 0.70 & 0.31 & 0.25 & 0.27 & 0.34 & 0.25 \\
\hline
\end{tabular}

$\mathrm{Mg} \#=\mathrm{Mg} /(\mathrm{Fe}+\mathrm{Mg}) ; \mathrm{Cr} \#=\mathrm{Cr} /\left(\mathrm{Cr}+\mathrm{Al}+\mathrm{Fe}^{3+}\right)$. Abbreviations as in Table 2. 

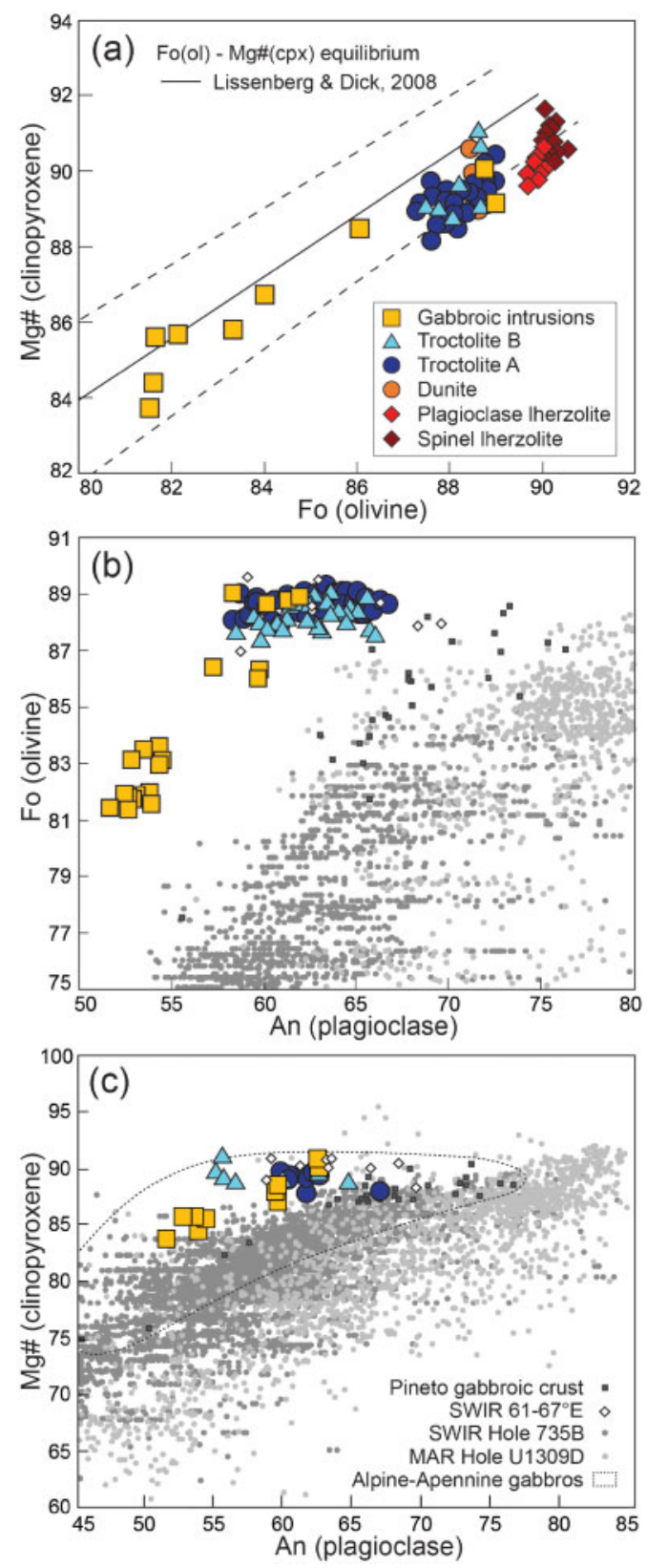

Fig. 14. (a) Olivine-clinopyroxene cores $\mathrm{Mg} \#[=\mathrm{Mg} /(\mathrm{Mg}+\mathrm{Fe})$ (mol \%)] correlation in the studied samples, compared with theoretical $\mathrm{Fe}-\mathrm{Mg}$ equilibrium between olivine and clinopyroxene, after Lissenberg \& Dick (2008). The dashed lines represent the calculated olivine-clinopyroxene equilibrium line assuming an uncertainty of \pm 0.02 on the mineral-melt partition coefficients. (b) Anorthite content ( $\mathrm{mol} \%$ ) in plagioclase cores vs forsterite content $(\mathrm{mol} \%)$ in olivine cores in olivine-plagioclase pairs from the studied Troctolite A, Troctolite B and gabbroic intrusions. (c) Anorthite content (mol \%) in plagioclase cores vs Mg-number ( $\mathrm{mol} \%$ ) in clinopyroxene cores in plagioclaseclinopyroxene pairs from the studied Troctolite A, Troctolite B and gabbroic intrusions. Compositional trends and fields represent olivine-plagioclase and olivine-clinopyroxene pairs in olivine gabbros and troctolites from the South-West Indian Ridge (Hole 735B: Dick et al., 2002; 61-67': Paquet et al., 2016), the Mid-Atlantic Ridge Hole U1309D (Ross \& Elthon, 1997; Lissenberg \& Dick, 2008; Suhr et al., 2008; Drouin et al., 2009; Miller et al., 2009), the Pineto gabbroic crust (Sanfilippo \& Tribuzio, 2013), and the Alpine-Apennine ophiolites (Hébert et al., 1989; Tribuzio et al., 1999; Montanini et al., 2008; Sanfilippo \& Tribuzio, 2013).
Pineto gabbroic crust (Sanfilippo \& Tribuzio, 2013), but shifted towards higher Mg-number values of clinopyroxene (Fig. 14c). Also shown is the compositional field of Alpine-Apennine troctolites, olivine gabbros and gabbros (Hébert et al., 1989; Tribuzio et al., 1999; Montanini et al., 2008; Sanfilippo \& Tribuzio, 2013), characterized by lower anorthite contents in plagioclase at a given $\mathrm{Mg}$-number in clinopyroxene, compared with oceanic gabbroic series [Fig. 14c; South-West Indian Ridge (SWIR) Hole 735B: Dick et al., 2002; Mid-Atlantic Ridge (MAR) Hole U1309D: Ross \& Elthon, 1997; Lissenberg \& Dick, 2008; Suhr et al., 2008; Drouin et al., 2009; Miller et al., 2009; Ferrando et al., 2018].

\section{DISCUSSION}

\section{Replacive origin of Troctolite A}

As documented in previous studies and herein, the Erro-Tobbio troctolitic body crosscuts the host impregnated plagioclase Iherzolites and associated pyroxenite banding (Fig. 4; Borghini \& Rampone, 2007; Borghini et al., 2007; Rampone et al., 2016), includes dunite pods, and develops wehrlite and troctolite apophyses into the mantle plagioclase Iherzolites (Fig. 2a). Troctolite A shows a strong textural complexity with the occurrence of two distinct types of olivine within individual samples (Fig. 6a-d); that is, millimetre-size undeformed granular olivine grains (Fig. $5 a$ and b) and coarse (up to centimetre-size) deformed and corroded crystals (Fig. 5c and d). As inferred for oceanic settings during the formation of olivine-rich troctolites (Suhr et al., 2008; Drouin et al., 2010), Rampone et al. (2016) interpreted the textural complexity of the Erro-Tobbio troctolites as the result of melt-rock interactions leading to the dissolution of the olivine matrix and crystallization of interstitial plagioclase. Although they were not able to distinguish two olivine generations in a specific troctolite sample, they inferred that the millimetre-size undeformed granular olivine grains could represent a second generation of 'olivine 2', whether of magmatic origin or representing disrupted coarse olivine grains. Detailed EBSD analysis (size, shape, misorientation; Fig. 6) allows us to interpret the coarse deformed and corroded olivine as the pre-existing, possibly mantle relict 'olivine 1 '. The occurrence of coarse corroded grains almost disrupted into several granular olivines (Fig. $5 \mathrm{c}$ ) suggests that most of the small undeformed olivine grains were formed after extensive corrosion and disruption of the coarse pre-existing olivines. This process of textural evolution of the olivine matrix, during progressive melt-rock interaction and replacive formation of olivine-rich troctolites, has been previously inferred in oceanic settings (Suhr et al., 2008; Drouin et al., 2010; Ferrando et al., 2018) and recently demonstrated in an ophiolitic setting at the Mt. Maggiore peridotitic body (Basch et al., 2018).

At the scale of the sample, Troctolite $A$ is also characterized by variations in the texture of the olivine matrix (taken as a whole, olivine 1 +olivine 2), between 
samples characterized by plagioclase-free dunitic aggregates surrounded by interstitial phases (Fig. 6a-c), and disaggregated samples where single olivines are completely embedded in poikilitic plagioclase (Fig. 6d). This textural variability is well correlated with a change in olivine CPO. The olivine matrix of Troctolite A, characterized by plagioclase-free dunitic aggregates, shows an axial-[100] fabric (Fig. 8), similar to that of the spinel Iherzolites and dunite pods. This axial-[100] CPO is typically reported in natural peridotites deformed under asthenospheric conditions (e.g. Tommasi et al., 2000; Le Roux et al., 2008; Soustelle et al., 2009), and indicates that plastic deformation was related to dislocation creep with joint activation of the (010)[100] and (001)[100] slip systems, the most easily activated at high-temperature conditions $\left(1100-1200^{\circ} \mathrm{C}\right.$ ) (Ben Ismail \& Mainprice, 1998; Tommasi et al., 2000; Karato et al., 2008; Drouin et al., 2010; Higgie \& Tommasi, 2012). The samples characterized by a disaggregated olivine matrix, embedded in poikilitic plagioclase, show scattered orientations of [100] and [010] olivine axes, and a stronger concentration of the [001] axis (Fig. 8). Such olivine CPOs have been previously reported in zones of melt accumulation in the Oman Moho Transition Zone (Ceuleneer \& Rabinowicz, 1992; Boudier \& Nicolas, 1995; Jousselin et al., 1998; Dijkstra et al., 2002; Higgie \& Tommasi, 2012) and during the replacive formation of olivine-rich troctolites at the Atlantis Massif (Drouin et al., 2010). It has been interpreted as a loss of cohesion of the solid matrix during impregnation at high melt/rock ratios (20-40\% melt fraction; Rosenberg \& Handy, 2005). Melt-rock interaction microstructures, indicating the corrosion of the pre-existing olivine matrix, together with the preservation of dunitic pods within the host Troctolite A (Figs $2 d$ and 4) and the correlation between the observed texture of the olivine matrix and its CPO (Fig. 8), suggest a replacive formation of Troctolites A. We infer that they formed from a mantle dunite protolith (itself preserving the mantle precursor axial-[100] CPO), after reactive percolation of a MORB-type melt at variable melt/rock ratios (Fig. 15). The disaggregation of the olivine matrix associated with the loss of the olivine axial-[100] CPO are indicative of high instantaneous melt/rock ratios $(>20-40 \%$; Rosenberg \& Handy, 2005), whereas the samples preserving the mantle olivine CPO indicate a reactive percolation at lower melt/rock ratios (Fig. 15). Texture and CPO analyses, together with the occurrence of preserved dunitic pods within Troctolite $A$, thus indicate that Troctolite A is probably the replacive product of reactive percolation and impregnation of a pristine dunitic matrix by melts crystallizing plagioclase and minor clinopyroxene.

Peculiar geochemical compositional trends for the rock-forming minerals, not consistent with a simple fractional crystallization process, support the replacive origin of Troctolites A. Despite strong variations in olivine modal compositions (from $55 \mathrm{vol}$. \% in troctolites to 97 vol. \% in dunitic pods), olivines and clinopyroxenes
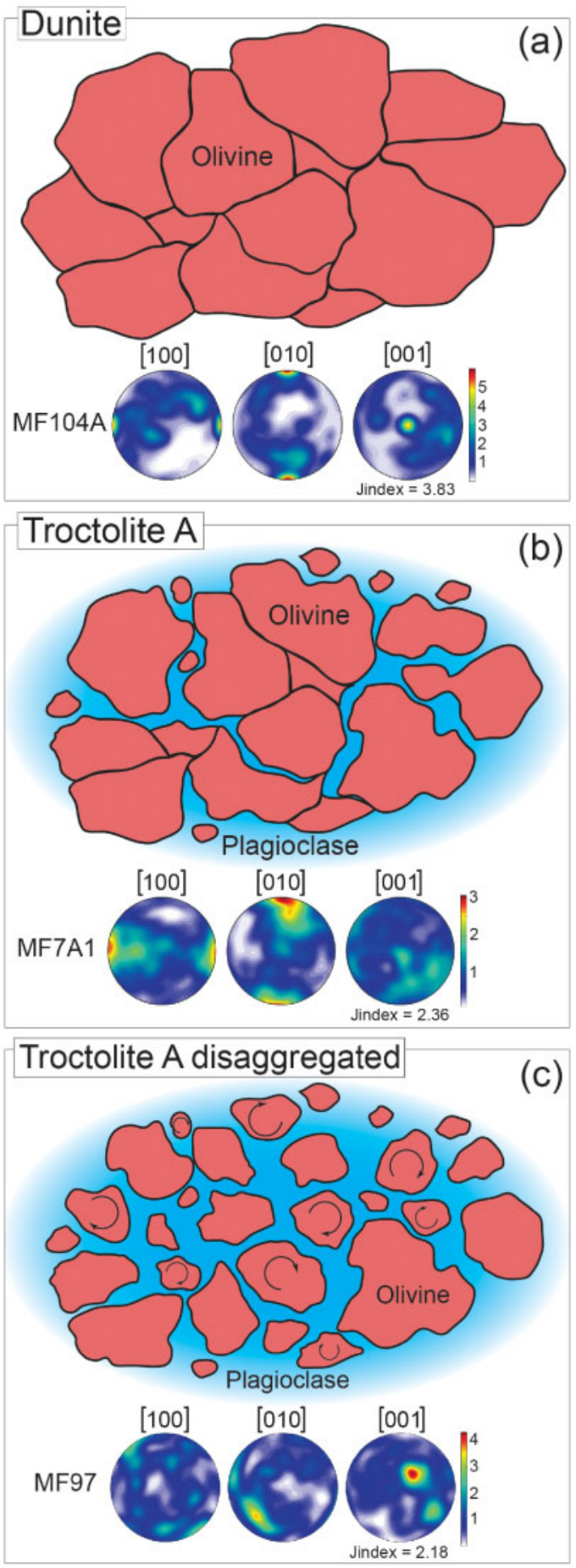

Fig. 15. Interpretative sketches of the evolution of the olivine textures and associated CPOs during progressive olivine-dissolving, plagioclase-crystallizing melt-rock interaction and replacive formation of Troctolite $A$. (a) Coarse-grained dunite protolith showing an axial [100] olivine CPO; (b) Troctolite A impregnated at a low melt-rock ratio, and thus preserving dunitic aggregates and axial [100] olivine CPO; (c) disaggregated Troctolite A, impregnated at high instantaneous meltrock ratios. The arrows within small olivine grains represent the loss of cohesion of the solid matrix leading to the free rotation of the grains and randomization of the olivine CPO. CPO represented as one-point-per-grain equal-area, lower hemisphere stereographic projections. The colour bar is scaled to the maximum concentration of the three crystallographic axes. J-index refers to the fabric strength. 
in the dunite and Troctolite $\mathrm{A}$ show a narrow range of composition (Fo $=88.2-89.1 \mathrm{~mol} \%$; Figs 10a and 14b; $\mathrm{Mg} \#=89-91 \mathrm{~mol} \%$; Fig. 14c). These constant compositions of the mafic minerals (forsterite in olivine and Mgnumber in clinopyroxene) are coupled with significant within-sample variations in plagioclase anorthite contents (An $=52.9-66.8 \mathrm{~mol} \%$; Fig. 14a and b), and therefore do not follow the compositional trends of fractional crystallization defined by the oceanic gabbroic sequences (South-West Indian Ridge, Dick et al., 2002; MidAtlantic Ridge, Ross \& Elthon, 1997; Lissenberg \& Dick, 2008; Suhr et al., 2008; Drouin et al., 2009; Miller et al., 2009). These peculiar compositional trends (Fig. 14a and b) are indicative of the buffering of the melt Mgnumber by olivine-dissolving, reactive porous flow percolation (e.g. Collier \& Kelemen, 2010; Sanfilippo et al., 2016b; Borghini et al., 2018). Mineral compositions in Troctolite A are similar to those documented in the amagmatic easternmost South-West Indian Ridge troctolites and olivine gabbros $\left(61-67^{\circ} \mathrm{E}\right.$; Paquet et al., 2016). These peculiar mineral chemistry covariations were attributed to melt-rock interaction processes involving olivine and orthopyroxene dissolution by a percolating Na-rich basic melt, and subsequent crystallization of plagioclase and clinopyroxene.

\section{Thermodynamic model of olivine-consuming re- active crystallization}

To better constrain and quantify the role of reactive crystallization in the formation of the peculiar An-Fo and $\mathrm{An}-\mathrm{Mg \#}$ compositional trends in the Erro-Tobbio troctolitic body (Fig. 14a and b), we performed an assimilation-fractional crystallization (AFC) geochemical modelling calculation, assuming variable dissolved mass of olivine and concomitant melt crystallization, using the pMELTS thermodynamic program (Ghiorso et al., 2002). This model aims at reproducing the diffuse reactive percolation of a high-temperature melt $\left(1270^{\circ} \mathrm{C}\right)$ into the shallow lithospheric mantle. Based on mineral-mineral partitioning, Rampone et al. (2016) documented a high temperature of equilibration $\left(>1100-1200^{\circ} \mathrm{C}\right)$ in both troctolites and host peridotites. The interaction process thus occurred at relatively high mantle temperatures.

The Erro-Tobbio ultramafic body does not include any basaltic intrusions, precluding direct information on the Troctolite A parental melt composition. However, a few unaltered primitive basaltic intrusions [loss on ignition (LOI) $<2 \%$; Mg\# $>70 \mathrm{~mol} \%$ ] have been documented in the Alpine-Apennine ophiolites. The initial melt composition adopted is a primitive MORB-type basalt ( $\mathrm{Mg} \#=70.75 \mathrm{~mol} \%$ ) associated with the Pineto gabbroic suite (Saccani et al., 2008; Alpine ophiolite), the composition of which is given in Table 7. This primitive melt is characterized by a relatively low $\mathrm{Ca} / \mathrm{Na}$ ratio $(\mathrm{Ca} \#=61.54 \mathrm{~mol} \%$ ), most probably as the result of low degrees of mantle melting (Klein \& Langmuir, 1987; Montanini et al., 2008; Saccani et al.,
2008; Renna et al., 2018), similar to what was described at the easternmost South-West Indian Ridge (Ca\# = 55$60 \mathrm{~mol} \%$; Paquet et al., 2016). Such an Na-rich parental melt composition is consistent with the AlpineApennine compositional field of gabbroic rocks (Fig. 14c; Hébert et al., 1989; Tribuzio et al., 1999; Montanini et al., 2008; Sanfilippo \& Tribuzio, 2013), showing more $\mathrm{Na}$-rich plagioclase compositions (at a given Mg-number in clinopyroxene) than the oceanic gabbroic series at the South-West Indian Ridge and Mid-Atlantic Ridge (Fig. 14c).

We modelled isobaric ( $P=4 \mathrm{kbar})$ reactive fractional crystallization of the primitive MORB melt, cooling in steps of $5^{\circ} \mathrm{C}$ while dissolving a fixed mass of olivine $\left(0 \mathrm{~g}, 1 \mathrm{~g}, 2 \mathrm{~g}, 3 \mathrm{~g}\right.$ per $100 \mathrm{~g}$ of melt) per $1^{\circ} \mathrm{C}$ of cooling (Fig. 16). Similar models of reactive crystallization using the pMELTS thermodynamic program (Ghiorso et al., 2002) have been previously performed by Collier \& Kelemen (2010) and Sanfilippo et al. (2016), involving the assimilation of mantle Iherzolite at $6 \mathrm{kbar}$. In the Erro-Tobbio, Troctolite A includes decimetre-size dunitic pods (Fig. 2d) preserved from melt impregnation, and no mantle pyroxene relict is found in any dunite or troctolite sample. This suggests that the protolith of the Erro-Tobbio troctolite was a dunite. Microstructures in Troctolite A indicate the late crystallization of poikilitic clinopyroxene in minor proportions (Table 1; Fig. 5b), therefore suggesting relatively low crystallization pressures $(<7 \mathrm{kbar})$, leading to the late saturation of clinopyroxene on a MORB-type melt liquid line of descent (Husen et al., 2016). Based on field and microstructural observations, and previous geobarometric estimates within Troctolite A (3-5 kbar; Borghini et al., 2007), we decided to model the dissolution of $100 \%$ olivine $\mathrm{Fo}_{89}$ (olivine composition in the dunite pods) at variable assimilation rates (see below) during a reactive fractional crystallization process occurring at 4 kbar. Recent experimental work (Borghini et al., 2018; Francomme, 2018) demonstrated the possible replacive formation of an olivine-rich troctolite from a dunite protolith and the efficient buffer of the melt composition towards high Mg-numbers by olivine assimilation. They also demonstrated that the reactivity of a melt saturated in olivine (AH6; Husen et al., 2016) with a dunitic matrix of $\mathrm{Fo}_{90}$ is driven by the chemical disequilibrium between the olivine forming the dunitic matrix (more forsteritic) and the olivine in equilibrium with the melt (see also Liang, 2003). The partial dissolution of the dunitic matrix is thus associated with the precipitation of an olivine of different composition that is in equilibrium with the modified melt.

Figure 16 shows the computed crystal line of descent of olivine, plagioclase and clinopyroxene, and Supplementary Data Table S6 reports the evolution of the melt and mineral compositions during fractional and reactive crystallization. The computed crystallization order is olivine-plagioclase-clinopyroxene, as expected from the crystallization of a MORB melt at low pressures ( $<7 \mathrm{kbar}$; Bender et al., 1978; Husen et al., 
Table 7: Input and output melt compositions of pMELTS numerical simulations of reactive and fractional crystallization

\begin{tabular}{|c|c|c|c|c|c|c|c|c|c|c|c|c|c|c|c|}
\hline$w t \%$ & $\mathrm{SiO}_{2}$ & $\mathrm{TiO}_{2}$ & $\mathrm{Al}_{2} \mathrm{O}_{3}$ & $\mathrm{Fe}_{2} \mathrm{O}_{3}$ & $\mathrm{FeO}$ & $\mathrm{MnO}$ & $\mathrm{MgO}$ & $\mathrm{CaO}$ & $\mathrm{Na}_{2} \mathrm{O}$ & $\mathrm{K}_{2} \mathrm{O}$ & Total & Mg\# & Ca\# & $\begin{array}{l}\text { Liquidus } \\
\text { temperature }\left({ }^{\circ} \mathrm{C}\right)\end{array}$ & $\Delta T_{\text {liq }}$ \\
\hline Initial melt* & 49.93 & 1.21 & 16.85 & 0.87 & 7.01 & 0.13 & 9.5 & 10.45 & 3.61 & 0.03 & 99.59 & $70 \cdot 75$ & 61.54 & 1261 & 0 \\
\hline $5 \mathrm{~g}$ assimilation ${ }^{\dagger}$ & 49.5 & $1 \cdot 16$ & 16.05 & 0.85 & $7 \cdot 11$ & 0.13 & 11.4 & 9.95 & 3.44 & 0.03 & 99.62 & 74.08 & 61.51 & 1297 & 36 \\
\hline $10 \mathrm{~g}$ assimilation ${ }^{\dagger}$ & $49 \cdot 11$ & $1 \cdot 1$ & $15 \cdot 32$ & 0.84 & $7 \cdot 21$ & 0.12 & $13 \cdot 12$ & 9.50 & 3.28 & 0.03 & 99.63 & $76 \cdot 43$ & 61.55 & 1322 & 61 \\
\hline $15 \mathrm{~g}$ assimilation $^{\dagger}$ & 48.75 & 1.05 & 14.65 & 0.83 & $7 \cdot 3$ & 0.12 & 14.7 & 9.09 & 3.14 & 0.03 & 99.66 & $78 \cdot 21$ & 61.53 & 1344 & 83 \\
\hline Modified melt ${ }^{\ddagger}$ & $52 \cdot 81$ & 1.94 & $15 \cdot 82$ & 0.77 & 5.50 & 0.00 & 8.03 & $10 \cdot 68$ & 4.41 & 0.04 & $100 \cdot 0$ & $72 \cdot 24$ & $57 \cdot 23$ & 1222 & - \\
\hline
\end{tabular}

$\mathrm{Mg} \#=\mathrm{Mg} /(\mathrm{Mg}+\mathrm{Fe}) ; \mathrm{Ca} \#=\mathrm{Ca} /(\mathrm{Ca}+\mathrm{Na}) ;-\Delta T_{\text {liq }}=T_{\text {liq }}$ (modif) $-T_{\text {liq }}$ (initial). Major elements in wt $\%$.

* Initial primitive melt composition used for fractional and reactive crystallization modelling, after Saccani et al. (2008).

${ }^{\dagger}$ Melt composition and liquidus temperature after assimilation of 5,10 and $15 \mathrm{~g}$ of olivine during $5^{\circ} \mathrm{C}$ cooling.

${ }^{\ddagger}$ Melt composition modified after reactive crystallization process, used as initial melt for fractional crystallization process of the olivine gabbros.

2016). The starting melt composition is in equilibrium with an olivine $\mathrm{Fo}=87 \mathrm{~mol} \%$, but at increasing dissolution rates (from 0 to $3 \mathrm{~g}^{\circ} \mathrm{C}^{-1}$ of cooling) the equilibrium forsterite content in olivine and the Mg-number in clinopyroxene are progressively buffered by the composition of the dissolved olivine ( $\mathrm{Fo}=89 \mathrm{~mol} \%$ ). It is worth noting that this extensive olivine dissolution implies the crystallization of new olivine crystals and/or recrystallization of the olivine matrix throughout the reactive percolation process (Supplementary Data Table S6; Liang, 2003). Supplementary Data Table S6 shows that even at high dissolution rates $\left(3 \mathrm{~g}^{\circ} \mathrm{C}^{-1}\right.$ of cooling), the early stages of reactive crystallization $\left(1270-1260^{\circ} \mathrm{C}\right)$, characterized by crystallization of olivine only, do not involve a significant variation in melt mass (olivine dissolved/olivine crystallized $=0.88-1 \cdot 12$ ). This supports the dissolution-reprecipitation of the pre-existing dunitic matrix. Moreover, given that in Troctolite A, most small undeformed olivine crystals embedded in poikilitic plagioclase and clinopyroxene are the result of extensive corrosion and disruption of large olivine grains (and therefore do not represent newly formed magmatic olivines; see Discussion), it is likely that olivine precipitation mostly consisted in the recrystallization of the pre-existing olivine rims (Liang, 2003; Morgan \& Liang, 2005). However, no compositional variation was found between the olivine cores (possibly relict) and rims (possibly recrystallized) (Fig. 12i-I). This is presumably due to the similar composition of the pre-existing ( $\mathrm{Fo}=89 \mathrm{~mol} \%$; Table 2 ) and recrystallized olivine ( $\mathrm{Fo} \approx 88 \mathrm{~mol} \%$; Supplementary Data Table S6), and to the fast $\mathrm{Mg}-\mathrm{Fe}$ diffusion rates of olivine at magmatic temperatures ( $t_{\text {equ }}<200$ years for $3 \mathrm{~mm}$ radius; Dohmen \& Chakraborty, 2007; Ferrando et al., 2018).

During the reactive fractional crystallization process, the anorthite contents in plagioclase evolve freely towards lower values along the crystal line of descent (Fig. 16), leading to the reactive crystallization trends of variation previously described by Collier \& Kelemen (2010) and Sanfilippo et al. (2016) (decreasing anorthite contents in plagioclase at constant forsterite contents in olivine and Mg-number in clinopyroxene). Crystal lines of descent at high rates of olivine dissolution during reactive crystallization (from 2 to $3 \mathrm{~g}^{\circ} \mathrm{C}^{-1}$ of cooling) fit well the analyzed peculiar trends of mineral covariation in the Erro-Tobbio troctolites and confirm the strong implication of olivine-dissolving reactive porous flow processes in the formation of the host Troctolite A from a pre-existing dunite (Figs 15 and 16).

Clinopyroxene cores from Troctolite $A$ have high $\mathrm{Cr}_{2} \mathrm{O}_{3}$ contents (Fig. 11a and c), similar to those described in oceanic gabbroic rocks analyzed at the Mid-Atlantic Ridge (Lissenberg \& Dick, 2008; Lissenberg \& MacLeod, 2016; Ferrando et al., 2018), easternmost South-West Indian Ridge (Paquet et al., 2016) and Godzilla Megamullion (Sanfilippo et al., 2016b), and in olivine-rich troctolites from the Internal Liguride ophiolite (Renna \& Tribuzio, 2011; Renna et al., 2016). Although pMELTS (Ghiorso et al., 2002) does not allow the $\mathrm{Cr}_{2} \mathrm{O}_{3}$ compositional modelling of clinopyroxene, the process of partial dissolution and recrystallization of a dunite (olivine + spinel) described above could well explain the $\mathrm{Cr}_{2} \mathrm{O}_{3}$ enrichments observed in the clinopyroxene cores (Fig. 11a and c). Within Troctolite A, interstitial minerals often develop embayments on corroded relicts of spinel grains. This indicates partial dissolution of $\mathrm{Cr}$-rich spinel ( $\mathrm{Cr} \#=55-65$ in the dunite; Table 6) together with the olivine during the reactive melt percolation process, as was previously described in oceanic settings and in the Internal Liguride ophiolites during replacive formation of olivine-rich gabbroic rocks (Lissenberg \& Dick, 2008; Renna \& Tribuzio, 2011; Lissenberg \& MacLeod, 2016; Paquet et al., 2016; Renna et al., 2016; Sanfilippo et al., 2016b; Ferrando et al., 2018). The corrosion of spinel leads to $\mathrm{Cr}_{2} \mathrm{O}_{3}$ enrichments in the reacting melt, therefore explaining the $\mathrm{Cr}$ rich compositions of clinopyroxenes crystallized from the percolating modified melt (Fig. 11a). The corrosion of spinel during impregnation of the dunite and the $\mathrm{Cr}$ rich character of the melt are also suggested within Troctolite $\mathrm{A}$ by the crystallization of numerous finegrained euhedral spinels associated with the poikilitic plagioclase (Fig. 6d).

\section{Magmatic origin of Troctolite $B$}

In Troctolite B, pseudo-tabular bodies crosscut the Troctolite A structures, with irregular to straight contacts with the host troctolite (Figs 2c, 3a, b and 4). Troctolite B has a lower modal content of olivine (from 45 to 60 vol. \% modal olivine), with respect to the host 


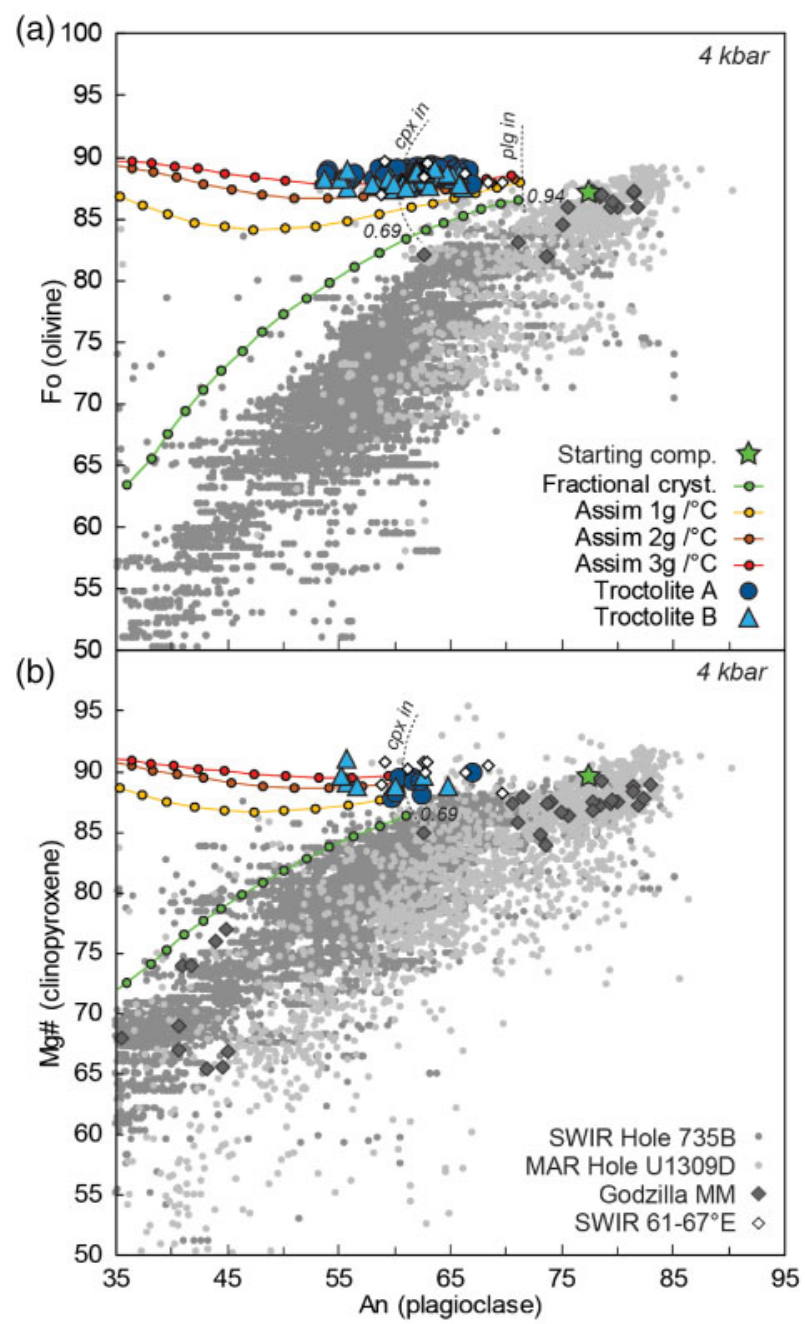

Fig. 16. pMELTs numerical simulations (Ghiorso et al., 2002) of the major element compositions of plagioclase (anorthite content) vs (a) olivine (forsterite content), and (b) clinopyroxene (Mg-number) during fractional crystallization and reactive crystallization of a sodic primitive MORB, after Saccani et al. (2008) (see text for details). Varying assimilation rates of a dunite (100\% olivine) from 1 to $3 \mathrm{~g}^{\circ} \mathrm{C}^{-1}$ of cooling are modelled, and compared with the core compositions of olivine-plagioclase, and clinopyroxene-plagioclase pairs analyzed in Troctolite A and Troctolite B. The green star represents the mineral compositions in equilibrium with the starting melt, and each dot along the crystal line of descent corresponds to a $5^{\circ} \mathrm{C}$ cooling step. The numbers along the fractional crystallization trend represent the remaining melt fraction at the saturation of plagioclase and clinopyroxene. Compositional fields for oceanic gabbroic suites are plotted for comparison: South-West Indian Ridge (SWIR Hole 735B: Dick et al., 2002; SWIR 61-67 E: Paquet et al., 2016); Mid-Atlantic Ridge (MAR; Ross \& Elthon, 1997; Lissenberg \& Dick, 2008; Suhr et al., 2008; Drouin et al., 2009; Miller et al., 2009) and the Godzilla Megamullion (Godzilla MM; Harigane et al., 2011; Sanfilippo et al., 2013).

Troctolite A (from 55 to $97 \%$ modal olivine). The olivine matrix within Troctolite B shows extreme textural variations (Figs 3b-e and 6e), from millimetre-size euhedral (Fig. 7a) to centimetre-size hopper (Fig. 7b) to centimetre- to decimetre-size skeletal and dendritic crystals (Fig. 7c and d) (Rampone et al., 2016). Hopper and dendritic morphologies of olivine have been previously described in the Rum Layered Intrusion (Donaldson, 1974, 1977, 1982; O'Driscoll et al., 2007), in olivine-rich troctolites from the Ligurian ophiolites (Renna et al., 2016) and in crystallization experiments (Donaldson, 1976, 1977; Faure et al., 2003, 2007) resulting from rapid disequilibrium crystallization of an undercooled melt (driven by a difference between the liquidus temperature of the melt and the melt temperature).

Olivine CPO in the granular portion of Troctolite B shows random orientations of the [100] axis, strong concentrations of the [010] axis normal to the foliation, and the [001] axis being the strongest axis concentration within the foliation plane (Fig. 9). In gabbroic intrusions, similar olivine CPOs are observed, correlated with strong orientations of the plagioclase [010] axis normal to the foliation plane (parallel to the [010] axis of olivine) (Fig. 9). Benn \& Allard (1989) and Jousselin et al. (2012) previously described such CPOs of olivine in the Oman lower crustal layered gabbros and interpreted these orientations as the shape-related physical orientation of the crystals during magmatic flow.

Based on the crosscutting relationships between Troctolite B and the host Troctolite A (Figs $2 b$ and $3 a, c$ ), the textural variability of olivine (Figs $3 \mathrm{~b}-\mathrm{e}$ and $6 \mathrm{e}$ ), and the CPO indicative of magmatic flow within the granular part of Troctolite B (Fig. 9), we infer that Troctolite B originated as a magmatic segregation within hot, preexisting Troctolite A during focused percolation of the melt modified after the diffuse reactive percolation forming Troctolite A (see the modelling below). The irregular contacts between the Troctolite $B$ intrusions and the host Troctolite $A$ indicate a brittle-ductile rheological behaviour, thus suggesting a minor temperature difference $\left(<50^{\circ} \mathrm{C}\right)$ between the system and the intruding melt. The rheological evolution from diffuse percolation (forming Troctolite A) to focused percolation (related to a slight decrease in the temperature of the system) allowed higher quantities of melt to segregate and to form a magmatic flow (Fig. 9), leading to the crystallization of Troctolite B.

The mineral major element compositions of olivine, plagioclase and clinopyroxene in Troctolite B are less variable than in Troctolite $A$. The forsterite contents in olivine (Fo $=87.3-89.2$; Figs $10 \mathrm{a}$ and $14 \mathrm{~b}, \mathrm{c}$ ), the Mgnumbers ( $\mathrm{Mg} \#=88 \cdot 2-91$; Figs 11 and $14 \mathrm{a}$, c) and $\mathrm{Cr}_{2} \mathrm{O}_{3}$ contents in clinopyroxene (up to $\mathrm{Cr}_{2} \mathrm{O}_{3}=1.55 \mathrm{wt} \%$; Fig. 11a and c), and the anorthite contents in plagioclase $(A n=55 \cdot 1-66.1 ;$ Fig. 14) are in the same range of composition as previously described in Troctolite $A$. The geochemical model (using pMELTs; Ghiorso et al., 2002) of reactive fractional crystallization developed for the host Troctolite A (Fig. 16) also fits the major element compositions of the Troctolite B mineral pairs, showing constant forsterite contents in olivine and Mg-numbers in clinopyroxene at decreasing anorthite contents in plagioclase (Figs 14b, c and 16). This indicates that the magmatic Troctolite $B$ crystallized from the melt modified after the diffuse reactive percolation originating 

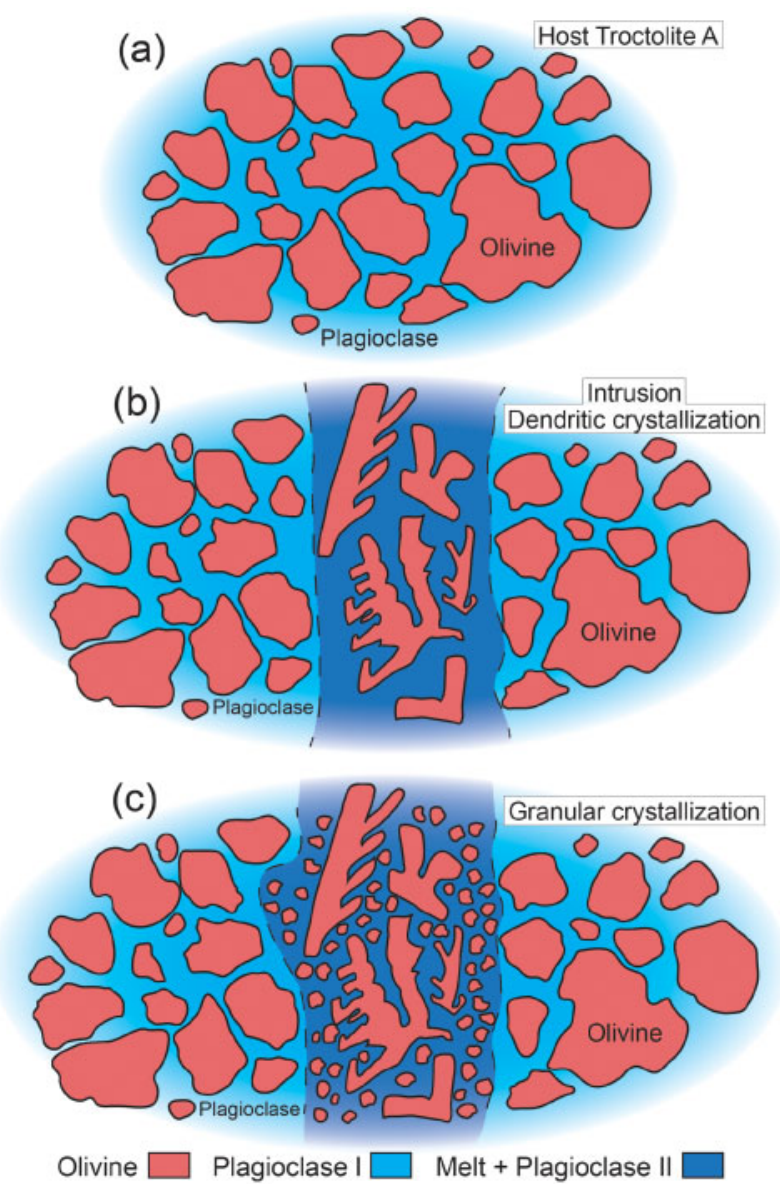

Fig. 17. Representative sketches for the formation of Troctolite B. (a) Initial state, host Troctolite A crystal mush. (b) Prior crystallization of dendritic olivine from the undercooled melt. (c) Equilibrium crystallization of fine-grained granular olivine.

Troctolite A. Table 7 reports the initial melt composition and liquidus temperature of the Pineto primitive MORB melt used in the thermodynamic model of fractional and reactive crystallization (see Discussion), and the modified melt composition and liquidus temperature computed using pMELTs (Ghiorso et al., 2002), after dissolution of 5,10 and $15 \mathrm{~g}$ of olivine (corresponding to a $5^{\circ} \mathrm{C}$ step of cooling for the modelled 1,2 and $3 \mathrm{~g}^{\circ} \mathrm{C}^{-1}$; Fig. 16). It should be noted that the modified compositions reported in Table 7 consider only the dissolution of the olivine matrix during a $5^{\circ} \mathrm{C}$ cooling step, and not the subsequent precipitation of olivine from the melt. This approach allows us to compute the maximum increase in liquidus temperature driven by olivine assimilation (Table 7) in the modified melts, and therefore to assess the maximum degree of undercooling developed prior to olivine reprecipitation. The dissolution of olivine leads to a local increase of the Mg-number of the melt, resulting in an increase of the liquidus temperature of the melt of up to $83^{\circ} \mathrm{C}$ (relative to the liquidus temperature of the initial melt), for the assimilation of $15 \mathrm{~g}$ of olivine during one $5^{\circ} \mathrm{C}$ step of cooling $\left(3 \mathrm{~g}^{\circ} \mathrm{C}^{-1}\right.$ of cooling; Ghiorso et al., 2002; Table 7). Hence, the described process of partial dissolution of the olivine matrix is able to rapidly develop a significant degree of undercooling of the melt, by increasing its liquidus temperature at almost constant melt temperature. We infer that the textural variability of olivine observed within the magmatic Troctolite $B$ is the result of local changes in the degree of undercooling of the segregated melt, as was previously described for the Rum layered intrusion (Donaldson, 1974, 1976, 1977, 1982; O'Driscoll et al., 2007). Crystallization experiments of mafic-ultramafic melts performed over a range of degrees of undercooling and cooling rates (Donaldson et al., 1975; Donaldson, 1976, 1977; Faure et al., 2003, 2007) have highlighted the possible development of hopper and dendritic olivine morphologies at degrees of undercooling as low as $10-20^{\circ} \mathrm{C}$. Olivine dissolution involved in the reactive formation of Troctolite $A$ is therefore a very good candidate to explain the skeletal and dendritic morphologies of magmatic olivine crystallized in Troctolite B.

The lack of significant geochemical variation between the different olivine morphologies (granular, hopper and skeletal) precludes the identification of a clear scenario for their formation sequence. However, slightly more evolved major element compositions of olivine (Fo $=87.5-88$, Fig. 10), plagioclase $(A n=60-62$, Fig. 13) and clinopyroxene ( $\mathrm{Mg} \#=88.7-89.5)$ in the granular part of Troctolite B (MF46A, Table 1) possibly imply later crystallization, after the rapid growth of skeletal dendritic olivines. Moreover, O'Driscoll et al. (2007) previously proposed for the Rum layered intrusion that the absence of initial suspended olivine in the primitive magmatic flow may favour the development of melt undercooling. These arguments point to a model of formation of Troctolite $B$ in which dendritic olivines rapidly formed in the undercooled melt, prior to its evolution and the crystallization of the granular olivines (Fig. 17).

\section{Intrusion of the modified melt-formation of the gabbroic intrusions}

Gabbroic intrusions crosscut both the troctolitic body and the associated impregnated plagioclase Iherzolites and have straight contacts with their host-rocks (Borghini \& Rampone, 2007; Borghini et al., 2007; Rampone et al., 2016). Olivines and plagioclases from the gabbroic intrusions show CPO consistent with the shape-related orientation of the crystals in a magmatic flow (Benn \& Allard, 1989; Jousselin et al., 2012). Major element compositions of the rock-forming minerals (forsterite content of olivine, anorthite content of plagioclase and $\mathrm{Mg}$-number in clinopyroxene) show a positive correlation and an evolution following a fractional crystallization trend, parallel to the compositional trends reported for oceanic gabbroic series at the Mid-Atlantic Ridge (Fig. 14b and c) (Ross \& Elthon, 1997; Lissenberg \& Dick, 2008; Suhr et al., 2008; Drouin et al., 2009; Miller et al., 2009; Ferrando et al., 2018) and the South-West Indian Ridge (Dick et al., 2002). However, although showing similar mineral geochemical trends of 
evolution to the oceanic gabbroic series, their compositions are shifted towards higher forsterite contents in olivine and $\mathrm{Mg}$-numbers in clinopyroxene at a given anorthite content in plagioclase (Fig. 14b and c). The most primitive gabbroic intrusions show mineral major element compositions similar to those in Troctolite B, thus indicating a common parental melt. Accordingly, we infer that the gabbroic intrusions formed by fractional crystallization of the melt modified after the reactive fractional crystallization that formed Troctolites $A$ and $B$ (Fig. 16), at lower temperatures allowing for brittle behaviour and emplacement of the melt in fractures (Borghini et al., 2007; Rampone \& Borghini, 2008).

To test this hypothesis, we performed a geochemical modelling study of fractional crystallization (using pMELTS; Ghiorso et al., 2002) using as a starting melt the output modified melt composition after previous reactive fractional crystallization (Fig. 18; Table 7). As shown in Fig. 18, the fractional crystallization of the modified melt reproduces the chemical covariation arrays observed in the gabbroic intrusions, almost parallel to the trends defined by oceanic gabbroic suites, but shifted towards more Mg-rich mineral compositions of olivine (forsterite content) and clinopyroxene (Mgnumber). This confirms that the parental melt of the gabbroic intrusions corresponds to the melt modified after formation of Troctolites A and B, and that no further melt-rock interaction was involved in the fractional crystallization process.

\section{Constraints on the geodynamic context and melt-rock interaction processes}

Geochronological data for the Erro-Tobbio gabbroic intrusions (Sm-Nd, $178 \pm 5 \mathrm{Ma}$; Rampone et al., 2014), together with gabbroic rocks from the External Liguride units (170-179 Ma Northern Apennines; Tribuzio et al., 2004), yield the oldest ages available for the gabbroic crust of the Ligurian Tethys ocean. These ages are older than the age of continental break-up and onset of oceanization of the Ligurian Tethys (164-166 Ma; Manatschal \& Müntener, 2009). Also, they indicate an $\sim 10$ Myr time gap between the early emplacement of the Erro-Tobbio and External Liguride gabbros, and the main magmatic activity of the Ligurian Tethys (155$165 \mathrm{Ma}$; Rampone et al., 2014, and references therein). Accordingly, the Erro-Tobbio gabbroic intrusions have been interpreted as evidence of early magmatism in thinned lithospheric mantle exhumed in an ocean-continent transition setting during the onset of Jurassic lithospheric extension (Fig. 19a; Manatschal \& Müntener, 2009; Rampone et al., 2014). The scarcity of gabbroic and basaltic bodies in the Alpine-Apennine ophiolites (e.g. Marroni et al., 1998; Tribuzio et al., 2000, 2004; Montanini et al., 2008; Saccani et al., 2008), and the Na-rich composition of the basaltic parental melts (Fig. 14c; Saccani et al., 2008; see Discussion) are consistent with low-degree melting of the upwelling mantle in a slow- to ultraslow-spreading environment (Klein \&

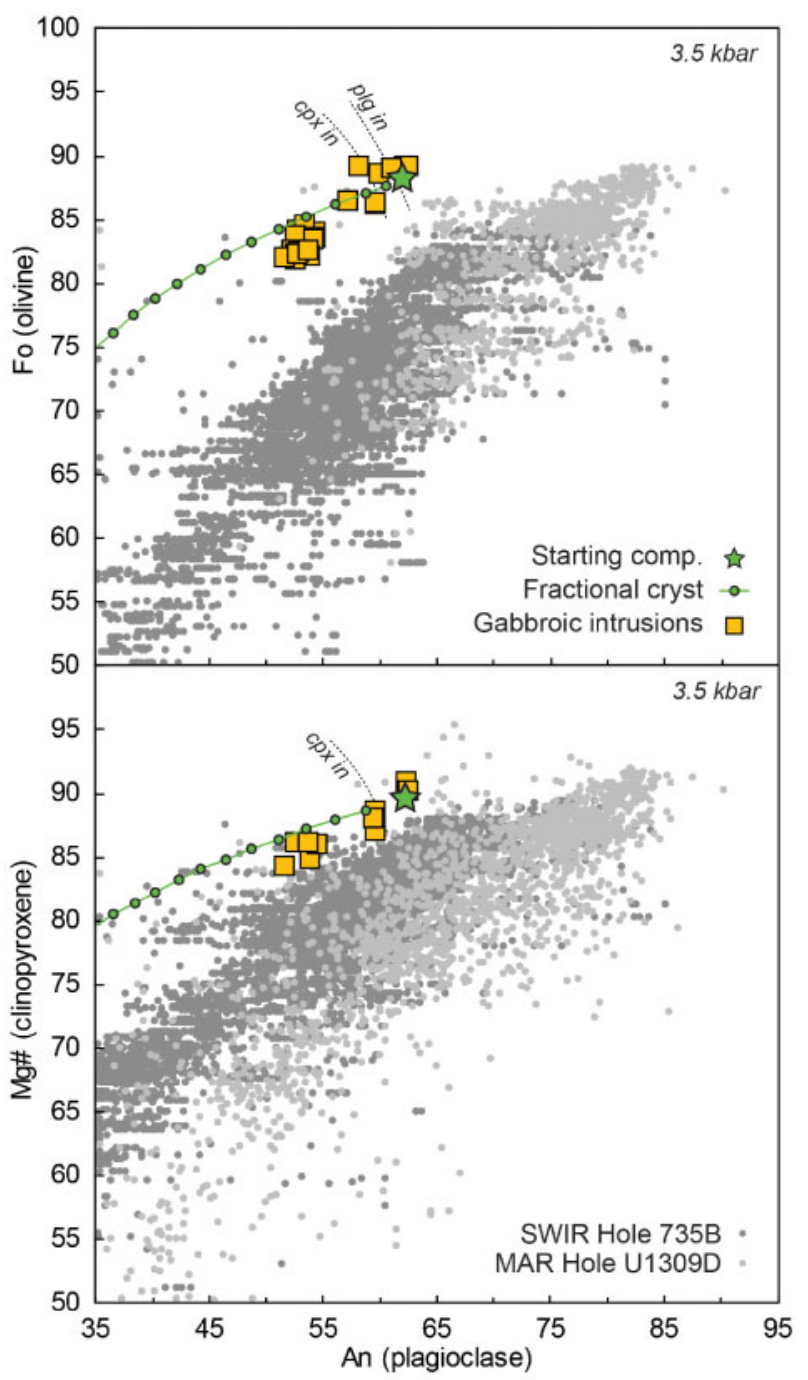

Fig. 18. pMELTs numerical modelling (Ghiorso et al., 2002) of the major element compositions of olivine (forsterite content), plagioclase (anorthite content) and clinopyroxene (Mg-number) during fractional crystallization of the melt modified after reactive equilibrium crystallization and formation of Troctolite $A$ and Troctolite $B$, compared with the major element core compositions of olivine-plagioclase and clinopyroxene-plagioclase pairs analyzed from the Erro-Tobbio gabbroic intrusions. The green star represents the mineral compositions in equilibrium with the starting melt, and each dot along the crystal line of descent corresponds to a $5^{\circ} \mathrm{C}$ cooling step. Compositional fields of oceanic gabbroic suites are as in Fig. 16.

Langmuir, 1987; Montanini et al., 2008; Saccani et al., 2008; Renna et al., 2018; Fig. 19a).

Our structural data, showing the partial preservation of the protolith axial [100] olivine CPO during replacive formation of Troctolite A (Fig. 8), point to a percolation process occurring at variable instantaneous melt/rock ratios, in an overall low melt supply regime (Fig. 15; see Discussion). Also, our thermodynamic models show that extensive dissolution-precipitation reactions are needed during the multi-stage formation of Troctolite $A$ and Troctolite B to explain their peculiar compositional trends (Figs 16 and 19b; see Discussion). As demonstrated by several mass-balance and AFC models 

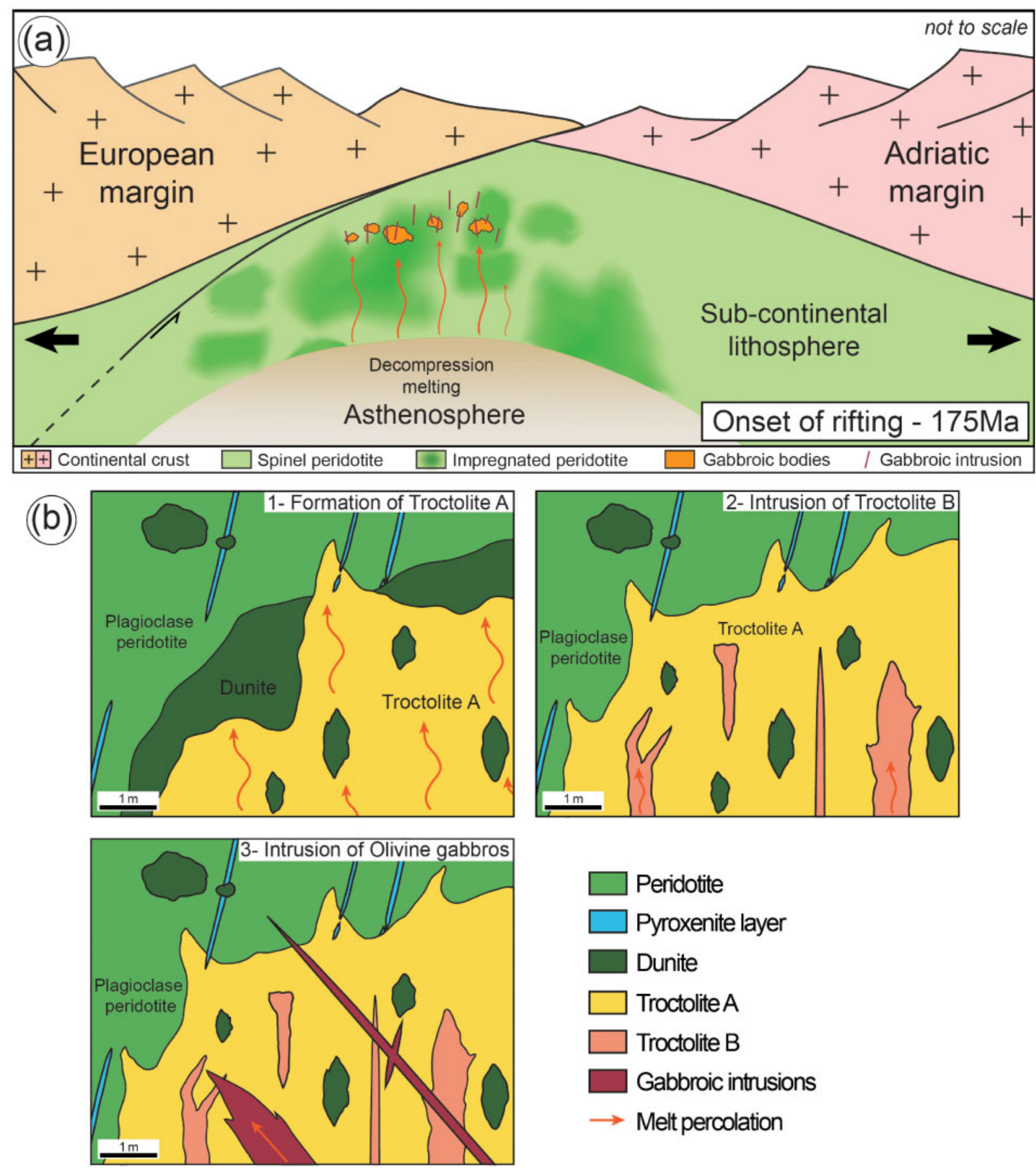

Fig. 19. Interpretative sketches of the geological context and evolution of the peridotitic and troctolitic body. (a) Geological context of the formation of the Erro-Tobbio troctolitic body at $175 \mathrm{Ma}$, during the onset of the Ligurian Tethys basin rifting. (b) Representative replacive formation of Troctolite A from a dunitic protolith, intrusion of Troctolite B during focused melt percolation and intrusion of gabbroic rocks in fractures.

(Lissenberg \& Dick, 2008; Sanfilippo et al., 2015b; Paquet et al., 2016; Rampone et al., 2016), modifications of the melt composition during melt-rock interaction are possible only at low melt supply conditions. Corerim composition profiles in interstitial phases from Troctolite A (plagioclase and clinopyroxene, Fig. 12a-h) show decreasing $\mathrm{Cr}_{2} \mathrm{O}_{3}$ and $\mathrm{Al}_{2} \mathrm{O}_{3}$, and increasing $\mathrm{TiO}_{2}$ concentrations in clinopyroxene towards the rim
( $<200 \mu \mathrm{m}$ from the contact with olivine), and decreasing anorthite content and $\mathrm{CaO}$ and $\mathrm{Al}_{2} \mathrm{O}_{3}$ concentrations towards the plagioclase rim. These core-rim chemical zonations in interstitial clinopyroxene and plagioclase suggest an in situ evolution of the melt composition during reactive crystallization at decreasing melt mass (Borghini \& Rampone, 2007; Borghini et al., 2007; Rampone \& Borghini, 2008). This indicates that the 
process forming the replacive Troctolite A is not characterized by constant replenishment and efficient extraction of the melt (Fig. 19b), but rather by sparse melt injections, the chemical compositions of which were dominated by the dissolution-precipitation processes.

Mineral reactive compositional trends (constant Mg\# of olivine and clinopyroxene at variable An content in plagioclase), similar to those observed in the ErroTobbio troctolitic body, have been documented in olivine-rich troctolites from slow-spreading oceanic environments at the easternmost South-West Indian Ridge (Fig. 16; Paquet et al., 2016) and at the Godzilla Megamullion (Fig. 16; Sanfilippo et al., 2016b). Both these settings are characterized by scarce basaltic and gabbroic intrusions in kilometres of exhumed mantle peridotites. In these troctolites, peculiar compositional trends in minerals have been interpreted as the result of extensive melt-rock interaction processes involving low magma supplies and melt/rock ratios (Paquet et al., 2016; Sanfilippo et al., 2016b).

Replacive olivine-rich troctolites have also been described from the Atlantis Massif [Integrated Ocean Drilling Program (IODP) Hole U1309D; Blackman et al., 2006; Suhr et al., 2008; Drouin et al., 2009, 2010; Ferrando et al., 2018], associated with a $1415 \mathrm{~m}$ long crustal section (>90\% gabbroic rocks; Blackman et al., 2006). Interestingly, the mineral compositions of these olivine-rich troctolites and associated gabbroic crust follow a trend of fractional crystallization at $\sim 2 \mathrm{kbar}$ (Miller et al., 2009). This indicates that the global composition of the percolating MORB melt was not modified during the melt-rock interaction processes and formation of replacive olivine-rich troctolites (Ferrando et al., 2018). Consistently, structural data for the olivine CPO within the olivine-rich troctolites from the Atlantis Massif suggest high melt supply and melt/rock ratios involved in the melt percolation and dissolution-precipitation reactions (Drouin et al., 2010; Ferrando et al., 2018). This further confirms that low melt/rock ratios are necessary to drive a significant modification of the melt composition during melt-rock interaction processes.

The context of formation of the Erro-Tobbio troctolitic body and associated gabbroic intrusions is therefore representative of a slow- to ultraslow-spreading system characterized by very low melt supply, therefore allowing the percolating melt composition to be controlled and buffered by the melt-rock interaction processes.

\section{SUMMARY AND CONCLUSIONS}

In the studied area, the Erro-Tobbio peridotites, troctolites and gabbroic intrusions record a multi-stage structural and geochemical evolution involving extensive dissolution-precipitation reactions. This can be summarized as follows.

(1) The formation of the replacive Troctolite $A$ is related to diffuse reactive melt percolation in a preexisting dunitic matrix (Fig. 19b). Mineral compositions in Troctolite $A$ and thermodynamic models indicate a melt-rock interaction-dominated process (Fig. 16), which involves olivine dissolution and crystallization of plagioclase and minor clinopyroxene.

(2) Subsequently, the focusing of melts modified after reactive percolation leads to the formation of pseudo-tabular Troctolite B magmatic bodies (Fig. 19b). High degrees of undercooling in the modified melt resulted in hopper to dendritic olivine morphologies during crystallization of Troctolite B (Fig. 17).

(3) The late gabbroic dykes, crosscutting the association between the impregnated plagioclase peridotites and Troctolites $A$ and $B$, represent the product of fractional crystallization of the same modified melts (Fig. 19b).

The evolution from diffuse reactive percolation to focused reactive percolation, followed by intrusion and fractional crystallization of the gabbroic intrusions, is driven by the decreasing temperature of the exhuming system (Fig. 19a), controlling the rheology of the hostrock and the ability of the melt to segregate into magmatic intrusions. The geochemical similarities observed between Troctolite $B$ and the most primitive gabbroic intrusions indicate a common modified parental melt, which allows us to link the focused percolation and intrusion events. Thus, the multi-stage formation of the troctolitic body and associated gabbroic intrusions (Fig. 19b) are related to a single thermal evolution of the ultramafic body, during the onset of opening of the Ligurian Tethys (Fig. 19a).

This study provides field-controlled constraints on the structural and geochemical modifications induced by melt-rock interaction processes, as a function of the involved melt/rock ratio. At low melt supply and melt/ rock ratios, the structure of the protolith is preserved during reactive crystallization, and the melt composition can be easily controlled by the continuing dissolution-precipitation reactions. This leads to the observed buffering of the melt composition towards high Mg-numbers in the troctolitic body. In contrast, melt percolation involving high melt supply and melt/ rock ratios leads to the loss of cohesion of the solid matrix and pre-existing structure. In such circumstances, the global melt composition cannot be modified during melt-rock interactions and the crystallized minerals follow a fractional crystallization trend, as documented at the Atlantis Massif.

\section{ACKNOWLEDGEMENTS}

We would like to thank Professor Joerg Hermann, Dr Alessio Sanfilippo and an anonymous reviewer for their constructive comments, which have improved the quality of the paper. We also thank Paolo Campanella and Alessandra Gavoglio, Christophe Nevado and Doriane Delmas for realization of the thin section and highquality polishing, as well as Fabrice Barou for assistance with the EBSD analyses, Andrea Risplendente for assistance with the EPMA, Marco Scarsi and Nicola 
Campomenosi for assistance with fieldwork, and Giulio Borghini for stimulating discussions.

\section{FUNDING}

This project has been supported by the People Programme (Marie Curie Actions) of the European Union's Seventh Framework Programme FP7/20072013/ under REA-Grant Agreement No. 608001, 'ABYSS', and by the Italian Ministry of Education, University and Research (MIUR) [PRIN-2015C5LN35] 'Melt-rock reaction and melt migration in the MORB mantle through combined natural and experimental studies'.

\section{SUPPLEMENTARY DATA}

Supplementary data are available at Journal of Petrology online.

\section{REFERENCES}

Basch, V. (2018). Melt-rock interactions in the oceanic lithosphere: microstructural and petro-geochemical constraints from ophiolites. PhD thesis, Università degli Studi di Genova.

Basch, V., Rampone, E., Crispini, L., Ferrando, C., Ildefonse, B. \& Godard, M. (2018). From mantle peridotites to hybrid troctolites: textural and chemical evolution during melt-rock interaction history (Mt. Maggiore, Corsica, France). Lithos 323, 4-23.

Bender, J. F., Hodges, F. N. \& Bence, A. E. (1978). Petrogenesis of basalts from the project FAMOUS area: experimental study from 0 to 15 kbars. Earth and Planetary Science Letters 41, 277-302.

Ben Ismail, W. \& Mainprice, D. (1998). An olivine fabric database: an overview of upper mantle fabrics and seismic anisotropy. Tectonophysics 296, 145-157.

Benn, K. \& Allard, B. (1989). Preferred mineral orientations related to magmatic flow in ophiolite layered gabbros. Journal of Petrology 30, 925-946.

Bezzi, A. \& Piccardo, G. B. (1971). Structural features of the Ligurian ophiolites: petrologic evidence for the 'oceanic' floor of the Northern Apennines geosyncline: a contribution to the problem of the alpine-type gabbro-peridotite associations. Memorie della Società Geologica Italiana 10, 53-63.

Blackman, D. K., Ildefonse, B., John, B. E., Ohara, Y., Miller, D. J., MacLeod, C. J. \& Expedition 304/305 Scientists (2006). Expedition 304/305 summary. In: Blackman, D. K., Ildefonse, B., John, B. E., Ohara,Y., Miller, D. J., MacLeod, C. J. \& the Expedition 304/305 Scientists (eds) Proceedings of the Integrated Ocean Drilling Program, Vol. 304/305. College Station, TX: Integrated Ocean Drilling Program, p. 60.

Borghini, G. \& Rampone, E. (2007). Postcumulus processes in oceanic-type olivine-rich cumulates: the role of trapped melt crystallization versus melt-rock interaction. Contributions to Mineralogy and Petrology 154, 619-633.

Borghini, G., Rampone, E., Crispini, L., De Ferrari, R. \& Godard, M. (2007). Origin and emplacement of ultramafic-mafic intrusions in the Erro-Tobbio mantle peridotite (Ligurian Alps, Italy). Lithos 94, 210-229.

Borghini, G., Francomme, J. E. \& Fumagalli, P. (2018). Melt-dunite interactions at 0.5 and $0.7 \mathrm{GPa}$ : experimental constraints on the origin of olivine-rich troctolites. Lithos 323, 44-57.

Borsi, L., Scharer, U., Gaggero, L. \& Crispini, L. (1996). Age, origin and geodynamic significance of plagiogranites in Iherzolites and gabbros of the Piedmont-Ligurian ocean basin. Earth and Planetary Science Letters 140, 227-241.

Boudier, F. \& Nicolas, A. (1995). Nature of the transition zone in the Oman ophiolite. Journal of Petrology 36, 777-796.

Bunge, H. J. (1982). Texture Analysis in Material Sciences. London: Butterworths.

Capponi, G., Crispini, L., Silvestri, R. \& Vigo, E. (1999). The role of Early Miocene thrust tectonics in the structural arrangement of the Voltri Group (Ligurian Alps, Italy): evidence of Bandita area. Ofioliti 24, 13-19.

Ceuleneer, G. \& Rabinowicz, M. (1992). Mantle flow and melt migration beneath oceanic ridges: models derived from observation in ophiolites, in mantle flow and melt generation at mid-ocean ridges. In: Morgan, J. P., Blackman, D. B. and Sinton, J. M. (eds) Mantle Flow and Melt Generation at Mid-Ocean Ridges. American Geophysical Union, Geophysical Monograph Series, 71, 123-154.

Chiesa, S., Cortesogno, L., Forcella, F., Galli, M., Messiga, B., Pasquarè, G., Pedemonte, G. M., Piccardo, G. B. \& Rossi, P. M. (1975). Assetto strutturale ed interpretazione geodinamica del Gruppo di Voltri. Bolletino della Società Geologica Italiana 94, 555-581.

Collier, M. L. \& Kelemen, P. B. (2010). The case for reactive crystallization at mid-ocean ridges. Journal of Petrology 51, 1913-1940.

Coumans, J. P., Stix, J., Clague, D. A., Minarik, W. G. \& Layne, G. D. (2016). Melt-rock interaction near the Moho: evidence from crystal cargo in lavas from near-ridge seamounts. Geochimica et Cosmochimica Acta 191, 139-164.

Dick, H. J. B., Ozawa, K., Meyer, P. S., Niu, Y., Robinson, P. T., Constantin, M., Hebert, R., Maeda, J., Natland, J. H., Hirth, J. G. \& Mackie, S. M. (2002). Primary silicate mineral chemistry of a $1.5-\mathrm{km}$ section of very slow spreading lower ocean crust: ODP hole 735B, southwest Indian ridge. In: Natland, J. H., Dick, H. J. B., Miller, D. J. and Von Herzen, R. P. (eds) Proceedings of the Ocean Drilling Program, Scientific Results, Vol. 176. College Station, TX: Ocean Drilling Program, pp. 1-61.

Dick, H. J. B., Tivey, M. A. \& Tucholke, B. E. (2008). Plutonic foundation of a slow-spreading ridge segment: oceanic core complex at Kane Megamullion, $23^{\circ} 30^{\prime} \mathrm{N}, 45^{\circ} 20^{\prime} \mathrm{W}$. Geochemistry, Geophysics, Geosystems 9, 005014.

Dick, H. J. B., Lissenberg, C. J. \& Warren, J. M. (2010). Mantle melting, melt transport, and delivery beneath a slow-spreading ridge: the paleo-MAR from $23^{\circ} 15^{\prime} \mathrm{N}$ to $23^{\circ} 45^{\prime} \mathrm{N}$. Journal of Petrology 51, 425-467.

Dijkstra, A. H., Drury, M. R. \& Frijhoff, R. M. (2002). Microstructures and lattice fabrics in the Hilti mantle section (Oman Ophiolite): evidence for shear localization and melt weakening in the crust-mantle transition zone? Journal of Geophysical Research 107, 2270.

Dijkstra, A. H., Barth, M. G., Drury, M. R., Mason, P. R. D. \& Vissers, R. L. M. (2003). Diffuse porous melt flow and melt-rock reaction in the mantle lithosphere at a slow-spreading ridge: a structural petrology and LA-ICP-MS study of the Othris Peridotite Massif (Greece). Geochemistry, Geophysics, Geosystems 4, 8613.

Dohmen, R. \& Chakraborty, S. (2007). Fe-Mg diffusion in olivine II: point defect chemistry, change of diffusion mechanisms and a model for calculation of diffusion coefficients in natural olivine. Physics and Chemistry of Minerals 34, 409-430.

Donaldson, C. H. (1974). Olivine crystal types in harrisitic rocks of the Rhum pluton and in Archean spinifex rocks. Geological Society of American Bulletin 85, 1721-1726. 
Donaldson, C. H. (1976). An experimental investigation of olivine morphology. Contributions to Mineralogy and Petrology 57, 187-213.

Donaldson, C. H. (1977). Laboratory duplication of comb layering in the Rhum pluton. Mineralogical Magazine 41, 323-336.

Donaldson, C. H. (1982). Origin of some of the Rhum harrisite by segregation of intercumulus liquid. Mineralogical Magazine 45, 201-209.

Donaldson, C. H., Williams, R. J. \& Lofgren, G. E. (1975). A sample holding technique for study of crystal growth in silicate melts. American Mineralogist 60, 324-326.

Drouin, M., Godard, M., Ildefonse, B., Bruguier, O. \& Garrido, C. (2009). Geochemical and petrographic evidence for magmatic impregnation in the oceanic lithosphere at Atlantis Massif, Mid-Atlantic Ridge (IODP Hole U1309D, 30 N). Chemical Geology 264, 71-88.

Drouin, M., Ildefonse, B. \& Godard, M. (2010). A microstructural imprint of melt impregnation in slow spreading lithosphere: olivine-rich troctolites from the Atlantis Massif, Mid-Atlantic Ridge, $30^{\circ} \mathrm{N}$, IODP Hole U1309D. Geochemistry, Geophysics, Geosystems 11, 006003.

Dygert, N., Liang, Y. \& Kelemen, P. B. (2016). Formation of plagioclase Iherzolite and associated dunite-harzburgite-Iherzolite sequences by multiple episodes of melt percolation and melt rock reaction: an example from the Trinity ophiolite, California, USA. Journal of Petrology 57, 815-838.

Ernst, W. G. \& Piccardo, G. B. (1979). Petrogenesis of some Ligurian peridotites: I. Mineral and bulk rock chemistry. Geochimica et Cosmochimica Acta 43, 219-237.

Faure, F., Trolliard, G., Nicollet, C. \& Montel, J. M. (2003). A developmental model of olivine morphology as a function of the cooling rate and the degree of undercooling. Contributions to Mineralogy and Petrology 145, 251-263.

Faure, F., Schiano, P., Trolliard, G., Nicollet, C. \& Soulestin, B. (2007). Textural evolution of polyhedral olivine experiencing rapid cooling rates. Contributions to Mineralogy and Petrology 153, 405-416.

Ferrando, C., Godard, M., Ildefonse, B. \& Rampone, E. (2018). Melt transport and mantle assimilation at Atlantis Massif (IODP Site U1309): constraints from geochemical modelling. Lithos 323, 24-43.

Francomme, J. E. (2018). Melt-rock interaction at the mantlecrust transition zone in the oceanic spreading lithosphere: an experimental study. $\mathrm{PhD}$ thesis, Università degli Studi di Milano.

Garrido, C. J. \& Bodinier, J.-L. (1999). Diversity of mafic rocks in the Ronda peridotite: evidence for pervasive melt-rock reaction during heating of subcontinental lithosphere by upwelling asthenosphere. Journal of Petrology 40, 729-754.

Ghiorso, M. S., Hirschmann, M., Reiners, P. W. \& Kress, V. C. I. (2002). The pMELTS: a revision of MELTS aimed at improving calculation of phase relations and major element partitioning involved in partial melting of the mantle at pressures up to $3 \mathrm{GPa}$. Geochemistry, Geophysics, Geosystems, 3, 36.

Godard, M., Bodinier, J.-L. \& Vasseur, G. (1995). Effects of mineralogical reactions on trace element redistributions in mantle rocks during percolation processes: a chromatographic approach. Earth and Planetary Science Letters 133, 449-461.

Harigane, Y., Michibayashi, K. \& Ohara, Y. (2011). Deformation and hydrothermal metamorphism of gabbroic rocks within the Godzilla Megamullion, Parece Vela Basin, Philippine Sea. Lithos 124, 185-199.

Hébert, R., Serri, G. \& Hekinian, R. (1989). Mineral chemistry of ultramafic tectonites and ultramafic to gabbroic cumulates from the major oceanic basins and Northern Apennines ophiolites (Italy)—a comparison. Chemical Geology 77, 183-207.

Higgie, K. \& Tommasi, A. (2012). Feedbacks between deformation and melt distribution in the crust-mantle transition zone of the Oman ophiolite. Earth and Planetary Science Letters 359-360, 61-72.

Higgie, K. \& Tommasi, A. (2014). Deformation in a partially molten mantle: constraints from plagioclase Iherzolites from Lanzo, western Alps. Tectonophysics 615-616, 167-181.

Hoogerduijn-Strating, E. H., Piccardo, G. B., Rampone, E., Scambelluri, M. \& Vissers, R. L. (1990). The structure and petrology of the Erro-Tobbio peridotite, Voltri massif, Ligurian Alps: guidebook for a two-day-excursion with emphasis on processes in the upper mantle. Ofioliti 15, 119-184.

Hoogerduijn-Strating, E. H., Rampone, E., Piccardo, G. B., Drury, M. R. \& Vissers, R. L. M. (1993). Subsolidus emplacement of mantle peridotites during incipient oceanic rifting and opening of the Mesozoic Tethys (Voltri Massif, NW Italy). Journal of Petrology 34, 901-927.

Husen, A., Renat, R. A. \& Holtz, F. (2016). The effect of $\mathrm{H}_{2} \mathrm{O}$ and pressure on multiple saturation and liquid lines of descent in basalt from the Shatsky Rise. Journal of Petrology 57 309-344.

Jousselin, D., Nicolas, A. \& Boudier, F. (1998). Detailed mapping of a mantle diapir below a paleo-spreading center in the Oman ophiolite. Journal of Geophysical Research: Solid Earth 103, 18153-18170.

Jousselin, D., Morales, L. F. G., Nicolle, M. \& Stephant, A. (2012). Gabbro layering induced by simple shear in the Oman ophiolite Moho transition zone. Earth and Planetary Science Letters 331-332, 55-66.

Karato, S-I., Jung, H., Katayama, I. \& Skemer, P. (2008). Geodynamic significance of seismic anisotropy of the upper mantle: new insights from laboratory studies. Annual Review of Earth and Planetary Sciences 36, 59-93.

Kelemen, P. B., Hitehead, J. A., Aharonov, E. \& Jordahl, K. A. (1995a). Experiments on flow focusing in soluble porous media, with applications to melt extraction from the mantle. Journal of Geophysical Research: Solid Earth 100, 475-496.

Kelemen, P. B., Shimizu, N. \& Salters, V. J. M. (1995b). Extraction of mid-ocean-ridge basalt from the upwelling mantle by focused flow of melt in dunite channels. Nature 375, 747-753.

Kelemen, P. B., Braun, M. \& Hirth, G. (2000). Spatial distribution of melt conduits in the mantle beneath oceanic spreading ridges: observations from the Ingalls and Oman ophiolites. Geochemistry, Geophysics, Geosystems 1, 1999GC000012.

Kelemen, P. B., Kikawa, E., Miller, D. J. \& Shipboard Scientific Party (2007). Leg 209 summary: processes in a 20-km thick conductive boundary layer beneath the Mid-Atlantic Ridge, $14^{\circ}-16^{\circ}$ N. In: Kelemen, P. B., Kikawa, E. and Miller, D. J. (eds) Proceedings of the Ocean Drilling Project, Scientific Results, Vol. 209. College Station, TX: Ocean Drilling Program, pp. 1-33.

Klein, E. M. \& Langmuir, C. H. (1987). Global correlations of ocean ridge basalt chemistry with axial depth and crustal thickness. Journal of Geophysical Research 92, 8089-8115.

Lambart, S., Laporte, D. \& Schiano, P. (2009). An experimental study of focused magma transport and basalt-peridotite interactions beneath mid-ocean ridges: implications for the generation of primitive MORB compositions. Contributions to Mineralogy and Petrology 157, 429-451.

Laubier, M., Grove, T. L. \& Langmuir, C. H. (2014). Trace element mineral/melt partitioning for basaltic and basaltic andesitic melts: an experimental and laser ICP-MS study with 
application to the oxidation state of mantle source regions. Earth and Planetary Science Letters 392, 265-278.

Le Roux, V., Tommasi, A. \& Vauchez, A. (2008). Feedback between melt percolation and deformation in an exhumed lithosphere-asthenosphere boundary. Earth and Planetary Science Letters 274, 401-413.

Liang, Y. (2003). Kinetics of crystal-melt reaction in partially molten silicates: 1. Grain scale processes. Geochemistry, Geophysics, Geosystems 4, doi:10.1029/2002GC000375.

Liang, Y., Schiemenz, A., Hesse, M. A. \& Parmentier, E. M. (2011). Waves, channels, and the preservation of chemical heterogeneities during melt migration in the mantle. Geophysical Research Letters 38, L20308.

Lissenberg, C. J. \& Dick, H. J. B. (2008). Melt-rock reaction in the lower oceanic crust and its implications for the genesis of mid-ocean ridge basalt. Earth and Planetary Science Letters 271, 311-325.

Lissenberg, C. J. \& MacLeod, C. J. (2016). A reactive porous flow control on mid-ocean ridge magmatic evolution. Journal of Petrology 57, 2195-2220.

Lissenberg, C. J., MacLeod, C. J., Howard, K. A. \& Godard, M. (2013). Pervasive reactive melt migration through fast-spreading lower oceanic crust (Hess Deep, equatorial Pacific Ocean). Earth and Planetary Science Letters 361, 436-447.

Mainprice, D., Bachmann, F., Hielscher, R. \& Schaeben, H. (2014). Descriptive tools for the analysis of texture projects with large datasets using MTEX: strength, symmetry and components. Geological Society of London, Special Publications 409.

Manatschal, G. \& Müntener, O. (2009). A type sequence across an ancient magma-poor ocean-continent transition: the example of the western Alpine Tethys ophiolites. Tectonophysics 73, 4-19.

Marroni, M., Molli, G., Montanini, A. \& Tribuzio, R. (1998). The association of continental crust rocks with ophiolites in the Northern Apennines (Italy): implications for the continent-ocean transition in the Western Tethys. Tectonophysics 292, 43-66.

Miller, D. J., Abratis, M., Christie, D., Drouin, M., Godard, M., Ildefonse, B., Maeda, J., Weinsteiger, A., Yamasaki, T., Suzuki, Y., Niino, A., Sato, Y. \& Takeda, F. (2009). Data report: microprobe analyses of primary mineral phases from site U1309, Atlantis Massif, IODP Expedition 304/305. In: Blackman, D. K., Ildefonse, B., John, B. E., Ohara, Y., Miller, D. J., MacLeod, C. J. \& the Expedition 304/305 Scientists (eds) Proceedings of the International Ocean Drilling Program, Vol. 304/305. College Station, TX: Integrated Ocean Drilling Program, p. 4.

Montanini, A., Tribuzio, R. \& Vernia, L. (2008). Petrogenesis of basalts and gabbros from an ancient continent-ocean transition (External Ligurides ophiolites, Northern Italy). Lithos 101, 453-479.

Morgan, Z. \& Liang, Y. (2005). An experimental study of the kinetics of Iherzolite reactive dissolution with applications to melt channel formation. Contributions to Mineralogy and Petrology 150, 369-385.

Müntener, O., Pettke, T., Desmurs, L., Meier, M. \& Schaltegger, R. (2004). Refertilization of mantle peridotite in embryonic ocean basins: trace element and $\mathrm{Nd}$ isotopic evidence and implications for crust-mantle relationships. Earth and Planetary Science Letters 221, 293-308.

Müntener, O. \& Piccardo, G. B. (2003). Melt migration in ophiolitic peridotites: the message from Alpine-Apennine peridotites and implications for embryonic ocean basins. In: Dilek, Y. and Robinson, P. T. (eds) Ophiolites in Earth History.
Geological Society, London, Special Publications 218, 69-89.

O'Driscoll, B., Donaldson, C. H., Troll, V. R., Jerram, D. A. \& Emeleus, C. H. (2007). An origin for harrisitic and granular olivine in the Rum layered suite, NW Scotland: a crystal size distribution study. Journal of Petrology 48, 253-270.

Ottonello, G., Piccardo, G. B. \& Ernst, W. G. (1979). Petrogenesis of some Ligurian peridotites-II. Rare earth element chemistry. Geochimica et Cosmochimica Acta 43, 1273-1284.

Paquet, M., Cannat, M., Brunelli, D., Hamelin, C. \& Humler, E. (2016). Effect of melt/mantle interactions on MORB chemistry at the easternmost Southwest Indian Ridge $\left(61^{\circ}-67^{\circ} \mathrm{E}\right)$. Geochemistry, Geophysics, Geosystems 17, 4605-4640.

Piccardo, G. B. \& Guarnieri, L. (2010). Alpine peridotites from the Ligurian Tethys: an updated critical review. International Geological Review52, 1138-1159.

Piccardo, G. B. \& Vissers, R. L. M. (2007). The pre-oceanic evolution of the Erro-Tobbio peridotite (Voltri Massif, Ligurian Alps, Italy). Journal of Geodynamics 43, 417-449.

Piccardo, G. B., Rampone, E. \& Vannucci, R. (1990). Upper mantle evolution during continental rifting and ocean formation: evidence from peridotites bodies of the Western Alpine-Northern Apennine system. Mémoires de la Société Géologique de France 156, 323-333.

Piccardo, G. B., Rampone, E. \& Vannucci, R. (1992). Ligurian peridotites and ophiolites: from rift to ocean formation in the Jurassic Ligure-Piemontese basin. Acta Vulcanologica 2, 313-325.

Piccardo, G. B., Müntener, O., Zanetti, A. \& Pettke, T. (2004). Ophiolite peridotites of the Alpine-Apennine system: mantle processes and geodynamic relevance. International Geological Review 40, 1119-1159.

Piccardo, G. B., Zanetti, A. \& Müntener, O. (2007). Melt/peridotite interaction in the Southern Lanzo peridotite: field, textural and geochemical evidence. Lithos 94, 181-209.

Pirard, C., Hermann, J., St O'Neill, H. C. (2013). Petrology and geochemistry of the crust-mantle boundary in a nascent arc, Massif du Sud ophiolite, New Caledonia, SW Pacific. Journal of Petrology54, 1759-1792.

Quick, J. E. (1981). Petrology and petrogenesis of the Trinity peridotite, an upper mantle diapir in the eastern Klamath mountains, northern California. Journal of Geophysical Research 86, 11837-11863.

Quick, J. E. (1982). The origin and significance of large, tabular dunite bodies in the Trinity peridotite, Northern California. Contributions to Mineralogy and Petrology 78, 413-422.

Rampone, E. \& Borghini, G. (2008). Melt migration and intrusion in the Erro-Tobbio peridotites (Ligurian Alps, Italy): insights on magmatic processes in extending lithospheric mantle. European Journal of Mineralogy 20, 573-585.

Rampone, E. \& Piccardo, G. B. (2000). The ophiolite-oceanic lithosphere analogue: new insights from the northern Apennine (Italy). In: Dilek, J., Moores, E., Elthon, D. and Nicolas, A. (eds) Ophiolites and Oceanic Crust: New Insights from Field Studies and Ocean Drilling Program. Geological Society of America, Special Papers 349, 21-34.

Rampone, E., Piccardo, G. B., Vannucci, R., Bottazzi, P. \& Ottolini, L. (1993). Subsolidus reactions monitored by trace element partitioning: the spinel- to plagioclase-facies transition in mantle peridotites. Contributions to Mineralogy and Petrology 115, 1-17.

Rampone, E., Piccardo, G. B., Vannucci, R. \& Bottazzi, P. (1997). Chemistry and origin of trapped melts in ophiolitic peridotites. Geochimica et Cosmochimica Acta 61, 4557-4569. 
Rampone, E., Hofmann, A. W. \& Raczek, I. (1998). Isotopic contrasts within the Internal Liguride ophiolite (N-Italy): the lack of genetic mantle-crust link. Earth and Planetary Science Letters 163, 175-189.

Rampone, E., Romairone, A. \& Hofmann, A. W. (2004). Contrasting bulk and mineral chemistry in depleted peridotites: evidence for reactive porous flow. Earth and Planetary Science Letters 218, 491-506.

Rampone, E., Romairone, A., Abouchami, W., Piccardo, G. B. \& Hofmann, A. W. (2005). Chronology, petrology and isotope geochemistry of the Erro-Tobbio peridotites (Ligurian Alps, Italy): records of late Paleozoic lithospheric extension. Journal of Petrology 46, 799-827.

Rampone, E., Piccardo, G. B. \& Hofmann, A. W. (2008). Multi-stage melt-rock interaction in the Mt. Maggiore (Corsica, France) ophiolitic peridotites: microstructural and geochemical evidence. Contributions to Mineralogy and Petrology 156, 453-475.

Rampone, E., Borghini, G., Romairone, A., Abouchami, W., Class, C. \& Goldstein, S. L. (2014). Sm-Nd geochronology of the Erro-Tobbio gabbros (Ligurian Alps, Italy): insights into the evolution of the Alpine Tethys. Lithos 205, 236-246.

Rampone, E., Borghini, G., Godard, M., Ildefonse, B., Crispini, L. \& Fumagalli, P. (2016). Melt/rock reaction at oceanic peridotite/gabbro transition as revealed by trace element chemistry of olivine. Geochimica et Cosmochimica Acta 190, 309-331.

Rampone, E., Borghini, G. \& Basch, V. (2018). Melt migration and melt-rock reaction in the Alpine-Apennine peridotites: insights on mantle dynamics in extending lithosphere. Geoscience Frontiers, doi: 10.1016/j.gsf.2018.11.001.

Renna, M. R. \& Tribuzio, R. (2011). Olivine-rich troctolites from Ligurian ophiolites (Italy): evidence for impregnation of replacive mantle conduits by MORB-type melts. Journal of Petrology 52, 1763-1790.

Renna, M. R., Tribuzio, R. \& Ottolini, L. (2016). New perspectives on the origin of olivine-rich troctolites and associated harrisites from the Ligurian ophiolites (Italy). Journal of the Geological Society, London 173, 916-932.

Renna, M. R., Tribuzio, R., Sanfilippo, A. \& Thirlwall, M. (2018). Role of melting process and melt-rock reaction in the formation of Jurassic MORB-type basalts (Alpine ophiolites). Contributions to Mineralogy and Petrology 173, 31.

Rosenberg, C. L. \& Handy, M. R. (2005). Experimental deformation of partially melted granite revisited: implications for the continental crust. Journal of Metamorphic Geology 23, 19-28.

Ross, K. \& Elthon, D. (1997). Cumulus and postcumulus crystallization in the oceanic crust: major and trace elements geochemistry of Leg 153 gabbroic rocks. In: Karson, J. A., Cannat, M. and Miller, D. J. (eds) Proceedings of the Ocean Drilling Program, Scientific Results, Vol. 143. College Station, TX, Ocean Drilling Program, pp. 333-350.

Saccani, E., Principi, G., Garfagnoli, F. \& Menna, F. (2008). Corsica ophiolites: geochemistry and petrogenesis of basaltic and metabasaltic rocks. Ofioliti 33, 187-202.

Sanfilippo, A. \& Tribuzio, R. (2013). Building of the deepest crust at a fossil slow-spreading centre (Pineto gabbroic sequence, Alpine Jurassic ophiolites). Contributions to Mineralogy and Petrology 165, 705-721.

Sanfilippo, A., Dick, H. J. B. \& Ohara, Y. (2013). Melt-rock reaction in the mantle: mantle troctolites from the Parece Vela ancient back-arc spreading centre. Journal of Petrology 54, 861-885.

Sanfilippo, A., Tribuzio, R. \& Tiepolo, M. (2014). Mantle-crust interactions in the oceanic lithosphere: constraints from minor and trace elements in olivine. Geochimica et Cosmochimica Acta 141, 423-439.

Sanfilippo, A., Morishita, T., Kumagai, H., Nakamura, K., Okino, K., Hara, K., Tamura, A. \& Arai, S. (2015a). Hybrid troctolites from mid-ocean ridges: inherited mantle in the lower crust. Lithos 232, 124-130.

Sanfilippo, A., Tribuzio, R., Tiepolo, M. \& Berno, D. (2015b). Reactive flow as dominant evolution process in the lowermost oceanic crust: evidence from olivine of the Pineto ophiolite (Corsica). Contributions to Mineralogy and Petrology 170, 38.

Sanfilippo, A., Dick, H. J. B., Ohara, Y. \& Tiepolo, M. (2016a). New insights on the origin of troctolites from the breakaway area of the Godzilla Megamullion (Parece Vela back-arc basin): the role of melt-mantle interaction on the composition of the lower crust. Island Arc 25, 220-234.

Sanfilippo, A., Morishita, T. \& Senda, R. (2016b). Rhenium-osmium isotope fractionation at the oceanic crust-mantle boundary. Geology 44, 167-170.

Sanfilippo, A., Tribuzio, R., Ottolini, L. \& Hamada, M. (2017). Water, lithium and trace element compositions of olivine from Lanzo South replacive mantle dunites (Western Alps): new constraints into melt migration processes at cold thermal regimes. Geochimica et Cosmochimica Acta 214, 51-72.

Saper, L. \& Liang, Y. (2014). Formation of plagioclase-bearing peridotite and plagioclase-bearing wehrlite and gabbro suite through reactive crystallization: an experimental study. Contributions to Mineralogy and Petrology 167, 985.

Scambelluri, M., Hoogerduijn Strating, E. H., Piccardo, G. B., Vissers, R. L. M. \& Rampone, E. (1991). Alpine olivine and titanian clinohumite bearing assemblages in the Erro-Tobbio peridotites. Journal of Metamorphic Geology 9, 79-91.

Seyler, M., Cannat, M. \& Mével, C. (2003). Evidence for major element heterogeneity in the mantle source of abyssal peridotites from the Southwest Indian Ridge $\left(52^{\circ}\right.$ to $\left.68^{\circ} \mathrm{E}\right)$. Geochemistry, Geophysics, Geosystems 4, 9101.

Soustelle, V., Tommasi, A., Bodinier, J. L., Garrido, C. J. \& Vauchez, A. (2009). Deformation and reactive melt transport in the mantle lithosphere above a large-scale partial melting domain: the Ronda peridotite massif, Southern Spain. Journal of Petrology 50, 1235-1266.

Soustelle, V., Tommasi, A., Demouchy, S. \& lonov, D. A. (2010). Deformation and fluid-rock interaction in the supra-subduction mantle: microstructures and water contents in peridotite xenoliths from the Avacha Volcano, Kamchatka. Journal of Petrology 51, 363-394.

Soustelle, V., Walte, N. P., Geeth, M. A., Manthilake, M. \& Frost, D. J. (2014). Melt migration and melt-rock reactions in the deforming Earth's upper mantle: experiments at high pressure and temperature. Geology 42, 83-86.

Suhr, G., Hellebrand, E., Johnson, K. \& Brunelli, D. (2008). Stacked gabbro units and intervening mantle: a detailed look at a section of IODP Leg 305, Hole U1309D. Geochemistry, Geophysics, Geosystems 9, 010007.

Takazawa, E., Frey, F. A., Shimizu, N., Obata, M. \& Bodinier, J.-L. (1992). Geochemical evidence for melt migration and reaction in the upper mantle. Nature 359, 55-58.

Tommasi, A., Mainprice, D., Canova, G. \& Chastel, Y. (2000). Viscoplastic self-consistent and equilibrium-based modeling of olivine lattice preferred orientations: implications for the upper mantle seismic anisotropy. Journal of Geophysical Research: Solid Earth 105, 7893-7908.

Tribuzio, R., Tiepolo, M., Vannucci, R. \& Bottazzi, P. (1999). Trace element distribution within olivine-bearing gabbros from the Northern Apennine ophiolites (Italy): evidence for post-cumulus crystallization in MOR-type gabbroic 
rocks. Contributions to Mineralogy and Petrology 134, 123-133.

Tribuzio, R., Tiepolo, M. \& Vannucci, R. (2000). Evolution of gabbroic rocks of the northern Apennine ophiolites (Italy): comparison with the lower oceanic crust from modern slow-spreading ridges. In: Dilek, Y., Moores, E. M., Elthon, D. and Nicolas, A. (eds) Ophiolites and Oceanic Crust: New Insights from Field Studies and the Ocean Drilling Program. Geological Society of America, Special Papers 349, 129-138.

Tribuzio, R., Thirlwall, M. F. \& Vanucci, R. (2004). Origin of the gabbro-peridotite association from the Northern Apennine ophiolites (Italy). Journal of Petrology 45, 1109-1124.

Tursack, E. \& Liang, Y. (2012). A comparative study of melt-rock reactions in the mantle: laboratory dissolution experiments and geological field observations. Contributions to Mineralogy and Petrology 163, 861-876.

Van den Bleeken, G., Müntener, O. \& Ulmer, P. (2011). Melt variability in percolated peridotite: an experimental study applied to reactive migration of tholeiitic basalt in the upper mantle. Contributions to Mineralogy and Petrology 161, 921-945.

Van der Wal, D. \& Bodinier, J.-L. (1996). Origin of the recrystallization front in the Ronda peridotite by $\mathrm{km}$-scale pervasive porous melt flow. Contributions to Mineralogy and Petrology 122, 387-405.

Vissers, R. L. M., Drury, M. R., Hoogerduijn Strating, E. H. \& Van der Wal, D. (1991). Shear zones in the upper mantle: a case study in an Alpine Iherzolite massif. Geology 19, 990-993. 